\title{
Texts in Chaghatay
}


Paolo Sartori and Ulfat Abdurasulov - 9789004427907 Downloaded from Brill.com04/26/2023 09:59:36AM via free access 


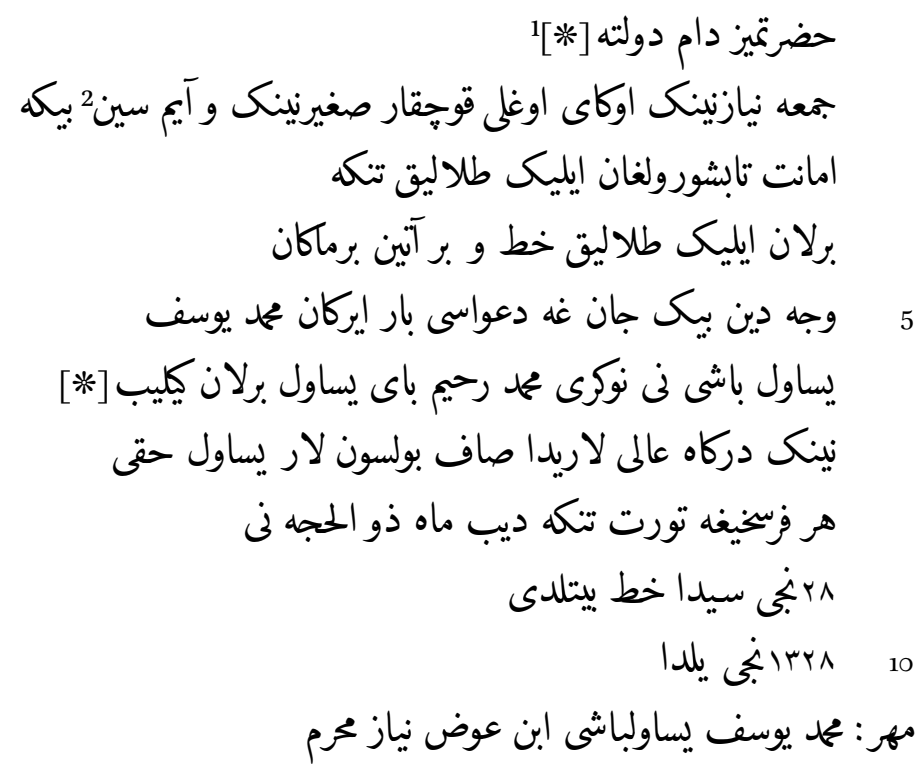

[verso]

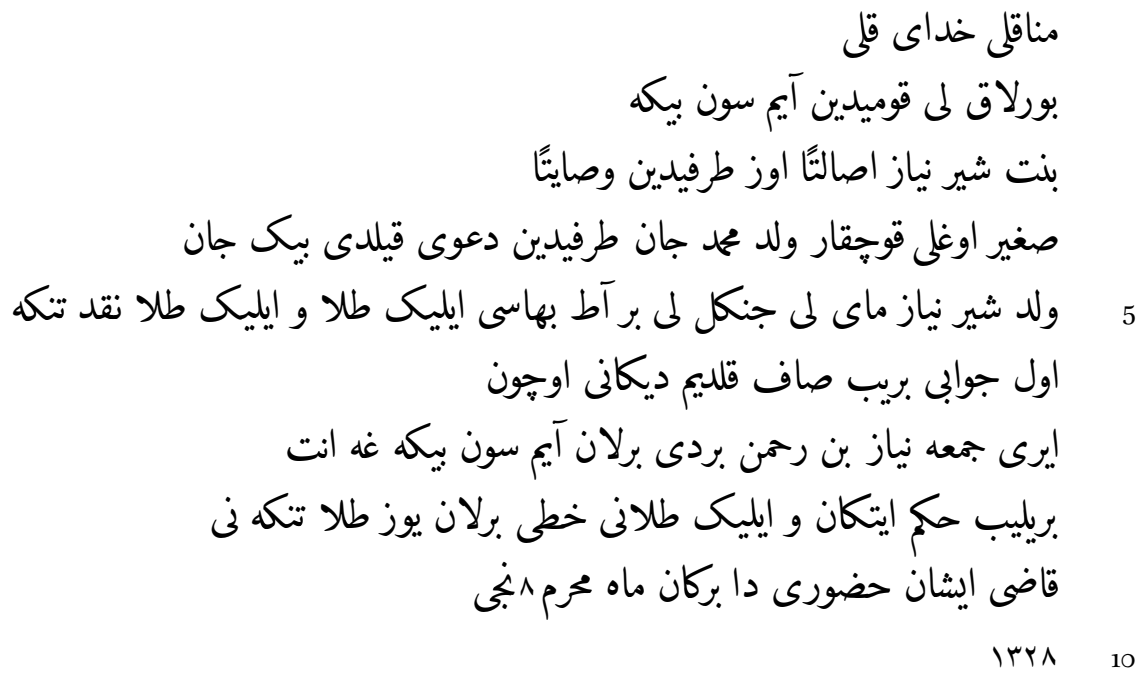

1 The sign * refers to expressions which in the original version of the document are written outside the body of the text and are cross-referenced. Conventionally, such expressions appear at the top of the document; thus we have placed them at the beginning of the text.

2 This is a textual variation of آيرسون, see below verso side.

(C) PAOLO SARTORI AND ULFAT ABDURASULOV, 2020 | DOI:10.1163/9789004427907_007

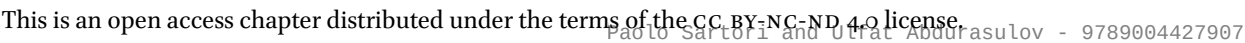




\section{Document 2}

حضرتميز دام دولته [*]

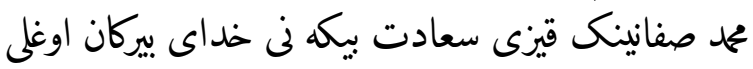

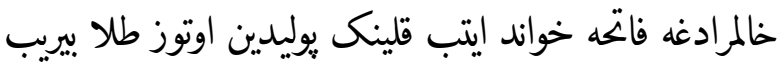

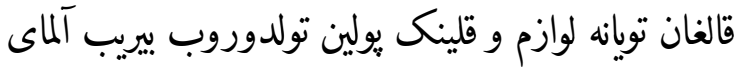

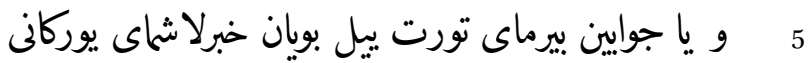

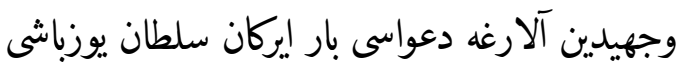

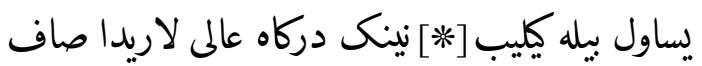

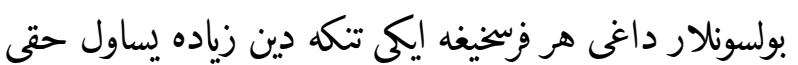

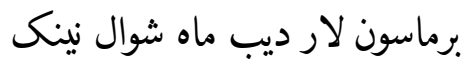
10

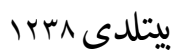
مهر: شيخ نضر يساولباشى ابن محمد مراد ديوان بيكى لئنى [verso] مناق دا ايش نياز باجبان قوميدين

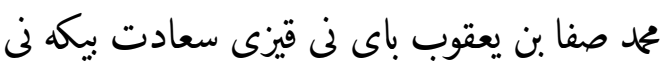

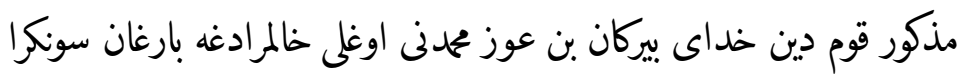
طوى ايتب برماك بولغان قالينك مالى نى اليب بولغان ايمدى توزوك لباس لان لارى بيله 5

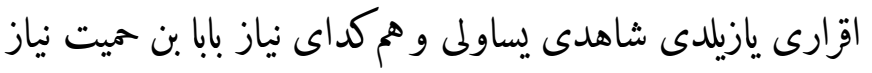




\section{Document 3}

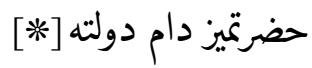
مروّج شريعت نبوى قاضى عسكر ايشانمينينك معلوم دور لارى بولغايكيم

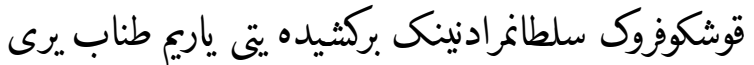

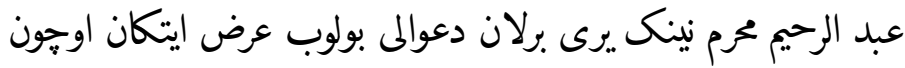
5

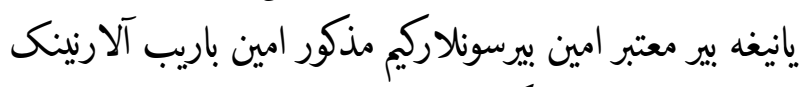
قوليداغى خط لارين كوروب دعوالى يرلارين شريعت بيرلان

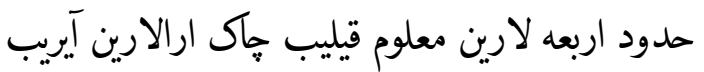

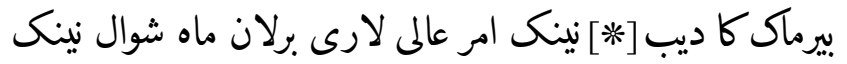
10

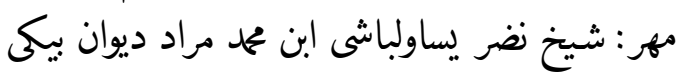

[verso]

$$
\begin{aligned}
& \text { اوز حديميزدا توردوق ديب معلوم قيلدى لار امين }
\end{aligned}
$$

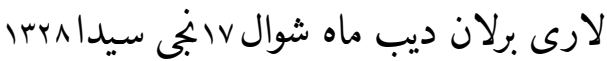

$$
\begin{aligned}
& \text { قاضى دين قوشولغان امين ملا تاجى داه تشوال }
\end{aligned}
$$




\section{Document 4}

حضرتميز دام دولته [*] ابراهيم نينك قالينك فولى و لباس و توزوك لارين دين بريب بولغان فاتحه خواندى خدييه بيكه ني لينا نكاح ايتب برماكان لارى وجهيدين 5 اوراض محمج برلان رمضان لارغه دعواسى لمانى بار ايركان شيخ نظر يساولباشى نينك

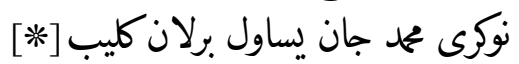

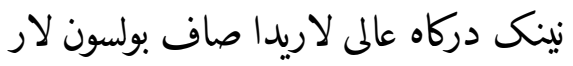

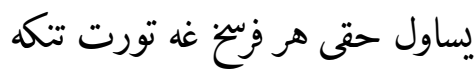
10 بتلدى ^بسائمى يلدا مهر: محم يوسف يساولباشى ابن عوض نياز محرم [verso] ماه مخرم نينك يتى سيدا ابراهيم بن

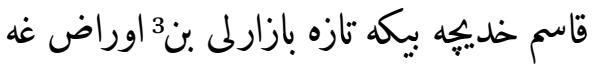
مذكور بولغان دعواسين شريعت دا بركان فوليكه

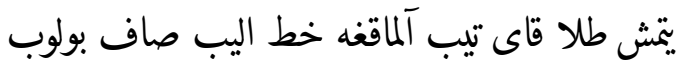
5 5

3 sic; clearly should be بنت. 


\section{Document 5}

حضرتميز دام دولته [**] ماليل جنكل للى اوراضباى نينك خيوه قلعه لى إشمراد ديكان دين

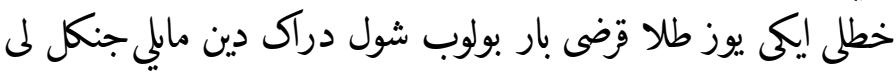

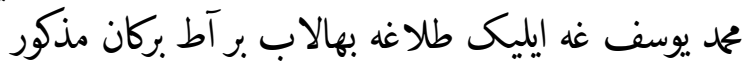
5 مذكور بركان لارى نى حساب ايتاى خطلى ايكى يوز طلانى آلغانى

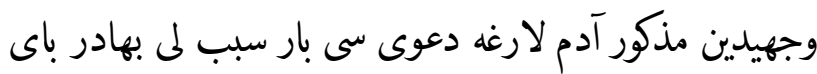
ايشيك آقاسى نى نوكرى رمنقلى يساول بيله موندا دركاه

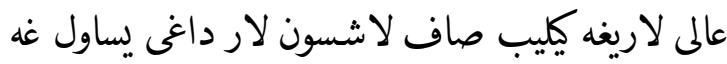
10

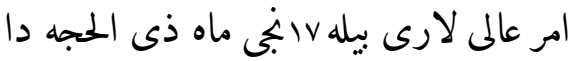
خط ييتلدى ^rrانئ يلدا مهر: شيخ نضر يساولباشى ابن محمد مراد ديوان بيكى يلمى بلى

[verso]

$$
\text { اوشبو دعوى نى شريعت غه قوشولوب }
$$

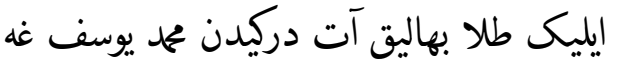
آنت بركان و مذكور ايشمرادغه اوتوز طلا دعوى سين شريعت دا اشيتلهاى صاف بولوب 5 جيقدى ذو الحجه بrنجى 


\section{Document 6}

حضرتميز دام دولته [*]

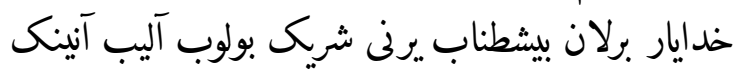

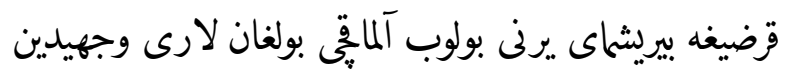

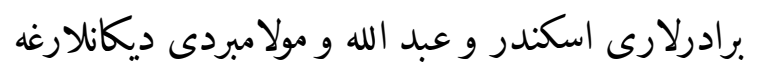

5

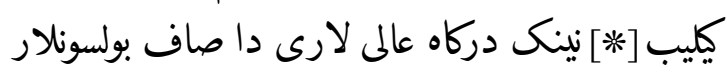

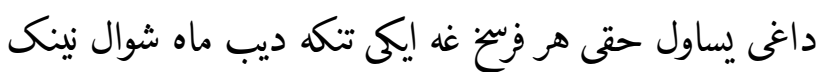
vلانجى سيدا اوشبو خط مرقوم بولدى یبrا الانجى يلدا مهر: محمد يوسف يساولباشى ابن عوض نياز محرم

[verso]

شيرشالى لم ملا خدايار حافق داغى خدايارنينك

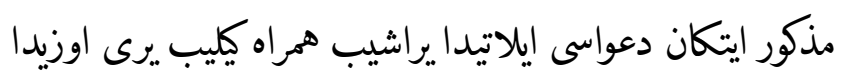

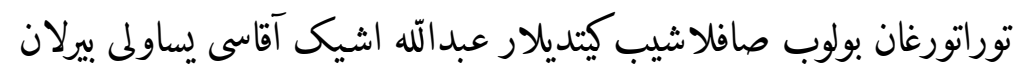
كيليب معلوم ايتدى توران بوري 


\section{Document 7}

حضرتميز دام دولته [تمان

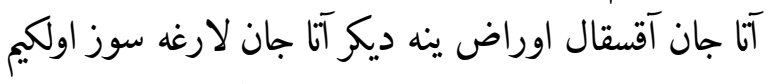

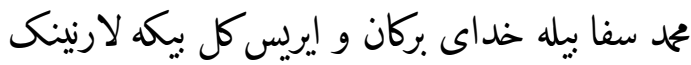
دعوى لارين اصل واقعه لارين تحقيقلاب سوراشيلمات 5

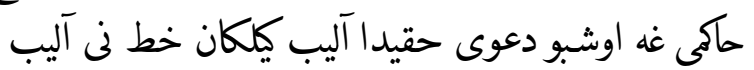

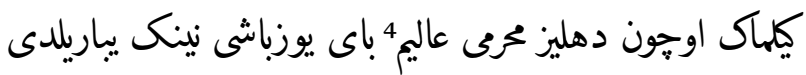
ايمدى خط كوركاج مذكور آدم لار مذكور يساول بيله موندا دركاه عالى لاريغه يكليب بِان واقعه لارين آيتسون لار ديب [**] نينك امر عالى لاري لارى بيله 10

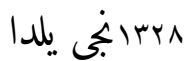
مهر: شيخ نضر يساولباشى ابن محمد مراد ديوان بيكى يلى [verso] شوال r r بو خط هم يساول لى يتك غه داخل واقعه سينى آنكه يازيلدى 


\section{Document 8}

حضرتميز دام دولته [*] سرشالى لى محمد يعقوب نى قاين آتاسى ايش نياز اولوب آندين تخمينًا اوج ياريم طناب ي

و بير حولى قاليب آنى قض لارى اوجون ساتيليب شول يرنى اوزى ايكى يوز طلا

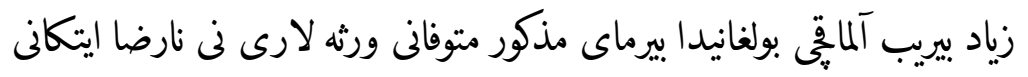

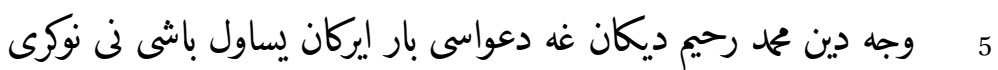

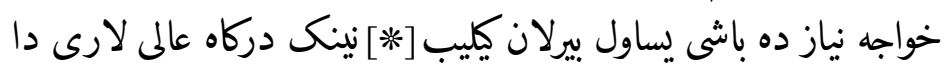

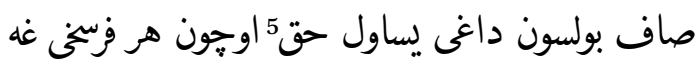

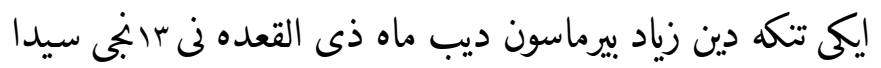
خط بتيلدى 10 مهر: محمد يعقوب يساولباشى ابن محمد يوسف يساولباشى

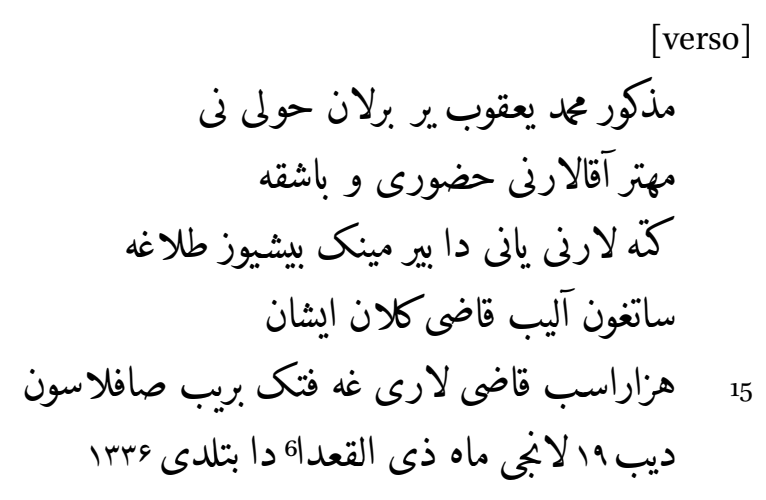

6 Textual variation of ذى القعده. 


\section{Document 9}

حضرتميز دام دولته [*] بيش آريقلى قيلج نيازغه يتى ياريم طناب يرنى مينك دون طلاغه ساتيب

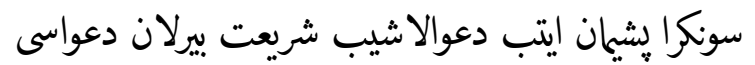

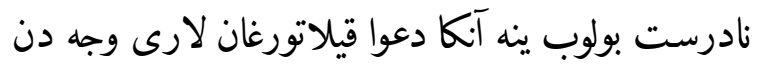
5

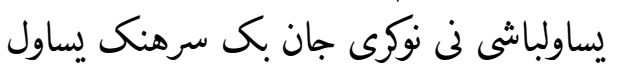

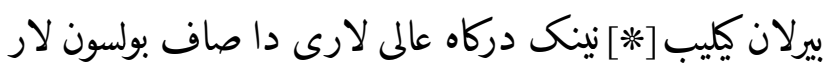
داغى يساول حق7 هر فرسيخه إيكى تنكه ديب انبى ماه

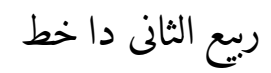
10 مهر: محم يعقوب يساوباشى ابن محم يوسف يساولباشى برى

[verso]

مذكور قيلج نيازنى دعواسى شرايته غه قوشولوب مسئله آليب

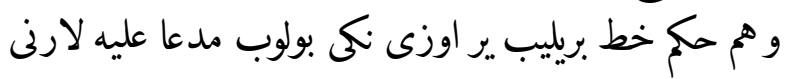

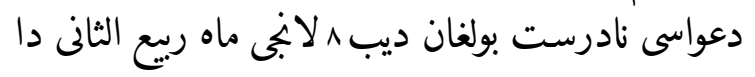
Irrg

8 Textual variation of شريعت. 


\section{Document 10}

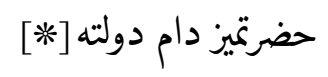

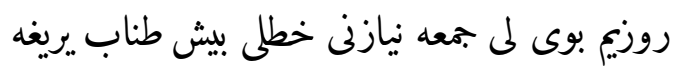

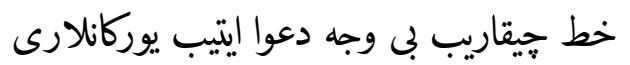

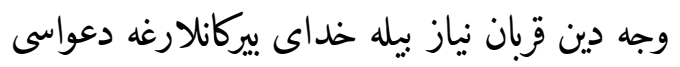

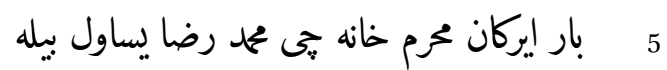

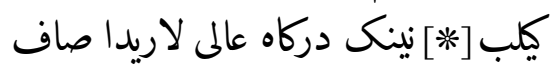
بولسون لار داغى يساول حقى هر فرسخيغه

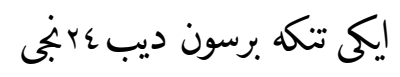

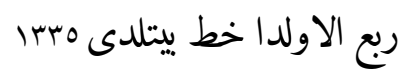
مهر : محم يوسف يساولباشى ابن عوض نياز محرم [verso]

مذكور مدعى روزيم بوليل مسجد بالتاق ميراب دا

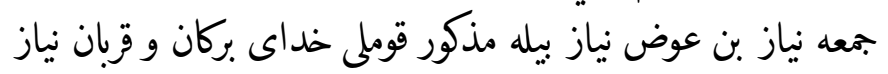

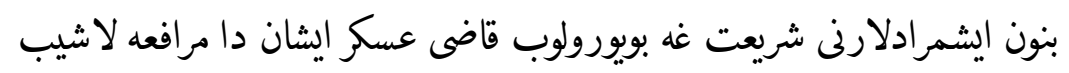

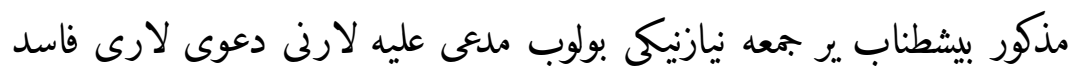

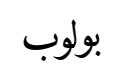

5 خط ابراءلاشيب صاف لاشديلار ديب 9rبنى ماه ربع الاولداهrrا 


\section{Document 11}

حضرتميز دام دولته [*] شريعت شعار ديانت آثار قاضى ايشانيميزغه اعلام اولكيم

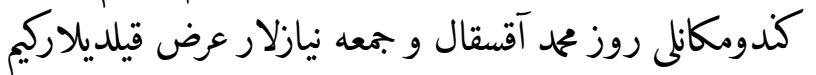

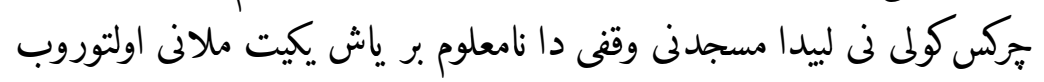
5

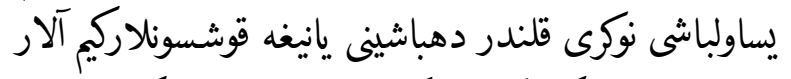
همراه باريب مذكور آقسقال كدخد الارى بيله مذكور

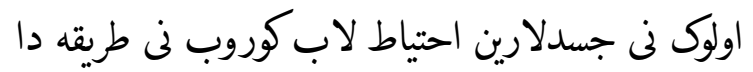

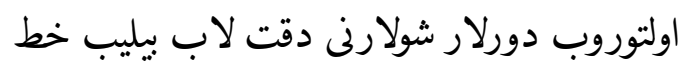
10

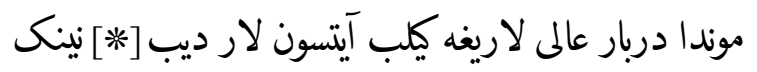

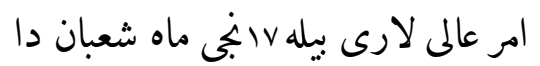
خط بيتلدى وبسابنى ييلدا

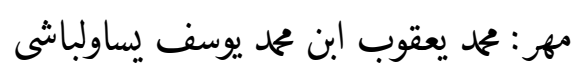

[verso]

مذكور اولوك نى قاضى ايشان نن آدى محمد شريف خواجه

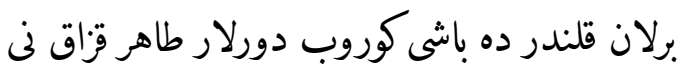

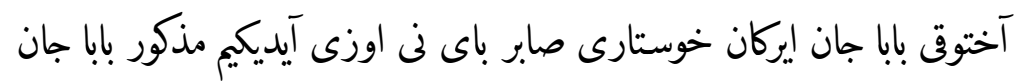

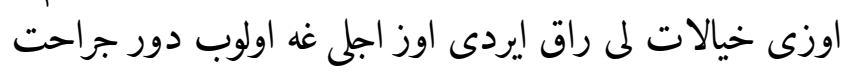

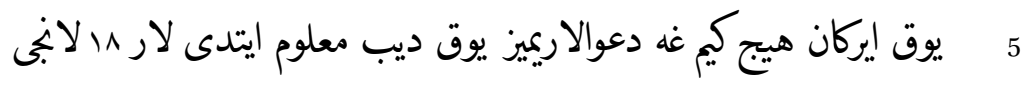
ماه شعبان داوبها 


\section{Document 12}

سعادت يناه و حكومت دستكاه يساول باشى آقاميزنينك جناب عالى لاريغه عرض و اخلاصميز بوكيم بومير يلي قبان باى دئي ديكان عرض ايتب محمج يوسف يساول باشى آقاميزينيك

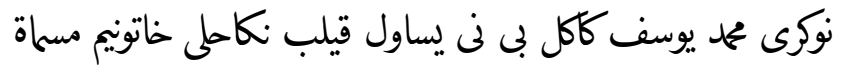

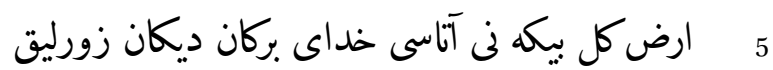
قيلب برمايدور ديكان عرضى بيله و خداى بركان بران

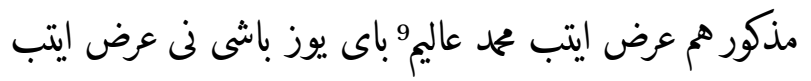

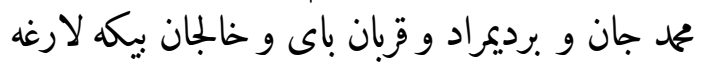
عاليم10 باى يوزباشى مذكورنى يساول قيلب مذكور آدمانلار 10 نينك عاجز و بيحاره بولغانليقى وجهيدين خذمتلاريغه ارسال قيلندى ماه شوال

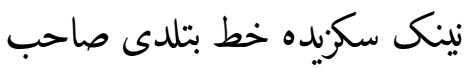
اختيار اوزلارى تورورلار

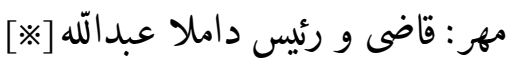
قاضى و رئيس داملا الله بركان [تجان 


\section{Document 13}

وزير الكرام يساولباشى آقامنينيك خذمتلاريغه معروض اولمي

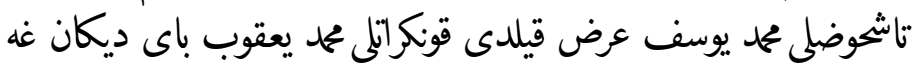

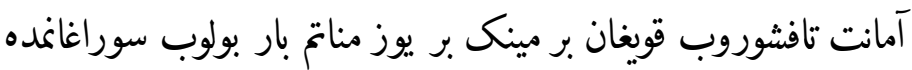

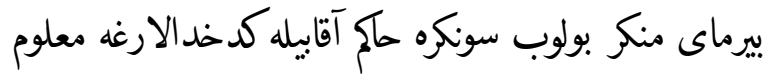

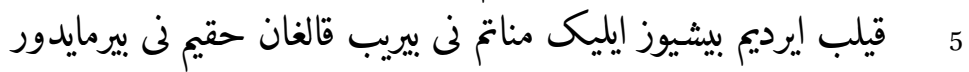

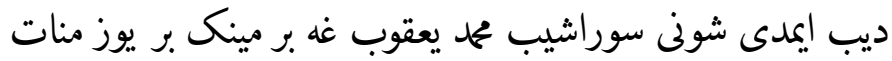

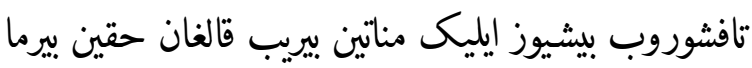

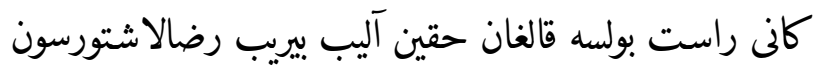

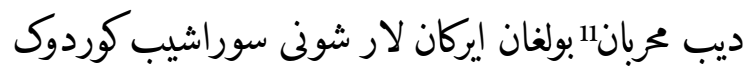
10

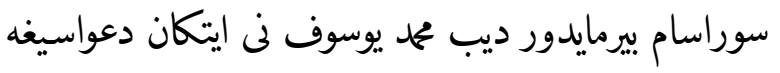

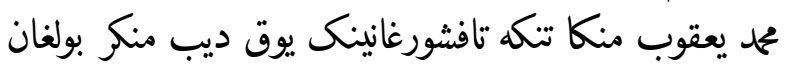

[verso]

بولغانيدين سونكره قاضى ايشان لارغه قوشولغان إيركان سونكره

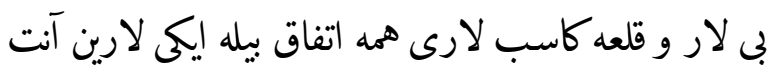

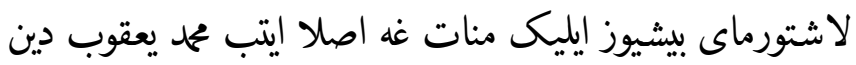
15

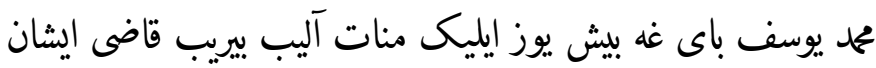

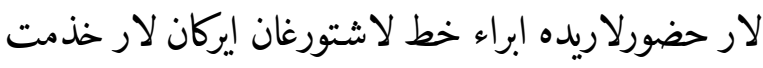

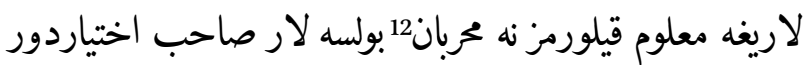

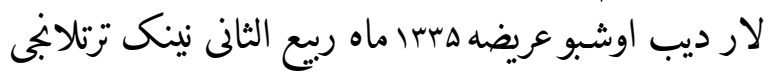

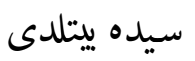

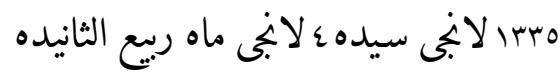

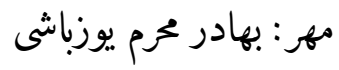

11 Textual variation of مهربان.

12 sic. 


\section{Document 14}

عزت نشان يساول باشى آقانينك معلوم لارى بولسونيم قرق يافلى

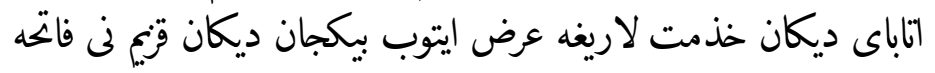

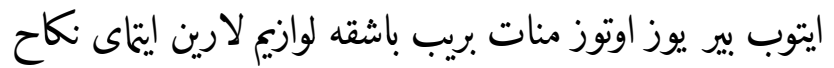
ايتاكيى تورور ديب يساول كيلتوركان ايركان شول سببلى موندا

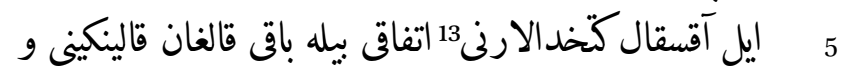

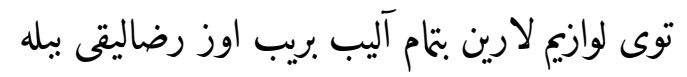

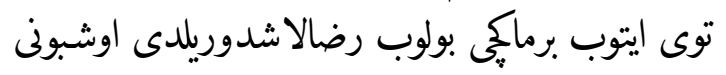

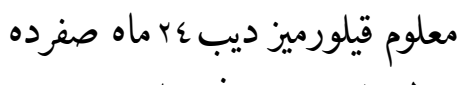
خط بتلدى عبها انجى يلده مهر : محم يعقوب باى ابن [جبار قلى مرزمج

13 Textual variation of كدخدا. 


\section{Document 15}

عزت نشان يساول باشى آقانى معلوم لارى بولغايكيم تمه لى

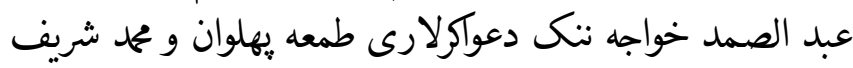

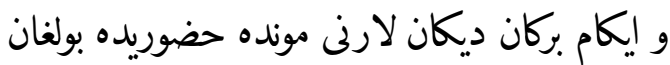

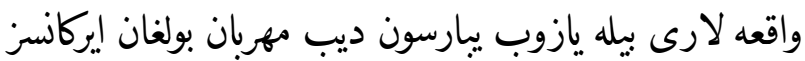

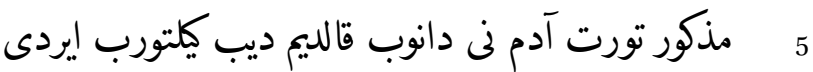

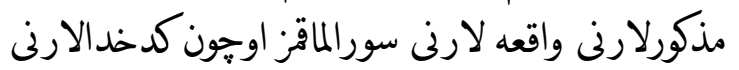

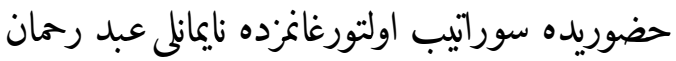

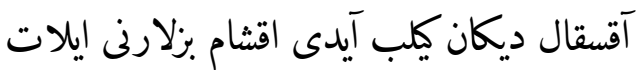

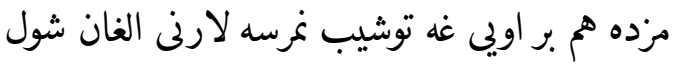
10

[verso]

ديب آيغان حالى ده مذكورلارنى كدخدا آقسقال لارى

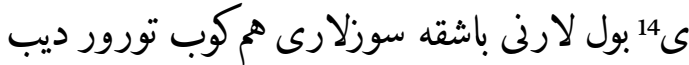

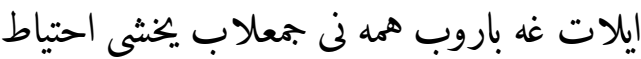

$$
\begin{aligned}
& \text { ايتب بارلاشيب كيكتورورميز ديب آليب }
\end{aligned}
$$

15

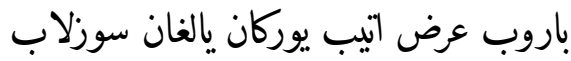

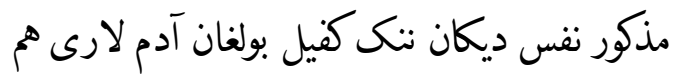

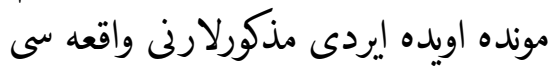

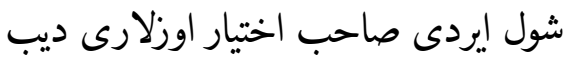

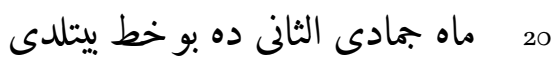

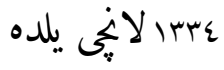
مهر: محمد يوسف باى ابن يهلوان مرم 


\section{Document 16}

وزارات بناه حكومت دستكاه يساولباشى آقاميزينك خذمتلاريغه معروض اولمي اوشبو ماه ماه15 ريع الاولده نياز بيكه ديكان كفغ يكليب معلوم قيلدى قيريخ سعادت بيكه نى إيى يخشمرات ديكان اوروب ثمرو 16 ايتب قاجيب كتدى ديب شول توغريده شريعت شعار

كورلان قاضى ايشان لاريدين بي امين آيب آيل كدخدالارى نن يغناب آلار هم 5 امين بيله مذكور ناهجارنى كوروب كدخدالارى بيله يكليب صورات17 واقعه ني معلوم قيليب إيردى لار ايمدى ليكدا مذكور يخشمرات ديكان نكاحلى خاتونوم آناسينى

كيب إيردى Tكاسى منكا قوشوب يارمايدور ديب عرض ايتكان سبلى شول عرضى راست بولسه خاتونين إيغه قوشسون باشقه سوزى بولسه شريعت بيله بيتكارسون

بولماسه.

موندا قوشوب يارسون ديكان بويروق عالى لا ريغه موافيق 18 آلارنى موندا يرا

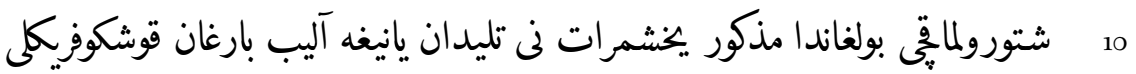

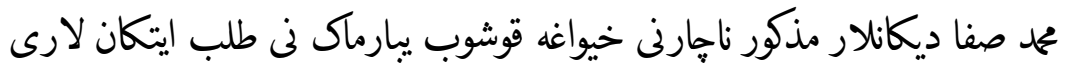
سببلى آقسقالى خالمرات غه قوشوب جنابنكيزغه يباريلدى اوشبو بيان بولغان لارنى معلوم ايتسانكز ايركان ديكان نياز بيكه كفرنى التاسيغه كورا تياق يكان ناجهارنى كوركان امين لارنى بيان ايتكان لارينى ازبراى جنابنكيزغه معلوم قيليب 15

[※] : مهر

15 Repeated word.

16 Textual variation of بجروح.

17 Textual variation of صورت

18 Textual variation of مورتّ. 


\section{Document 17}

وزارت فناه19 نجابت دستكا محمد محرم يسوباشى اقانينك

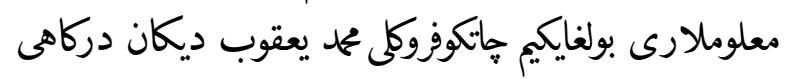

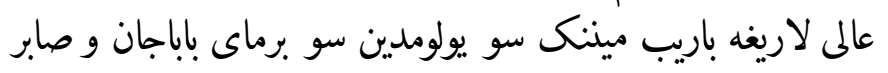

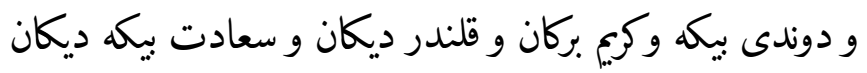
5

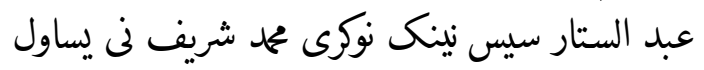

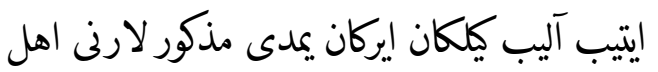

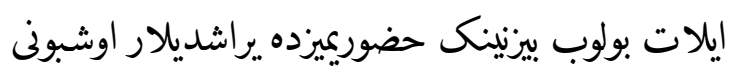

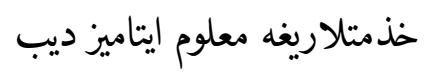
10 irta مهر: الله بركان باى ابن عوض نياز مرم

19 Textual variation of يناه. 


\section{Document 18}

وزارت فناه20 ساولباشى آغاميزنينك خذمت لاريغه معلوم لارى

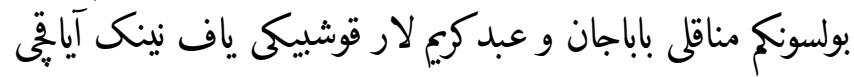

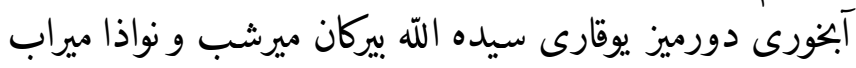

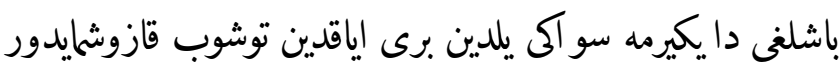

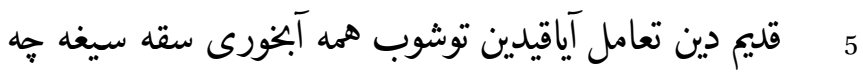
قازوشاق إيردى ديب مذكورلارنى سوراشب قاشي قديمدين

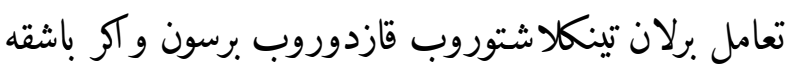

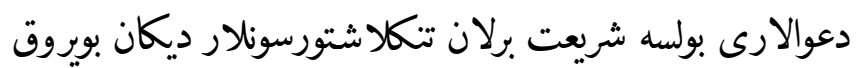

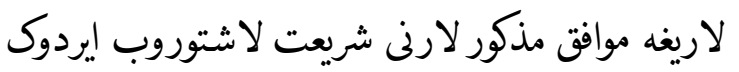
10 تورورلار ارضه كوى كواه اوتكارماكيكى بولغانده خيواغ إنها

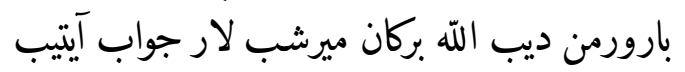

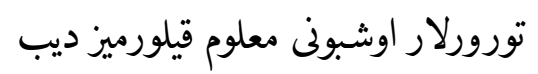

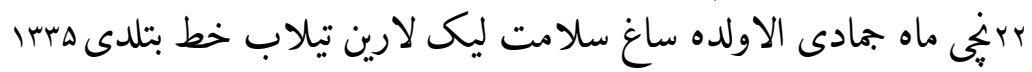

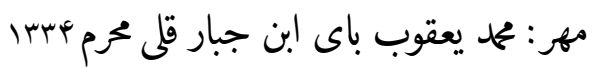




\section{Document 19}

وزير اعظم دستور المكرم أعنى يساول باشى آقه ميزنينك

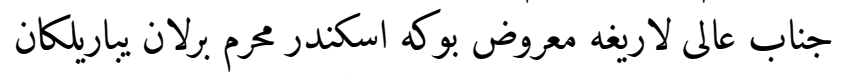

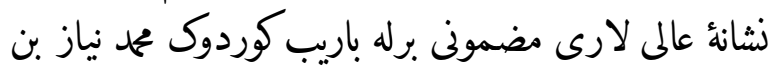

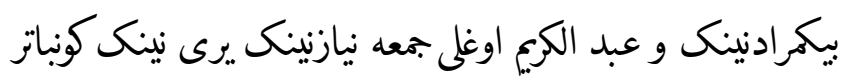

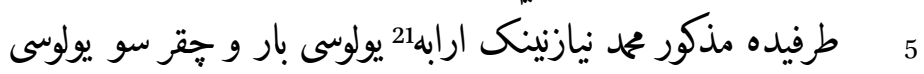

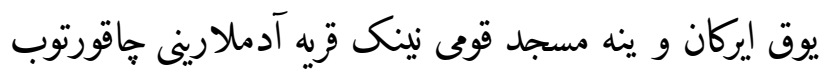

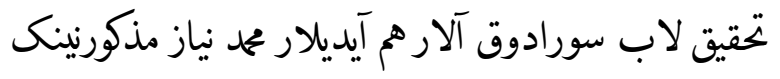

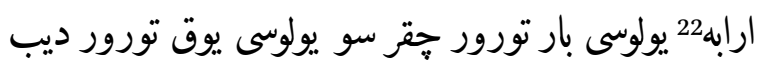

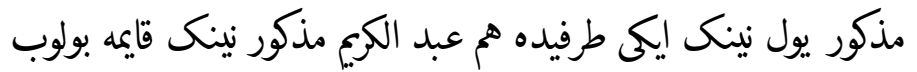
10

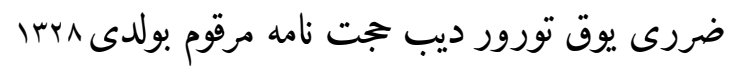

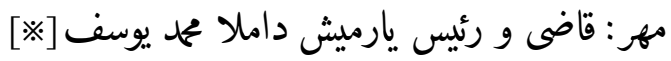

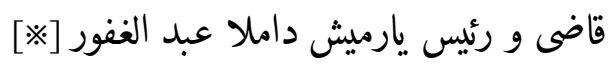

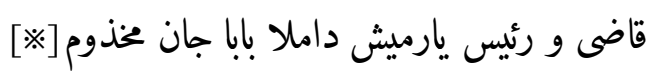

21 Textual variation of عرابه.

22 sic. 


\section{Document 20}

وزارة يناه حكومت دستكاه يساول باشى آقانيتك

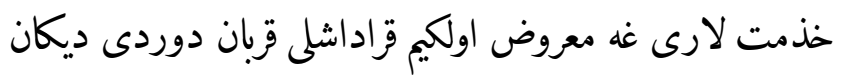
دربار عالى لارى غه عرض ايتب نيشانه يكلتوردى قينيم

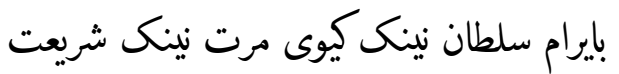

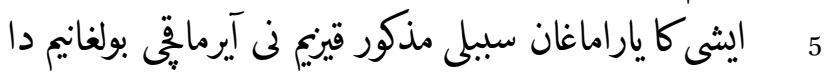

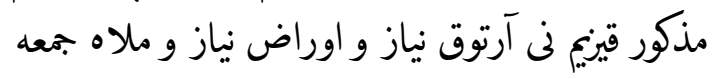

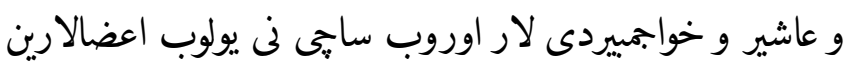
جراحت دار ايتب منكا خوارليق بيردى لار ديب ديب

[verso]

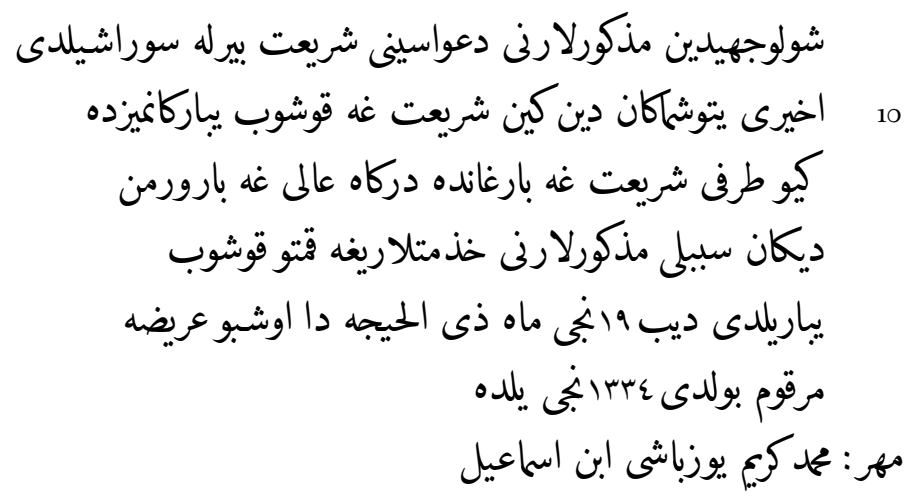




\section{Document 21}

$$
\begin{aligned}
& \text { وزارت يناه حكومت دستكاه يساويل23 باشى آقاميزغه } \\
& \text { معلوم و هويدا بولغايك محم كزيم يوزباشينى آدمى صالح }
\end{aligned}
$$
آلتى يوز منات بر ياريم باتمن بوروبج حقيم بار و ينه ملا بكان عجاندا 5

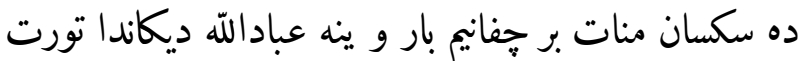

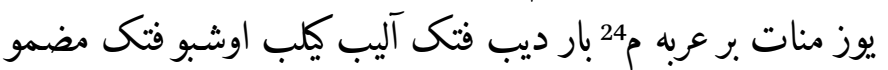
نيدين آكاه بوليب مذكور آدملارنى هاقيب موريب سوراغانميزده

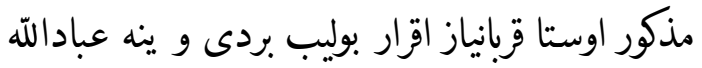
10 يوقديب اقرار بولدى اوشبو آكى يوز قرق منات نى آليب

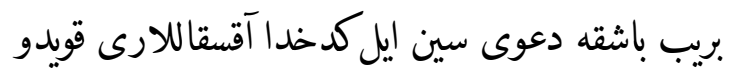

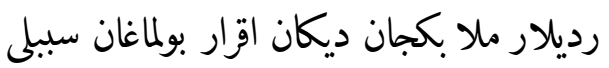
شريعت غه قوشدوق شريعت بيله صالح ديكان كواهغه توشيب ملا بكجان آنت غه كيلب دور آندين سونك فريك

$$
\text { قاضى ايشان آيتب تورورلار من سيزلارنى مرافيعهان }
$$$$
\text { نكزنى سورامايمن تور كيت ديدور مذكور ملا بكجان }
$$

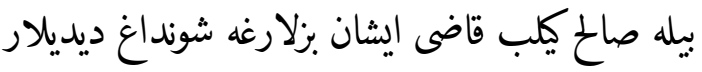

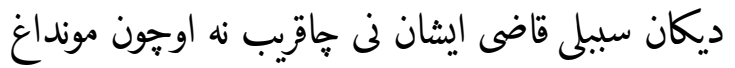

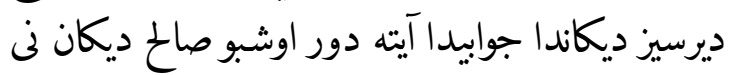

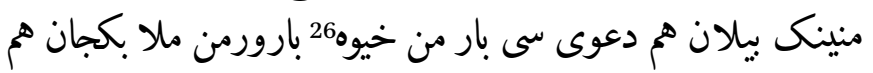

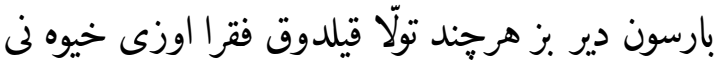

23 Textual variation of ساول.

24 Textual variation of عرابه with the first-person singular possessive suffixe

25 Textual variation of مرافعة

26 Suffix غه is clearly missed here. 
طلب قيلماسه إيكى يوز منات باريب كيلكونهه خرج بولور و ينه شريعت فومايشى بيله صاف بولسون ديكان مهربانيلت

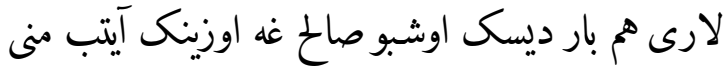
اوستمكا فتك آيب كيلب دور ديب توريب كيتى

[verso]

اوشبو واقعه سببلى مذكور ملا بكجان بيله قاضى ايشان نى

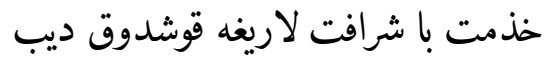

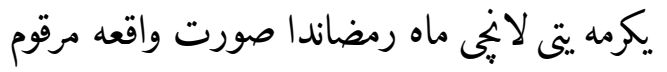
30 مهر : خواجه نياز باى ابن عبدالله مرم هبrا 


\section{Document 22}

وزرات يناخ2 حكومت دستكانه يساولباشى آقانينك معلوم لارى بولغايكيم قره تاليلى

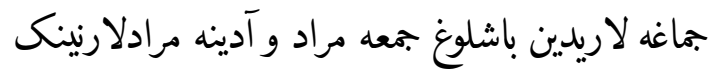

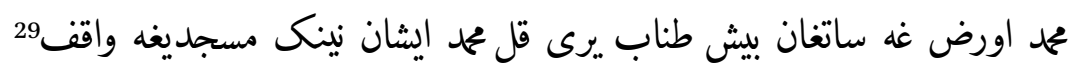

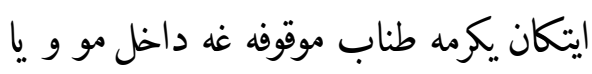

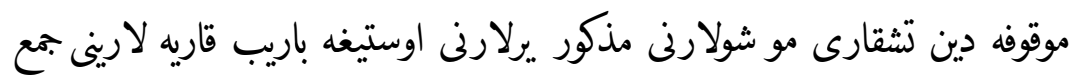
ايتب سوراشيب بيان واقعه لارينى موني مونده معلوم ايتسونلار ديكان بويروق لاريغه موافيق 30 مذكور يرنينك اوستيغه باريب تابعى مذكورنى قاريه لارينى جمع ايتب لئب

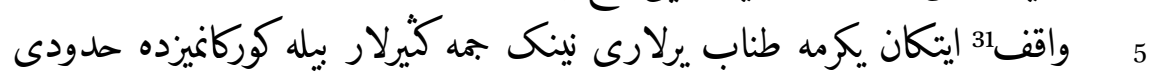

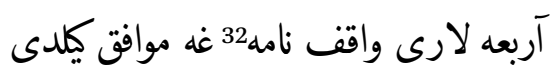

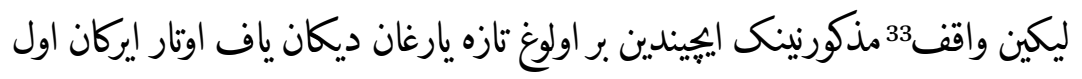

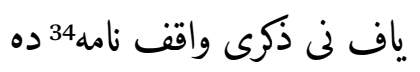

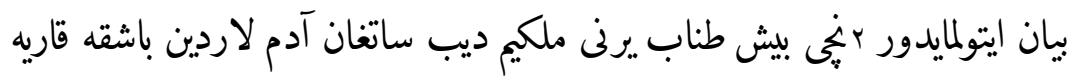

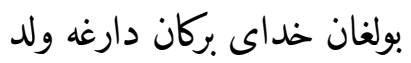
صفر نياز و محمد يناه دارغه ولد احمد و سيد نياز ولياز ولد صفر نياز ديكر و جمعه نياز ولد

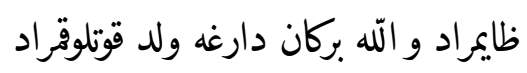

و خالمراد ولد سيتك و بهلوان نياز ولد التانياز و خالمراد ولد قوشمان وخداى براد بركان

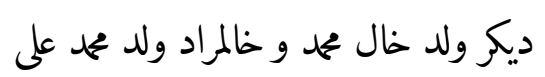

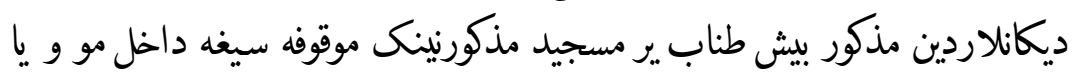
10

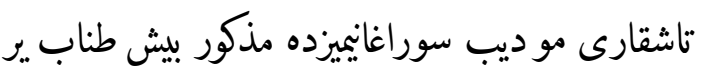

\footnotetext{
27 Textual variation of

28 Textual variation of دستל

29 Textual variation of دق 28.

30 Tوافق Thtual variation of.

31 sic.

32 Textual variation of وقف 33.

33 sic.

34 sic.
} 
ساتغان آدملارنى حقى و ملكى دور واقف35 غه داخل إيراسدور ديكانلارى

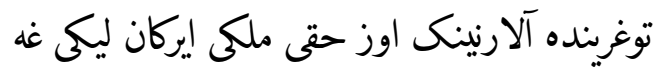

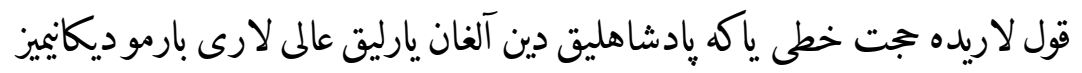
ده تابه مذكورنينك بر يكى مرتبه سو آليب

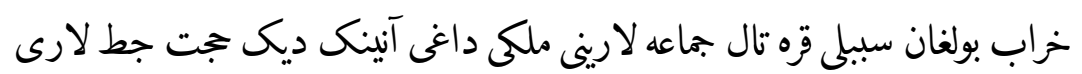
شول آندا يوق بولوب كيتكاندور مذكور واقق

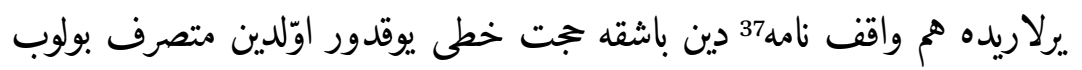
اولتورغان ملك لارى دور و آك ساتيلغان

15 نينك آيتاساق بو دنيا و اخزتده ضهانى

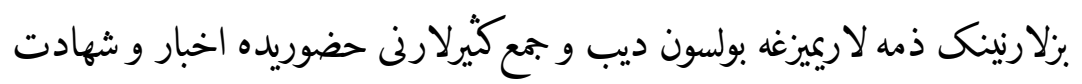

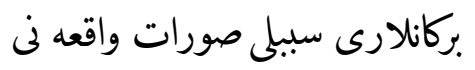
جناب لاريغه معلوم قلدوق ايمدى صاحب اختيار اوزلارى بيلورلات وإِ ديب هسبا

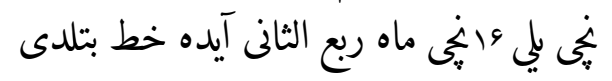

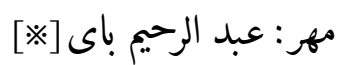

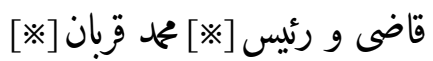

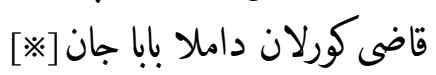

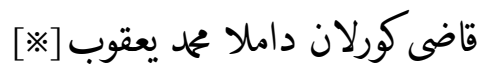

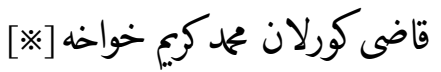

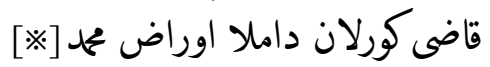




\section{Document 23}

وزارت فناه40 حكومت دستكاه يساول باشى اقاميزنى خذمتلاريغه معلوم بولغايكم شاه اباد

موضعيداغى ملا يوسف اقسقال نينك قوميداغى حق محمج بيله شريف ديكانلار

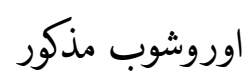

شريف اولكان سبب لى الارنينك دعوالارينى سوراشيب شول طرفده شريعت

فومايشى بيله

سافلاشتوروب بلهي آخين مونده بيلدورسون ديكان بويروغلارى نينك توغروسيده مذكور اولكان

5

خاتونى مساة قربان بيكه

و برادرلارى رجب باى و ملا ايشباى ديكانلاردين مذكور ورثه لارى آيديلار شريف مذكور وقت وتب موتيدين اوج كون اوّل اوروشوب ايردى اندين هم اوّل كسل ايردى بزلارنينك حق محمج

ديكانغه دعواميزنى اوتدوك ديب اقرار قليب كينديلار اندين سونكره مذكور شريف نे اوغلى جمعه نياز ديكان نى اوز طرفيدين اصل ايتب اناسى قبان بيكه مذكوره نى طرفيدين ويل بولوب كواهلارى مذكور يوسف اقسقال و رجب باى لارنينك شهادتى بيله الارنى موت اوتكانين شاه اباد قاضى ايشانلارين خط لاشتوروب مذكورلارنينك دعوالارين اوتوب خط لاشغانين خذمتلاريغه وبرانبى يلده ماه شعبان نينك يكمه يتى سيده صورة واقعه ني بيتب يباريلدى مهر: محمد صفا آتاليق ابن عبدالته آناليق

40 sic. 


\section{Document 24}

وزارت يناه يساولباشى آقانينك معلوم لارى بولسونيم هزاراسب لى ملا دوست و تاجى باى ديكان نوكلار باريب

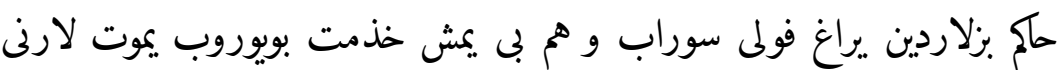
خراجاتى اوجون اون مناط

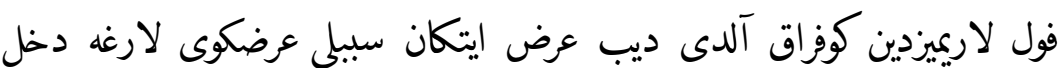

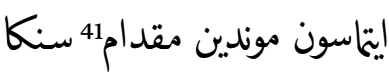
اوج تورت مرتبه فتك يباريلدى عمل ايتاى سن ايمدى موندين سونكره بو طريقه ايتسانك سنى حاكم ليكدين 5 يراغ توغريسيده كيلكان بويروق لارنى باى لار و آقسقال لارنى يغناب اعلام إيكايمزدا آلار

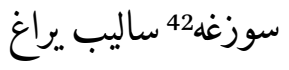
خذمتلارينى اورون غه كيلتورماك نى اتفاق إيكان لارينى محمح رحيم باى بيله جناب همايون لاريغه معلوم ايتوب ايردوك انينك بعديندا ينه قدارتلى آدام لاردين ايتاقغه بويرق بوليب

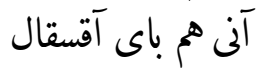
آقسقال43 لارغه اعلام ايتكانيميزدين سونك هر مسجد قومى نينك آقسقالى قدارتلى آدالى

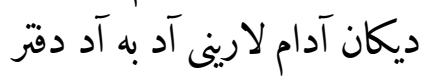

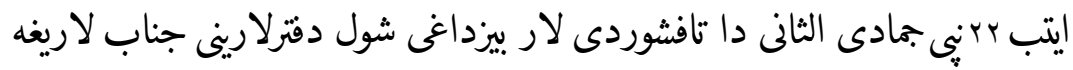
10

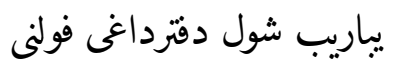
اوندوروب آلسون ديب بويروق بولغاندين سونك يراغ فولى فئى ني اوندوبوب برينك ديب آقسقال لارغه

41 Textual variation of مقدم.

42 In text: سوغه.

43 Reapeted word. 
بويوردوق شول آنغه جه نوكرلاردين و غريب فقرادين يراغ فولى سورالغانى يوق عرضكوى لارنى آلغان فتك لاريدين هم خبريميز يوقدور آلارنى فتك آلغان لينى نى محم امين ديوان بابادين ايشوتوب عرضكوى لارنى فئن آلدوروب سوراشوب فتك ني كوروب سيزلاردين كيم يراغ فولى سورادى لئ

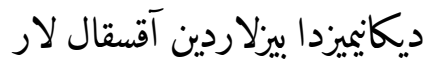

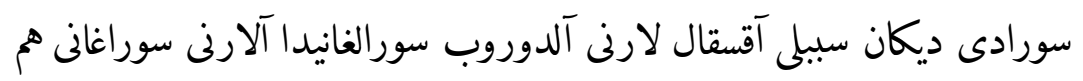
15 بيكار بولدى فتك ني نهون آلغان وافتيده يكل توروب بيرماى سيزلار ديكانميزدا يراغ فولى سورالسه بيرماكى

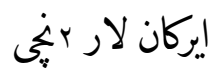

[verso]

يموت لارنى خراجاتى اوخون خهه مناط دين بيركان بولسه لار ايساعلخواجه حاكم وقتيده آلغان دور بيز يكل كاينيمزدين بيان يموت خراجاتى ديب نوكرلارغه و غريب فقراغه تازه دين جقون سالغانى يوق ايساعيلخواجه نى حآك واقتيده نوكرلا رنى بيركان فول لارينى يوزباشى لار بيزغه معلوم

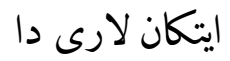

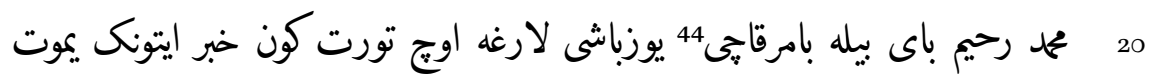

$$
\text { لارغه باى لارنى إيكان }
$$

خراجاتى بيله ايلدين يغناب آلغان فول لارينى حيسابى كورولسون آكرده آرتغان فولى لإنى بولسه نوكزلا رغه بيريلسون و آكر آرتماسه خذمتلاريغه سيزلارنى عرضينكيننى معلوم ايتوب نى ني

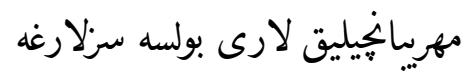
ينه معلوم ايتارميز ديب إيردوك آندين باشقه سوزلارى ديك دين خبريميز يوقدور عرضكوى لارنى حآك

44 Obviously a distorted rendering of بارماتى. 
258

TEXTS IN CHAGHATAY

بيزلاردين يراغ فولى سوراب بي يمش خذمت بويوبوب يموت خراجاتى اوحون فول

آلدى ديب يالغان دين

ديل كوركازيب ايتكان عرضلايني يوزباشى لاريدين و هم فتك نى يكل توروب

25

بيرماى اوزيميز

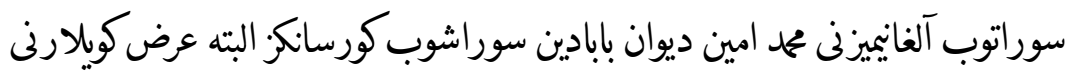

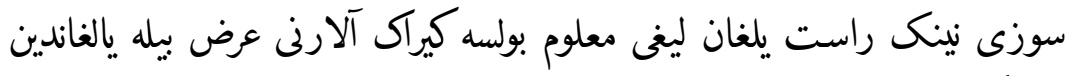
ديلكوركازيب

عرض ايتب يوركان ليكى نى ازبراى جناب همايون لاريغه معلوم قيلدوق ينه

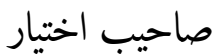

اوزلارى يخشى بيلورلار ديب ماه جمادى الثانى نينك اخيريدا عريضه احلاص

مرقوم

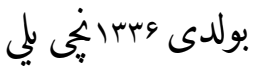

30

مهر: عبد الرحيم باى ابن محمكيم باى باى

Paolo Sartori and Ulfat Abdurasulov - 9789004427907

Downloaded from Brill. com $04 / 26 / 2023$ 09:59:36AM

via free access 


\section{Document 25}

وزارت ينا45 محم يوسف ياسول باشى آقا ميزنينك خذمت لاريغه معروز46 بوكيم يادكار

خواجه ني مسجد قوميدين عبد الله خواجه ديكان يكليب مونده معلوم قيلدى اويومكا خوفنان

وقتى مسجديمينينك امامى ملا خالباى بيلان اولتوريب إيرديك قافوم نى قاقتى لار

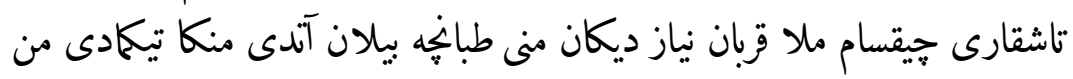
قاهديم آنام اولوغ جان بيكه كيليب ايردى ايكنجى مرتبه آتدى اوق آنام نى كوكراكيدين كيبب

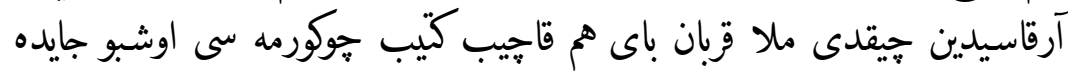
قالدى

اوق بله جوكورمه نى كيلتوروب كورساتكانى سبلى قاضى ايشان طرفيدين ملا باباجان ملا باجبان اوغلى بله بزنى طرفيزدين آتاجان مخذوم ديكان امين بولوب باريب كوريب كليب معلوم قيلديلار مذكور ناهارنى آتقانى راست ايركان كوركاكيدين كيريب آرقاسيدين 10

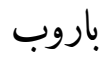
و بنجى ذالحجه47 ده نشانه آليب يكلدى مضمونى نى كورسآ من هركمنى مال لارى اوغور

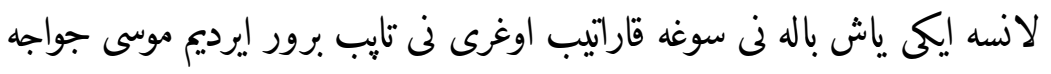

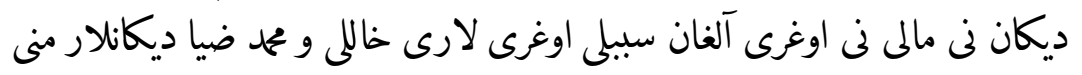
عبدالله

45 Textual variation of

46 Textual variation of معروض.

47 ذوالحجه Textual variation of. 
ديكان نى اويغه هاقورتوروب اولتورماكحى بولوب منكا إيكى مرتبه آتى آتار آنديلار اوقى تيكلادى من قاهدوم ديب ايمدى شونى سوراشيب كوروب شريعت غه موافق

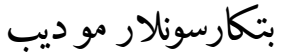

[verso]

و ينه مذكور ملا قبان باى دين جوكمه كيم نيكى ديب سورالغانده جواب بردى جوكرمه منكى إيرماس ديب خالى و مححم ضيا ديكانلارنى آلدوريب سورانميزدا48 بزلار بر يل دين بويانه عبدآله نينك اويغه بارغانميز يوق ملا قربان باى نى هم آتغانميز يوق و موسى خواجه نى مال لاريني هم اوغرى لاب آلغانميز يوق ديب إيردى سونكره خذمت لاريدين خداى نظر يوزباشى برلان يباركان 20 نشانه لارى نى برابرينده هم هاقورتوروب سوراغاميزده عبدالله خواجه نينك

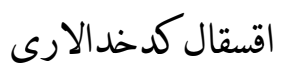

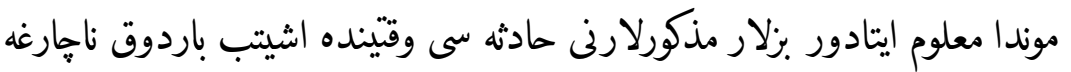

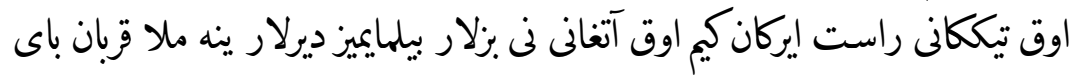
ديكان نينك اقسقال كدخدالارى آيتادور بزلار مذكور ملا قوبان باى نى بهوده يوركانى نى كوركانميز يوق ديب شايدليق 49 برورلار بزلارنينك ايشيتكان صورت واقعه لاريميز اوشبو

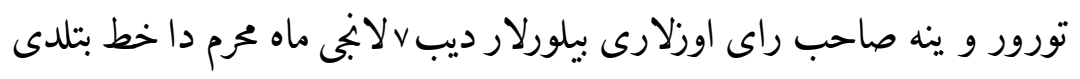

وبثا يلدا

مهر:

48 Textual variation of سوراغانميزدا

49 شاهد ليك 


\section{Document 26}

عزتلو حرمتلوشيخ نظر يساول باشى آقاميز خذمت لاريغه معروض اولكيم هزاراسب لى قلندر دركاه عالى لاريغه عريضه ايتب تخمينًا اوج طناب يريم نى اوزوم نى يوق وقتم دا جمعه نياز و بكجان و نار محمد ديكانلار طناب دفترى غه يازدوروب دور ديب مذكورغه نشانه مهربان بولوب ايركانلار بويروقلارى كيلكاج طناب دفترى نى كورولدى ير جمعه نيازلار اسمى غه إيركان قلندر مذكور من يوق ايرديم 5

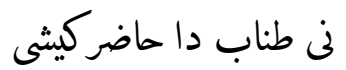
لاردين سوراب خط ايتب يبارسون لار ديب قاضى ايشان لار بار آدم لاردين سوراب خط ايتب لاردي يباريب دورلار قلندر مذكور بار ايركان خطلى ملكى نكينى توتادورمو سن ديكاندا توتماس ميز ديب تاشلاغان سببلى مجعه نيازلار توتدى ديب شهادت بركان لارنى واقعه لارى ني يازيب ياريب دورلار

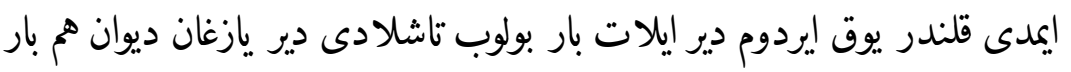
ايردى ديب شهادت 10 غه بولوب كيتكان ايمدى قلندرنى خطى بيله يرنى آنكا يانكنى دين برماكى فومايش قيلسه لار جمعه نيازلاردين خط آليب برماك كراك بولادور آكر تاشلاب فلاندغه اورناغاندين سونكرا يانكنى دين بريلماسون. ديب 
مهربان بولسه لار اولصورتدا قلندر دعوى نى قويمقى كراك هزاراسب تابعى دا فتنابته

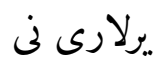

اوّل طناب بولوجاق دا تاشلاب سونكره يشيمان بولوب دعوى ايتب يوركان خلق

كوب تورور

[verso]

تخمينًا اوج تورت مينك نمرغه بارسه كراك هزاراسب قاضى ايشان لارى نى يازغان 15

خطى نى

دعوى كرنى ايكى طرفى نى قوشوب خذمت لاريغه يباريلدى نه مهربان بولسه لار آنينك بيله بويورميز

ديب صورت واقعه خذمت لاريغه عريضه قيلندى الئي

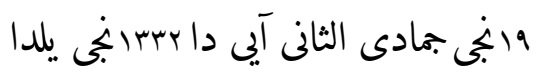

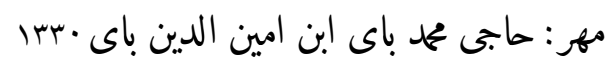


عزت و سعادت نشان يساول باشى آقانينك معلوم لارى بولغايكم جودركلدى محم اوزيم اويوم دا يوق ايرديم آقشام

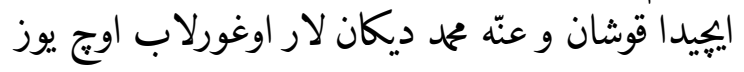

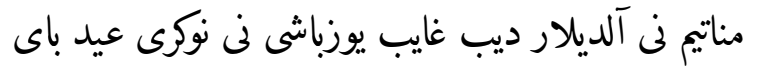
5

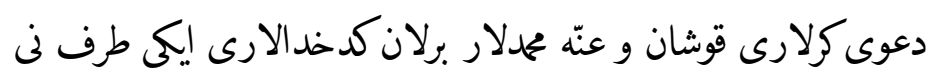

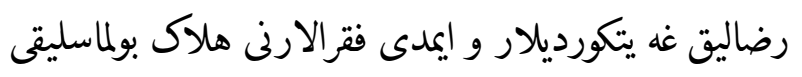

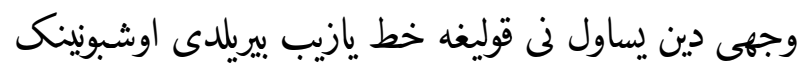
خذمت لاريغه معلوم قيلاميز ديب بو خط ويط لئل 10 مهر : جمعه نياز مرم ابن محمود ديوان ليطان 


\section{Document 28}

وزارت يناه حكومت دستكاه يساول باشى اقالاريمزنى

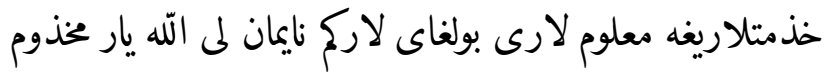

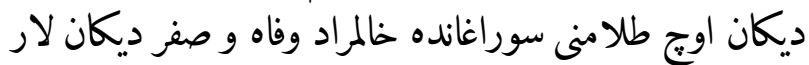
يكرمه ايكى طلامنى الديلار ديب عريضه انكان توغروسنده 5 خذمت كار قلندرنى يساول ايتب مهربان بولغان ايركانلار

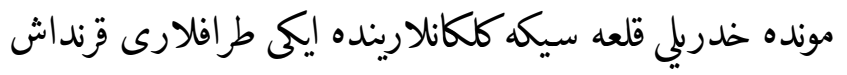

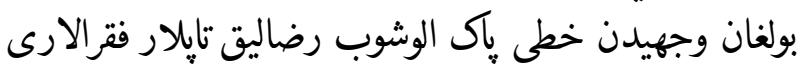

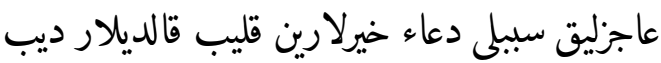

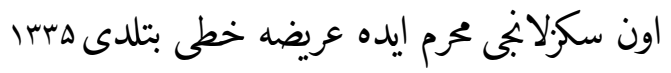

$[\%]:$ مر

$[※]$ 


\section{Document 29}

$$
\begin{aligned}
& \text { وزارت يناه حكومت دستكآ آمان كيلدى } \\
& \text { يساولباشى آقاميز خذمتلاريغه معروض اولغومات دست } \\
& \text { يلاريكم هلالى لى مسجد دورمن دين يموتلار }
\end{aligned}
$$

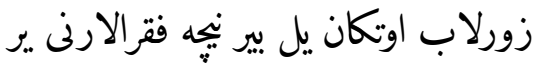

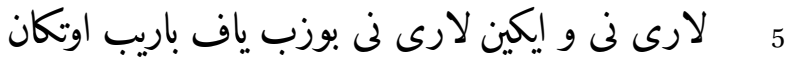

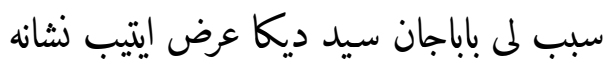

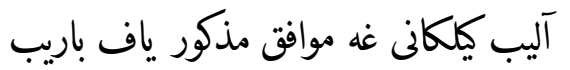

$$
\begin{aligned}
& \text { اوتكان يموتلار بيله مذكور عض كوض موى لار بيله }
\end{aligned}
$$

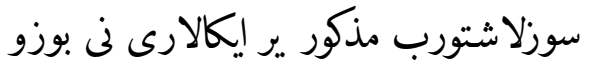

$$
\begin{aligned}
& 10
\end{aligned}
$$

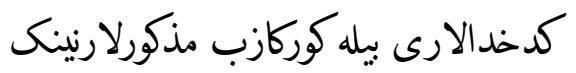

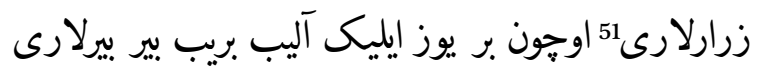

$$
\begin{aligned}
& \text { بله رضاليق غه يتديلار و داغى مذكور ياف راف ران }
\end{aligned}
$$

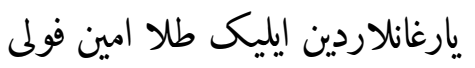

[verso]

15 و يساول حقّى آلندى شوندين خذمتلاريغه يكرمه بش طلا

$$
\begin{aligned}
& \text { بريب يباردم ديب ونجى } \\
& \text { ماه شعباندا اوشبو مكتوب مرقوم بولدى ديى ئي }
\end{aligned}
$$

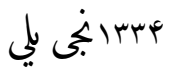

مهر: محمد يوسف باى ابن محم يعقوب ديوان

50 Textual variation of دستك

$5^{1}$ Textual variation of $ض$ درر 


\section{Document 30}

وزارت يناه حكومت دستكاه يساول باشى آقاغه كآلم حمح يعقوب ديكان حاكم مندين

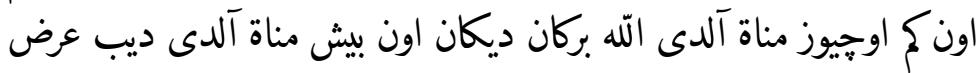

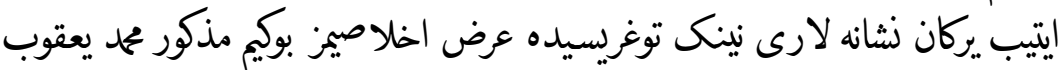

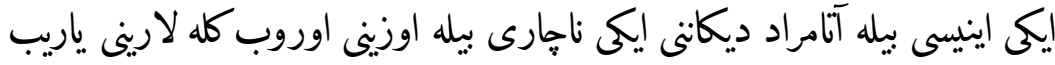

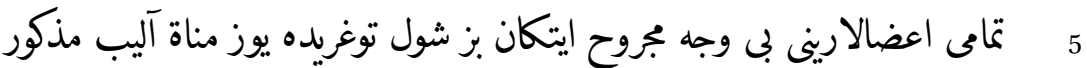

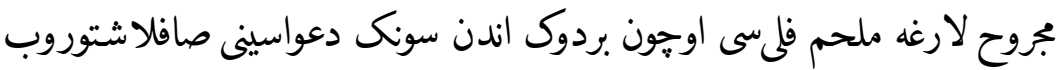

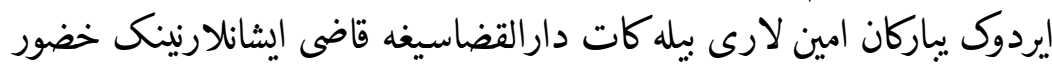

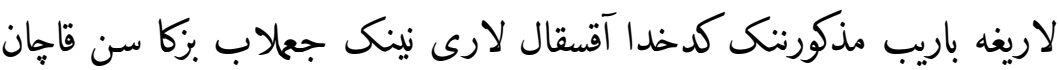

اوجيوز مناة بردينك ديب سورالدى اول جوابيده ديديك من سيزكا اوز قولوم 10

\section{بايغه}

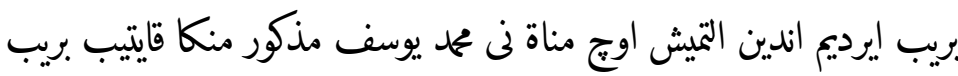

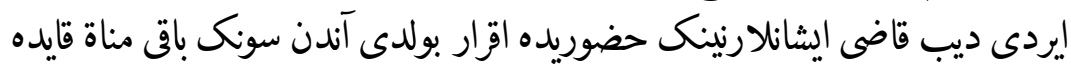
ديب محمد يوسف مذكوردين سورالغانده ديديكم يكرمه يتى مناة نى يساولى وكدخدا

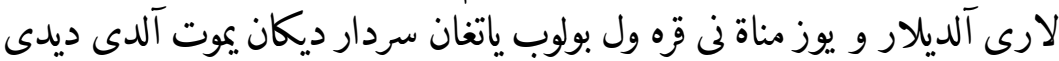

15

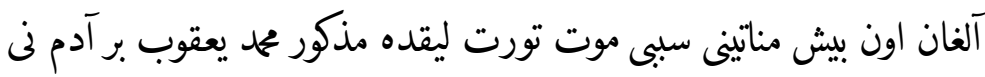

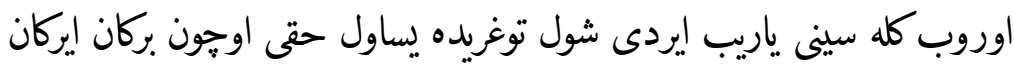

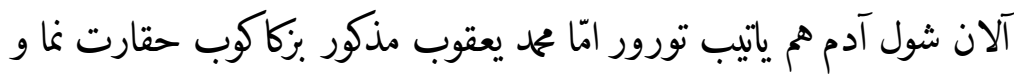

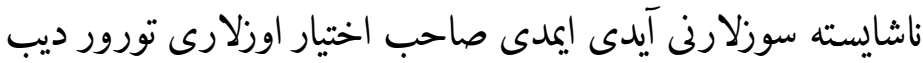
20 ايتيلدى 9 مهر: آنا بيك ابن رحيم بردى بيك هبrا 


\section{Document 31}

\section{هو}

وزرات يناه لساولاشى آقاميزنينك خذمتلا ريغه معروض اوليم هلالى فقرالاريدين عوضنياز و خدا يبركان ديكان ير جاى لارين صاتيب قرض لاريغه بيرماكَى بولوب نشانهُ عالى آليب كليب 5 ت شولارنى آلغودارلارى سوزلاشيب عوض نيازنى .يرى نى بر يوز .يكمه بيشطلاغه بر آدم آلماقِى بولوب تقسيم بولغان دا هر بيشطلا غه

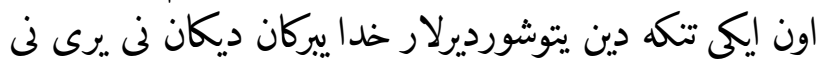

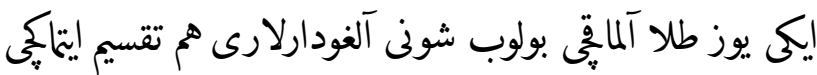

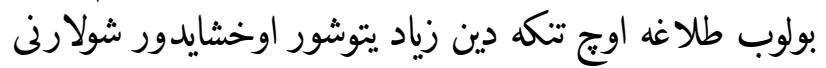
10 جواب آليب بويروق ايتسه لار ومايش لارى بله بويورميز و ينه

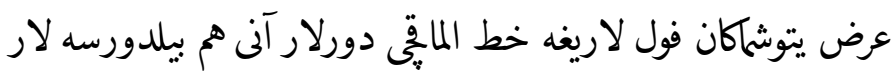

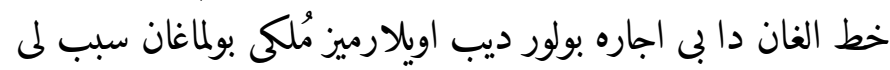

[verso]

يا الغودارلارى هر نه بارى بولسه يتوشكانيغه لايق آليب قالغان حق لارى اوخون خط آلماسون ديرلارمو شولارنى بيان

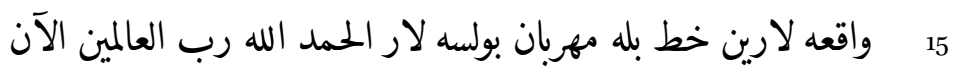

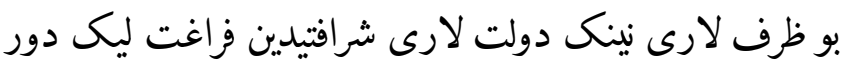
دعاء خيرلاريغه مشغولدور ديب ربع الثانى دا ـالبنى إيدا عريضه الاخلاص رق تافدى بrriابتى ليلي

$[\%]:$ مهر

آلغودارلار رضا بولسه شريعت فرمانى بله

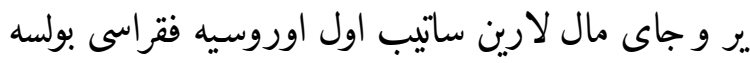

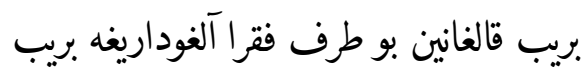

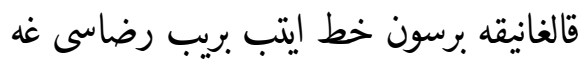
5

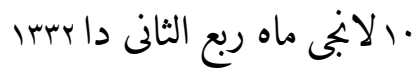




\section{Document 32}

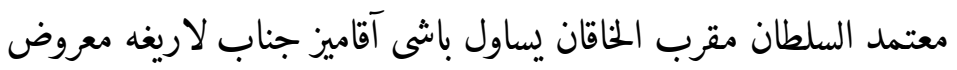

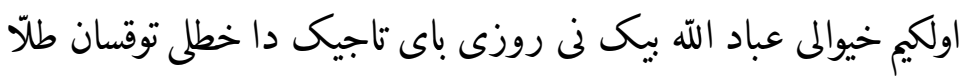

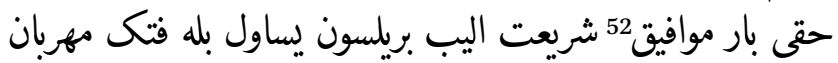

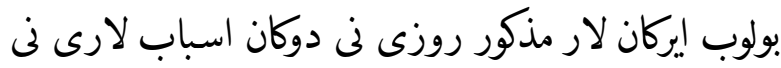
5

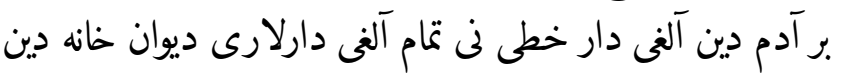

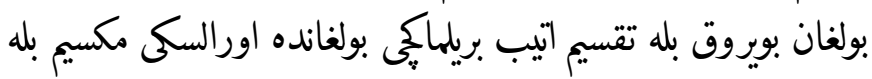

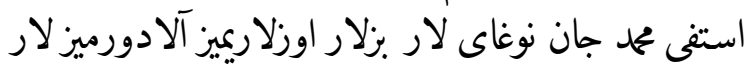

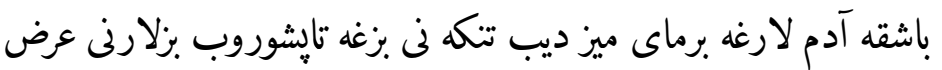
10 آينده يازيب معلوم اتيلب إيردى هيج بر جواب بوان بولماين

[verso]

توروب إيردى ينه اوروس لارنى تازه دين جواب لارى نى

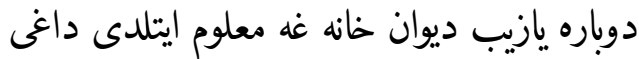

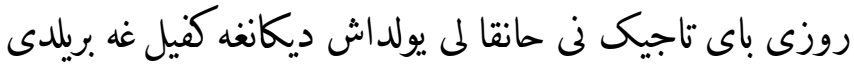
15

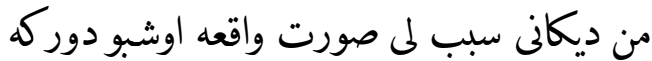

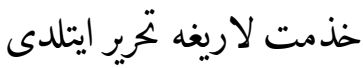

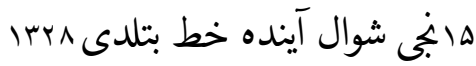

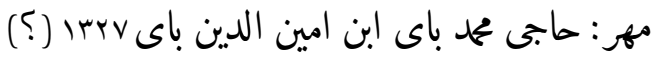




\section{Document 33}

هو

وزارت يناه حكومت دستكاه يساول باشى آقانينك خذمتلاريغه بو نوع معلوم قيلورمز تونيم قيلج بابلي اوراض باى ديكان خذمتلاريغه عرض قيلغان إيركان بير هيه نفر آدم

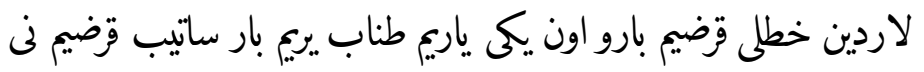

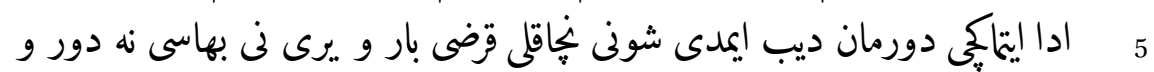

باشقه

نمرسه سى بارمو اورسيه فقراسى دين قوضى بارمو اموال و اشياءلارى و .يرى قرضيغه يتوشورمو آلغودارلارى آلماقغه رضامو شولارنى خطى بيله موندا معلوم قيلسون ديب شول سبلى مذكورنى آلغودارنى يغناب قوضى نى حساب ايتولدى بيش يوز داغى ايليك بيش طلا وضى بار إيركان و اون إكى ياريم طناب

ง..

10 نينك بهاسى ادرا بولغانى اوحون يوز طلاغه آلمايدورلار و .بر ههنه اربه53 و .يكى اوجإ و .ب ايشاك بار إيركان اوروسيه فقرينيدين قوضى يوق ايركان مذكورنينك يرى و زوسه لارى قوضيغه يتوشاكانى وخهى دين بر .يرداغى الغودارالارى اتفاق بيله مذكور

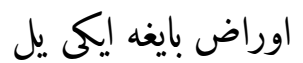
مدّتتينهِ لى بـ فيد|54 توردى لار مذكورنينك صورت واقعه سى بو طريقه إيردى

[verso]

خذمتلاريغه معلوم قيهاق اوحتون بو عريضه يباريلدى صاحب اختيار اوزلارى 15

53 sic.

54 Textual variation of فائد 


$$
\begin{aligned}
& \text { هسب يلد| } \\
& \text { مهر: بابا جان يوزباشى ابن يهلوان }
\end{aligned}
$$

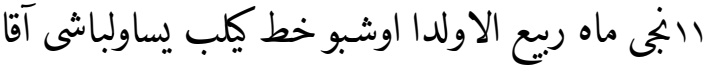

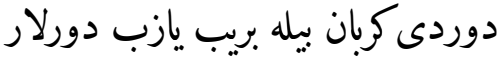

$$
\begin{aligned}
& \text { آليب قويولدى }
\end{aligned}
$$




\section{Document 34}

وزير اعظم دستور المكرم اعنى يساول باشى اقاميز نينك جناب عالى لاريغه

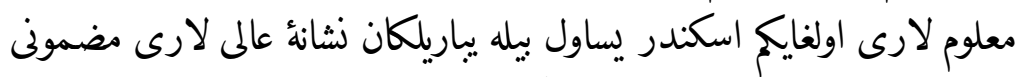

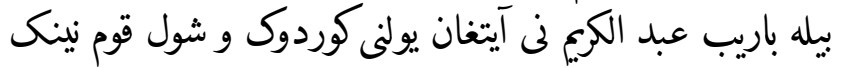

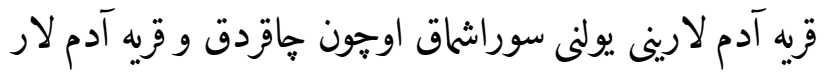

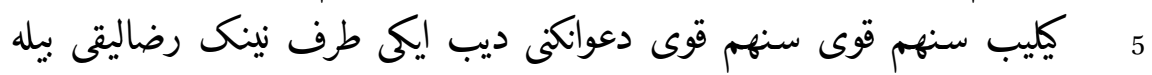
كدخدا

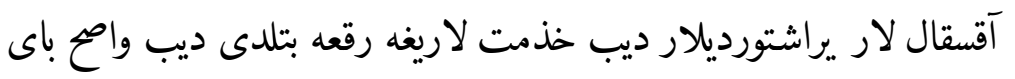

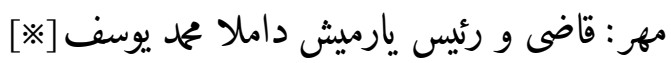

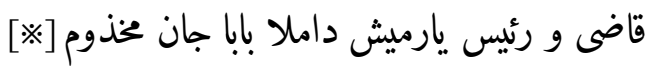




\section{Document 35}

وزارت يناه يساولباشى اقاميز نينك خذمتلاريغه معلوم

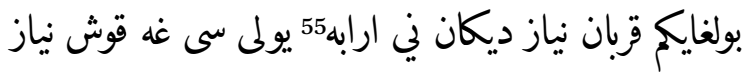
قربان نياز و روز محمد و بابا و آتا نياز و جمعه نظر و سيّد

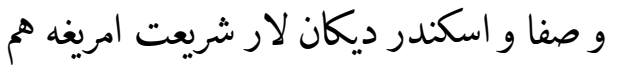
5 رضا بولماى زورليق ايتب يوركانلارى اوهون إيكى

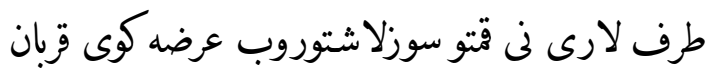

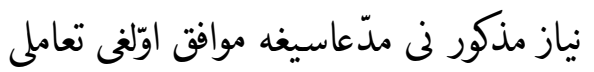

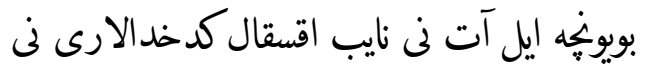

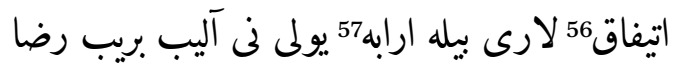
10

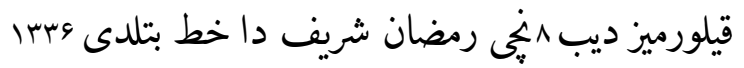

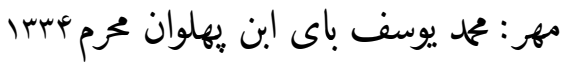

اتفاق 56 Textual variation of

57 sic. 


\section{Document 36}

وزارت بناه يساول باشى آقانى معلوم لارى بولغايكم بير مسجد قومينى ادم لاريدن عبدارمان الله بركان محمد نياز خواجه و ايش نياز و قوشه خواجه و محمج يعقوب خواجه ديكان

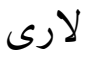
دربار عالى لاريغه عرض قيلغان إيركان يموت طايفه لارى بيش آريق طرفيكا بارغانده

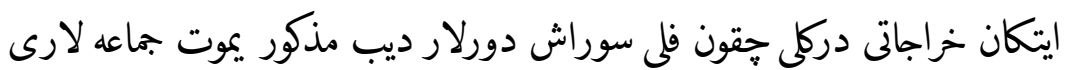

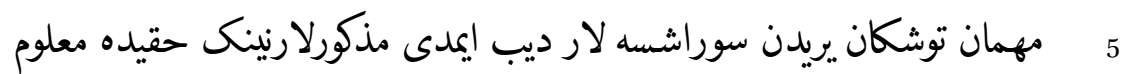

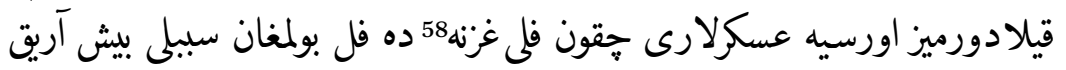

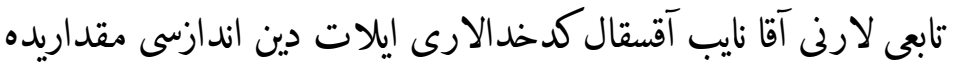

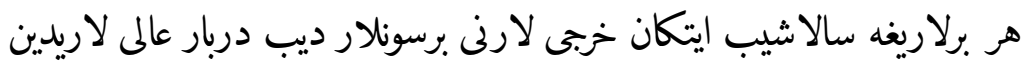

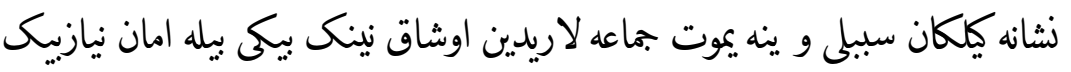
10

[verso]

بولوب توشكانده آقا نايب لارى اتفاق ايلان خراجات ايتكان سبب لم لى

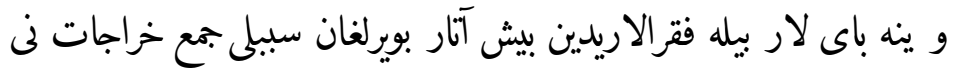

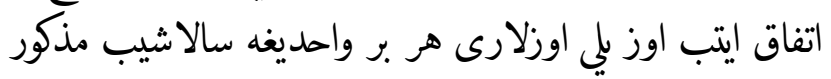

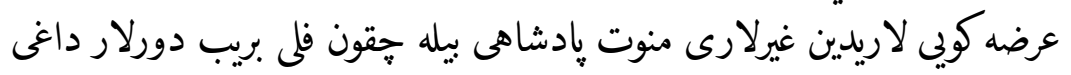
15

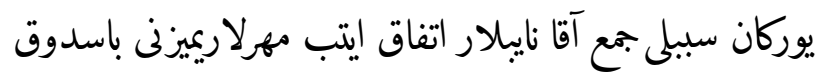

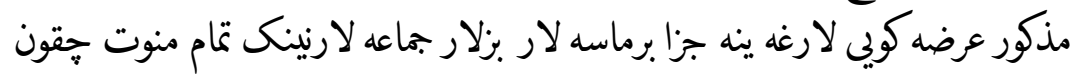
فلى لاريميز بتاى تأخير تايبب و ينه بركان فقرا هم قايتوب آلماتحى بولوب تورور ديب ماه

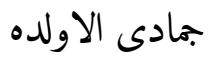

$5^{8} \quad$ Textual variation of خزينه 


$$
\begin{aligned}
& \text { اوشبو عريضه اخلاص بيتلدى وسبا } \\
& \text { مهر: محمد يوسف باى ابن يهلوان مرم }
\end{aligned}
$$

$[\%]$ اتا نياز باى ابن محمد نياز باى VIr 


\section{Document 37}

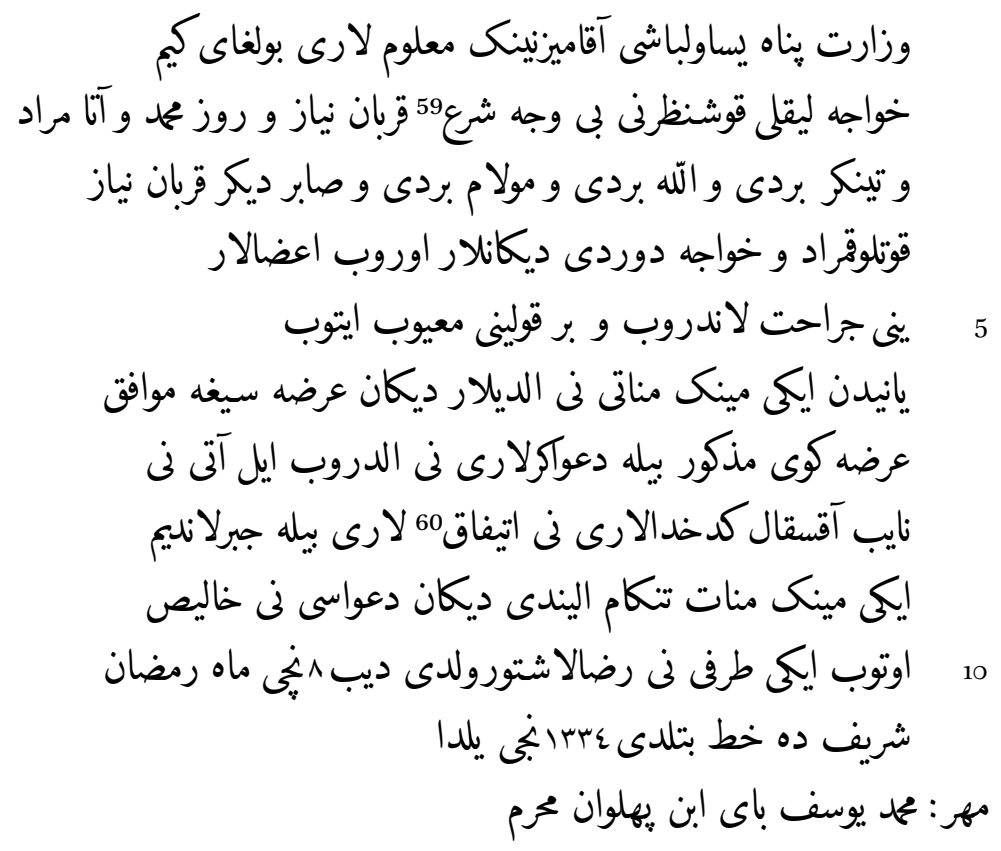

59 Textual variation of بى وجه شرعى.

60 sic. 


\section{Document 38}

وزارت يناه يساولباشى آقاميزنى خذمت لاريغه معلوم بولغايكم

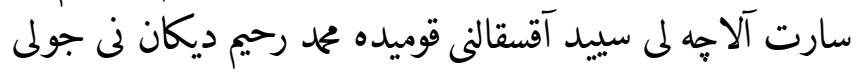
سيغه اوغرى توشوب تورت باتمن بوغداى تورت

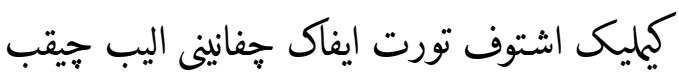
5

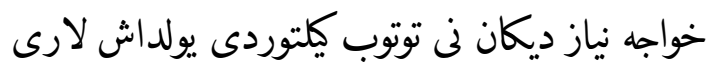

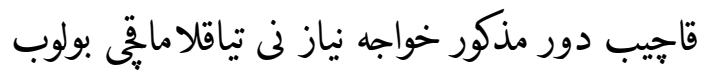
سياست ايتوب الغان وجه لارى بيله يولداش لارئ نارى سورا لغانيدا يولداشى توره و منكلى ديكانلار مذكور بولغان 10

[verso]

$$
\begin{aligned}
& \text { اقوار بولدى سونكره مذكور ايكى يولداش لارى نى آلدوردق }
\end{aligned}
$$

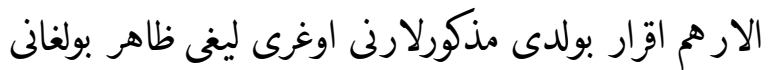

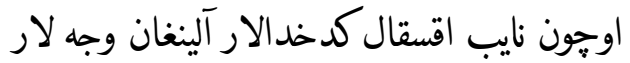

$$
\begin{aligned}
& \text { اوحون تورت يوز طلا محمج رحيم مذكورغه اليب برديلار } \\
& 15 \\
& \text { خذمتلاريغه يباريلورمو ياكه موندا اويكه ساليب آوني }
\end{aligned}
$$

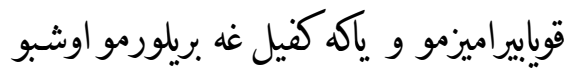

$$
\begin{aligned}
& \text { توغريدا نه مهربانيق لارى بولسه خط بيله معلوم لئي }
\end{aligned}
$$

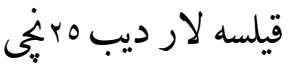




$$
\begin{aligned}
& 20
\end{aligned}
$$

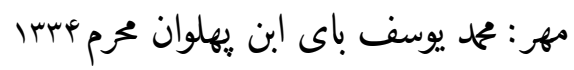

$$
\begin{aligned}
& \text { اوغرياررنى حآكم نى اوزى ساقلاب بولغاندا } \\
& \text { جقارماقغه جواب يازيلدى حاجى اوني }
\end{aligned}
$$

61 Textual variation of ذي القعده. 


\section{Document 39}

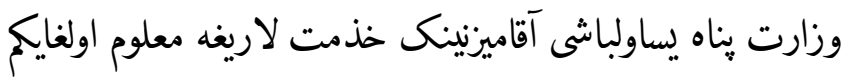

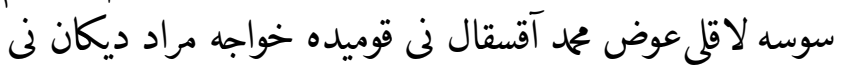

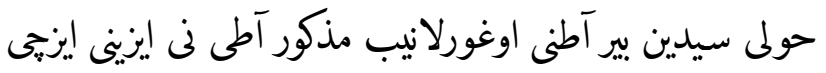

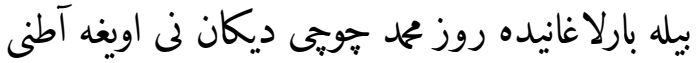

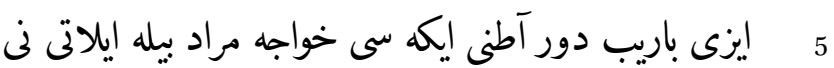

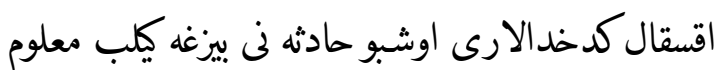

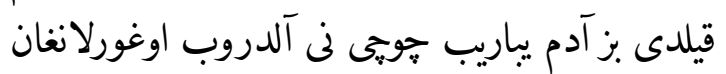

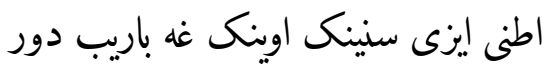

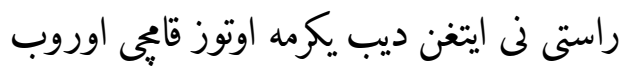
10

[verso]

عبدارحيم يوسف خواجه ابدال خواجه الاك تاى نو ديكان

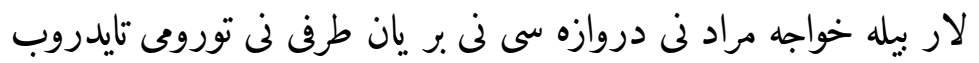

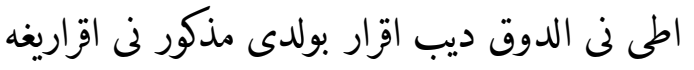
موافق مذكور يولداش لارينى آلدروب الارغه سياست 15

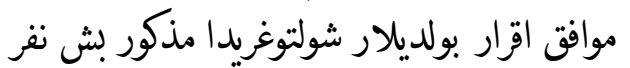
اوغرى نى اويكه ساليب اوغريلاردين سورالدى آطنى

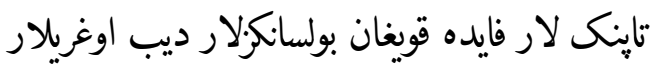
آط يوق بولدى تايلماق علاجى يوق ديديلار سونكره 20

[recto]

جويه مراد ايتدى آطم نه بير مينك ايكى يوز طلا غه سوراغانيده

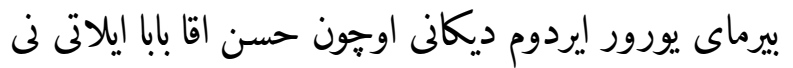


اقسقال كدخدالارى بش اوغريدين بر مينك اكى يوز طلا

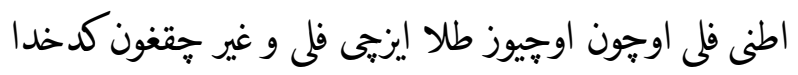

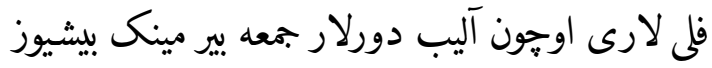

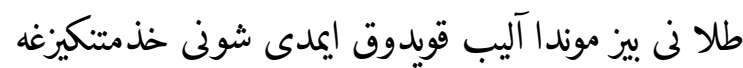

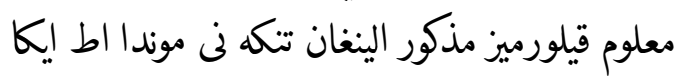
سيغه تيكيشلىسى نى بريب و قالغانى نى إيزيغه وكدخدا

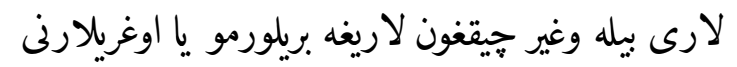
30

[verso]

الجام بولغان تنكه سى بيله خذمتلاريغه يباريلورمو اوشبو

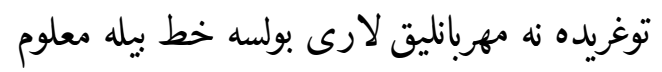
قيلسه لار ديب نونئي

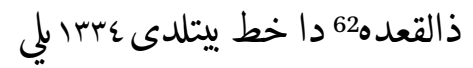

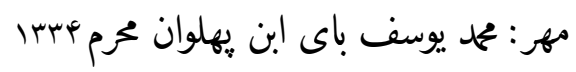

بر مينك ايكى يوز طلا نى آط ايكاسيغه بريليب اوج يوز طلا نى آلينغان لارغه بيريكان بويروق بولوب اوغريلار نى كيل غه تايشورولماقغه جواب يازيلدى 


\section{Document 40}

وزارت يناه يساولباشى آقاغه اعلام اوليم اوشبو بلي بهيى جمادى الثانيدا جواندور

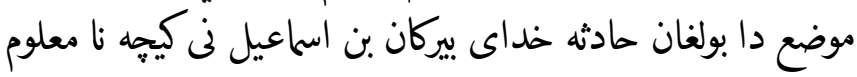

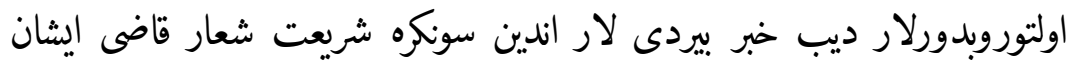

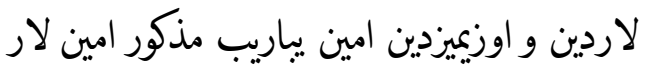
موضع مذكور نى كدخدا آقسقال لارى ايل آدم لاريب لارى ايلان بارئ باريب كوروبدورلار

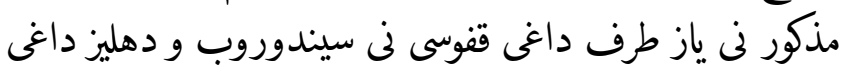

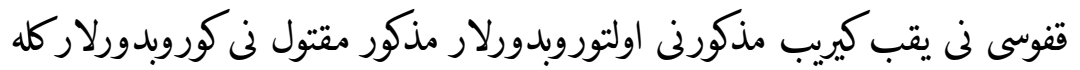

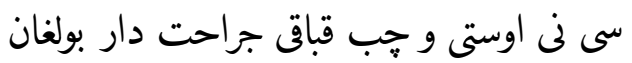
5

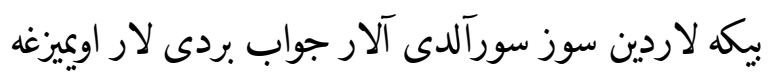

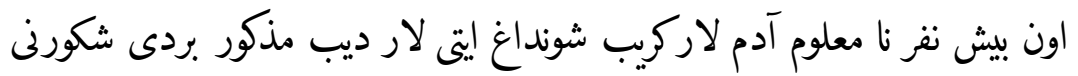

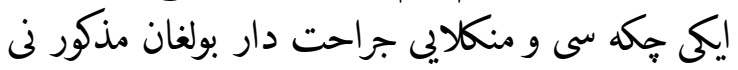

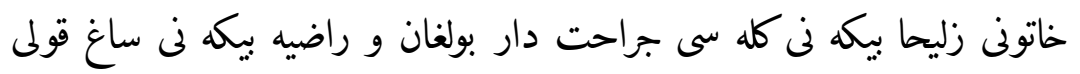

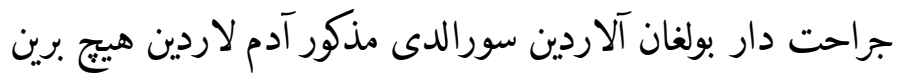

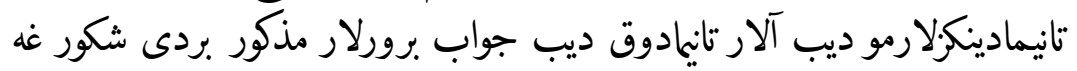

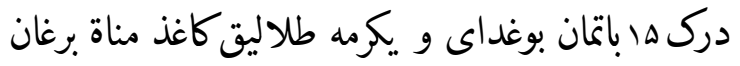

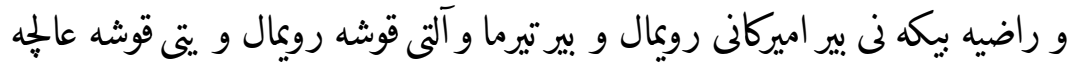

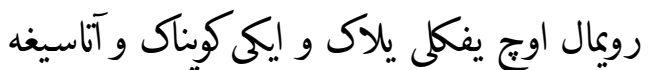
درك ب طلاليق تتكه هب طلاليق كاغذ منات ايكى كورفه لاريميز نى آليب كنيب دور لار و ينه مقتول نى اوغلى خد ايشكر ايتادور تخمينأ مب باتمان

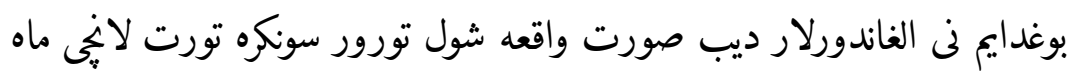

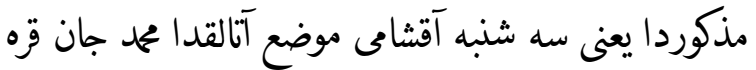

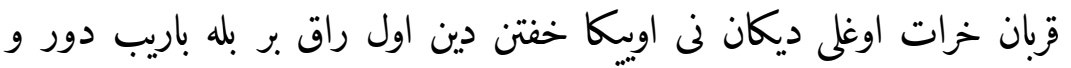

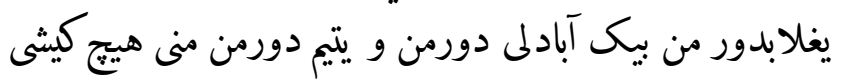


مهمان ايتادى لار ديب شولوقت دا محم يعقوب مؤذن ديكان آيتب دور بو بله

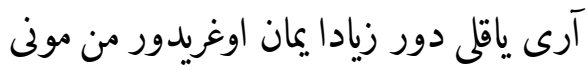

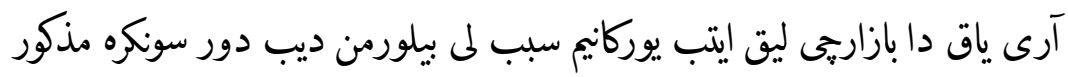

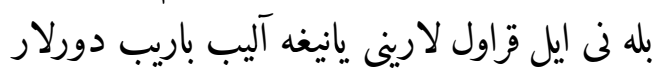
15

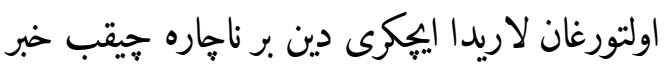

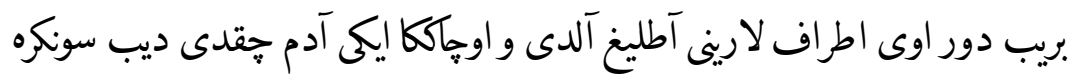

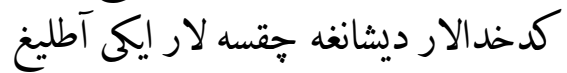

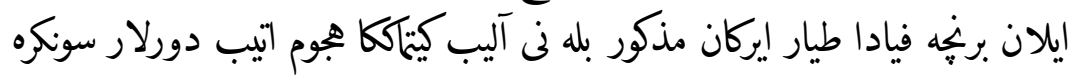

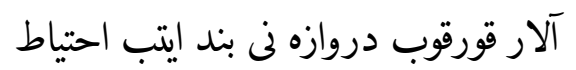
ايلان اولتوروب جيقيب دورلار داغى ايرتتكى بيزنى يانيميزغه آليب كيلدى لار مذكور بله دين سورالدى آدينك كيم دور إسئ

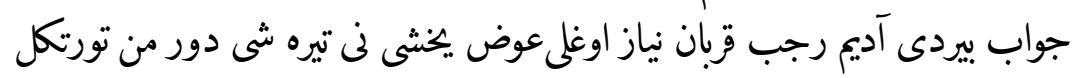

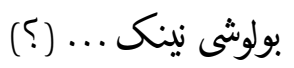
[verso]

20 مدة بر آى مقدارى بولدى بو طرفغه اوتديم بو طرف دا قوباق قزاق و باى نظرلار

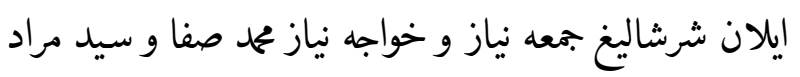
و ينه جواندورلى صفا ديكان لار يولداشلاريميز اوغرى ليق ايتارميز مذكور

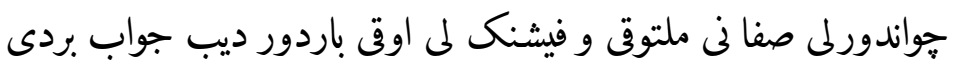
كيثى يباريب بارلاندى مذكور صفانى بر قوه ملتوقى بر تفانهه سى بrدانه بر دانكه

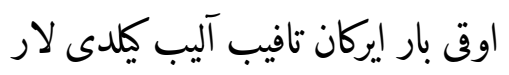

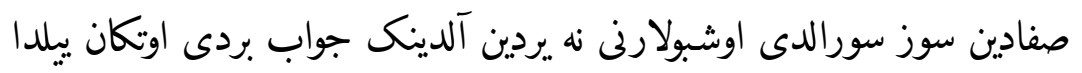

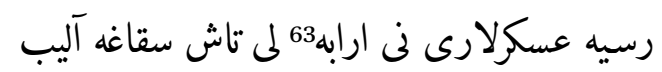

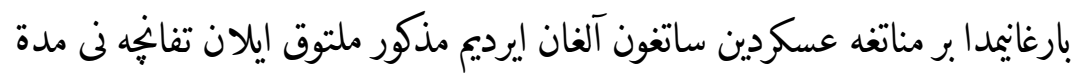
ايكى آيلقدا ايل آدم لارى ايلان كدخد الائين

63 sic. 
سوزى إيلان آرى ياق دا آق قيش منزليدا قينداشلاريم حاجى عبدالّه و حابى آليى 25 و نياز محم ديكانلاردين امانت آليب كيلديم

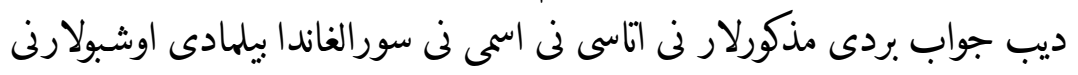

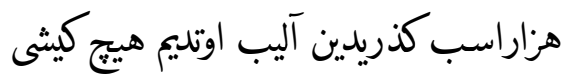

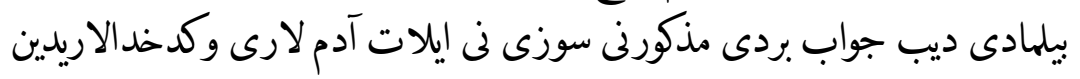
سورالدى آلار آيديلار بيزلار ملتوق سقاب مذونلا ديب

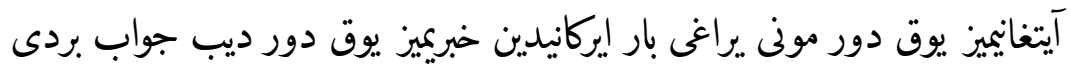

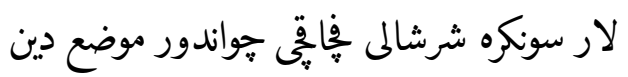

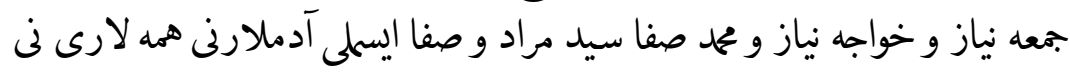

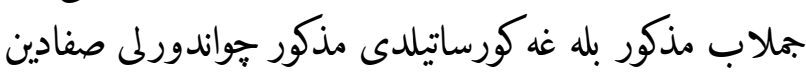

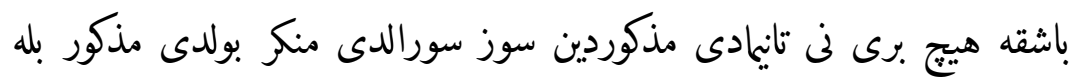
30

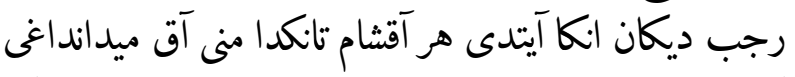

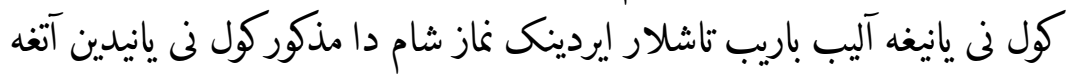

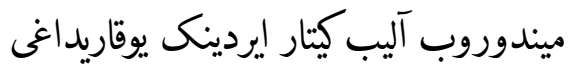

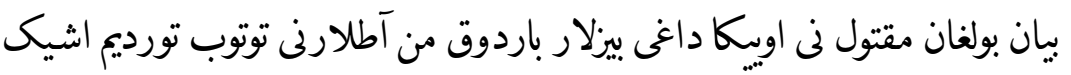

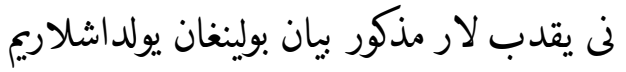
اويكاكيردى لار سونكره غوغا بولدى نه طريقه إيركانين بيلماى دور من ديدى سونكان بوره سورالدى ثخند آدم بولور سيزلار ديكاندا

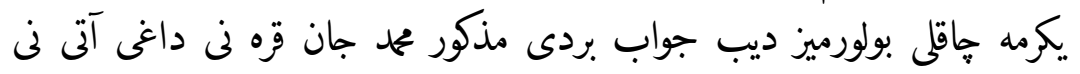

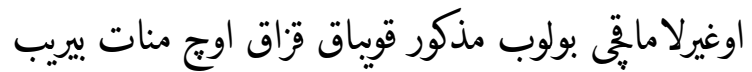

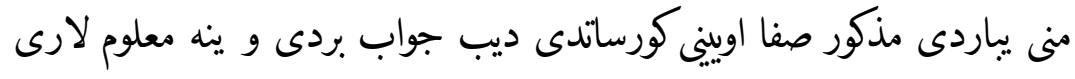

بولسون هزاراسب دين يقين وقت لاردا

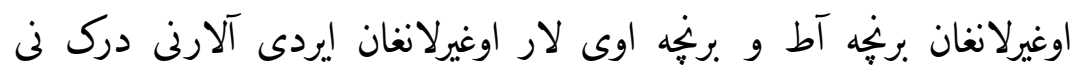

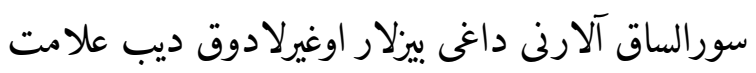

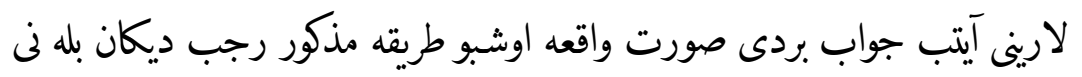

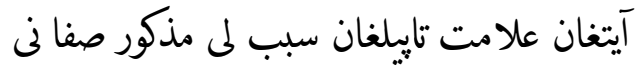


ميرشب غه تإشوروب قويولدى مذكور رجب نى تايِلغان ملتوق تفانهه نى بـدانه

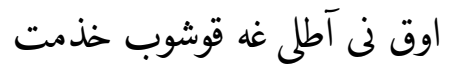

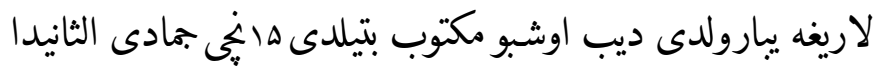
40 مهر: اساعيلخواجه ابن ابراهيم خواجه 


\section{Document 41}

معتمد الدولت مقرّب الحضرت يساول باشى آقاميز خذمت لارى غه معلوم اولغايكم

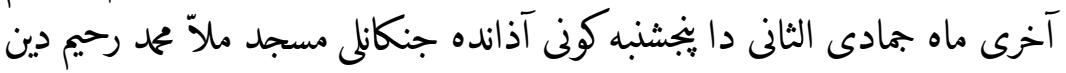

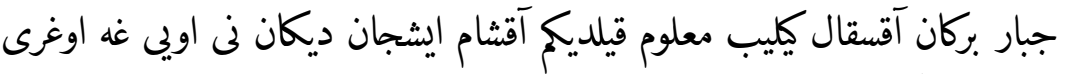

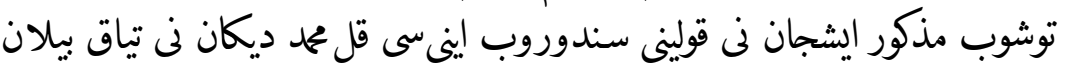

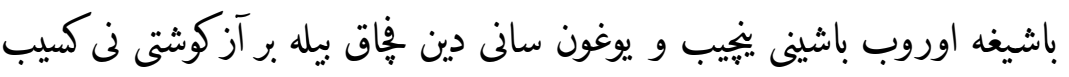

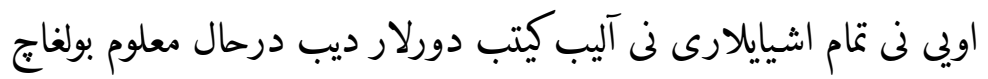

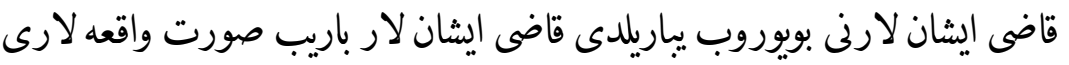

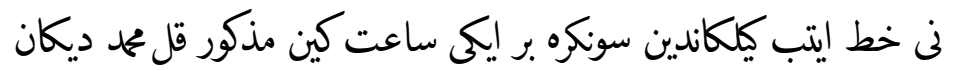

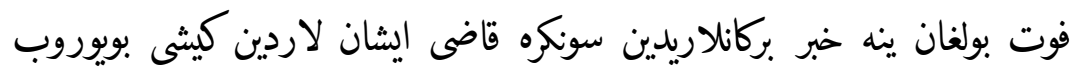

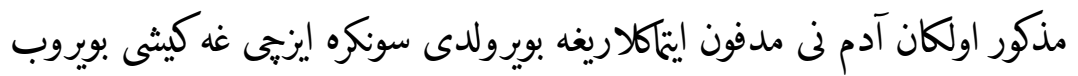

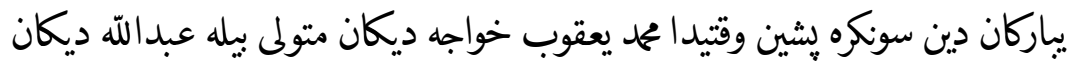

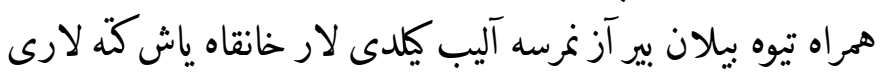

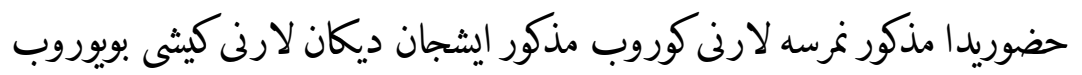

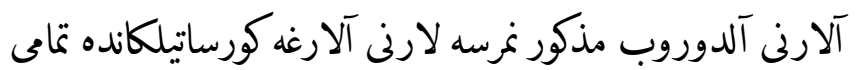

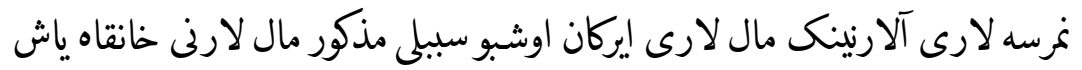

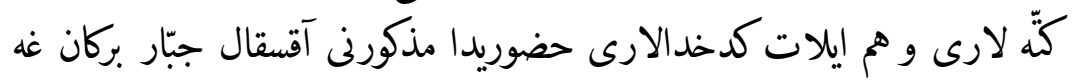

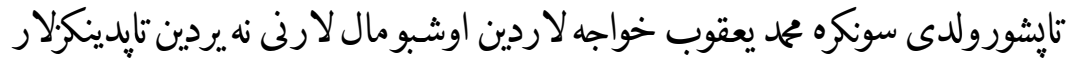

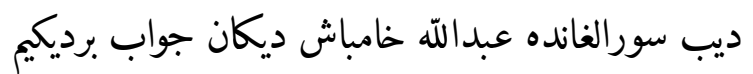
10

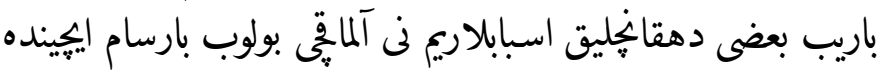

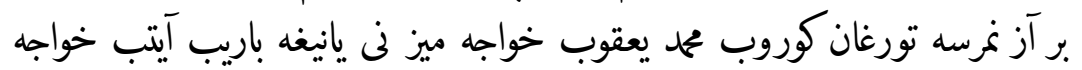

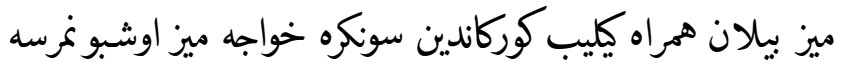


لارنى آرابه65 غه يوكلاب باى آقانى حولى سيغه آليب بارادورميز ديدى من درحال

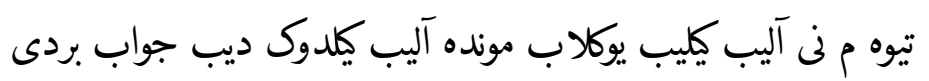

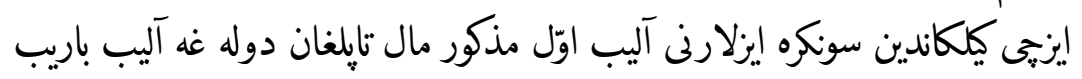

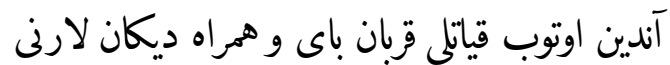

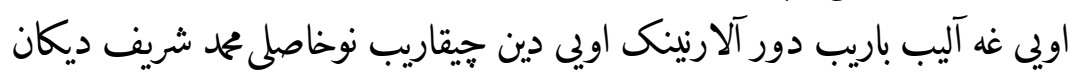

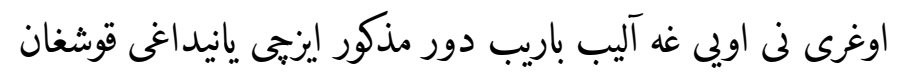

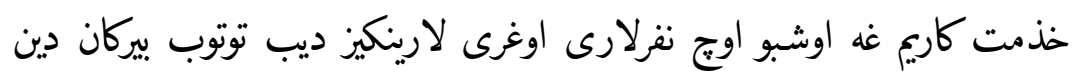

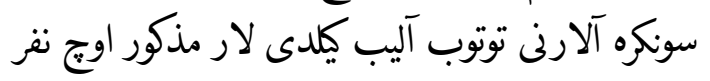

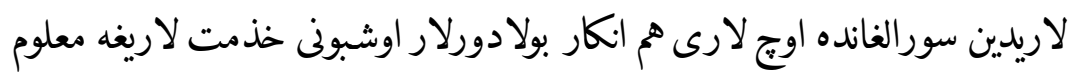
ايتادورميزيم مذكور محم شريف ديكان اوغرى اوّل

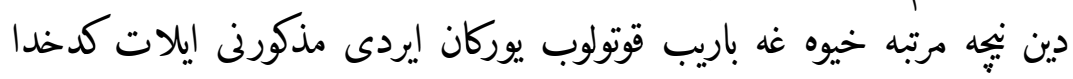

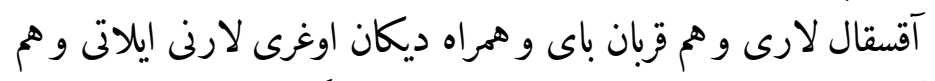

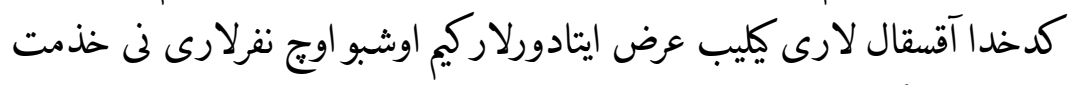
همايونلاريغه آيتيب اولتورتوروب بيرماسه نكيز بيزلار هاري

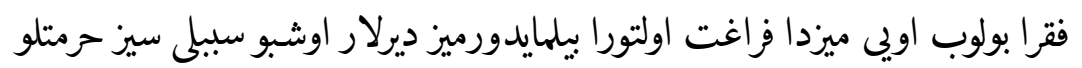

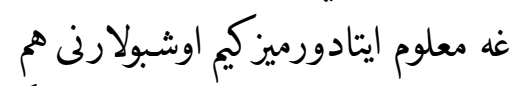

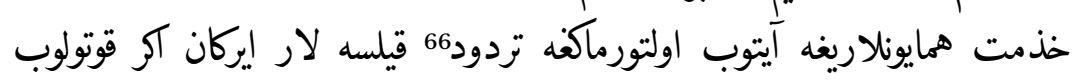

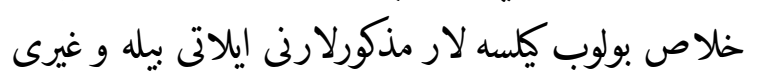
فقرالار فراغت بولمايدورغان كورونادور مذكور اوج نفرلارى نى و هم قاضى ايشان

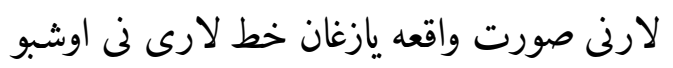

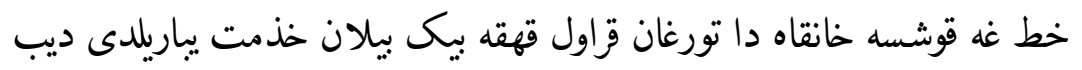

$$
\text { صورت واقعه اوشبو دور يميم }
$$

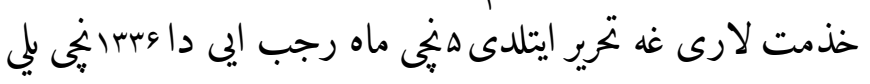

\footnotetext{
65 sic.

66 Textual variation of تردد.
} 
286

TEXTS IN CHAGHATAY

بككجانباى حابى محم يار قاضى اوغلى الله بركان كوادن اوغلى حاتى كميع قولى ترسوم باى اوغلى

25 مهر: آقُهر حاجى محمد باى الدين

Paolo Sartori and Ulfat Abdurasulov - 9789004427907

Downloaded from Brill.com $04 / 26 / 2023$ 09:59:36AM
via free access 


\section{Document 42}

عزت نشان يساول باشى اقا زيدعمره نى خذمتلاريغه معلوم

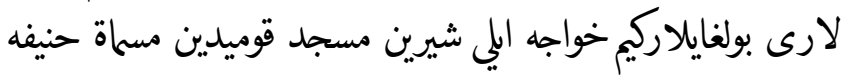

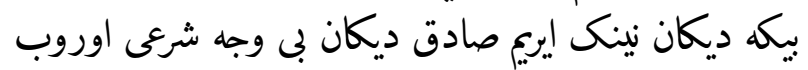
بدنيم غه جراحت سالدى ديب حاكم غه عرض ايتب يساول 5

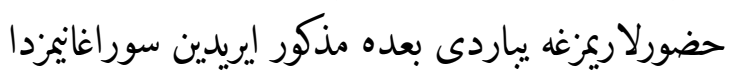

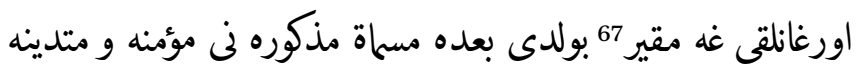

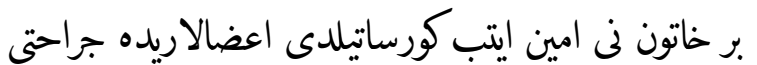

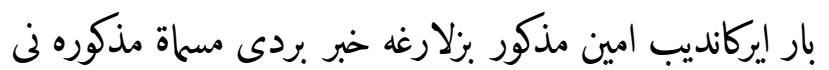
10

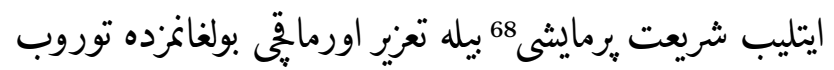

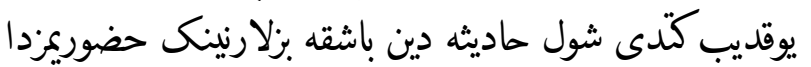

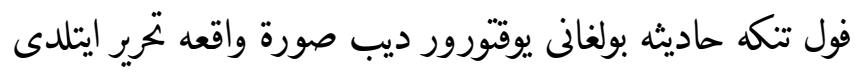

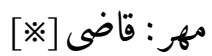

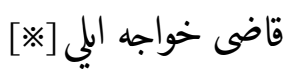

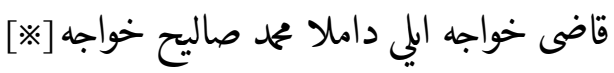

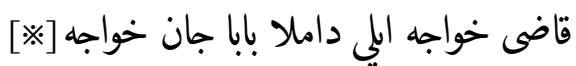

67 Textual variation of مقرك

68 Textual variation of فرمايشى. 


\section{Document 43}

وزارت يناه نجابت دستكاه يساول باشى اقاميزنينك خذمت لاريغه معلوم بولغاى

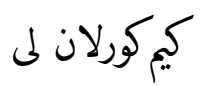

باباجان يوزباشى نينك قوى دين محمد يعقوب ايش محم اوغلى ديكان طلب كارليغ

$$
\text { قيلب اوركنج غن مكي }
$$

كليب كسل بولوب دانش ليق 69 وجهى دين اوركنج لى خواجه فارسانى قوى داغى

ويس باى ديكان نينك

اويغه بارغان ايركان شولتوغريدا مذكور ويس باى ديكان بيزغه و قاضى ايشان لارغه

$$
\text { معلوم قيلديكيم }
$$

5 كورلانلم محمح يعقوب ديكان بيزنينك جايميزداكسل بولوب ياتيب دور ديب شونى

$$
\text { برابريندا قاضى ايشان }
$$

لاريميزدين و اوزيميزدين بر آدم يباريب سوراولدى طلب قيلغان فلوينك بارمو و

$$
\text { نمرسه قرالارينك }
$$

بارمو ديب آنى برابرينده مذكور قوم نى آقسقال كدخد الارينى حضوريده محم يعقوب

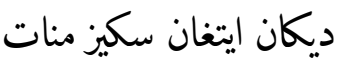

وبر اوراق بر ايشك باشقه نمرسه قرام يوقديب ايشكين مينب اويغه كيتاتقى بولوب

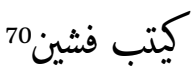

وقتيدا يولده فوت بولغان ينه بيزغه خبر كليب قاضى ايشان لاريميزدين بر آدم ني و

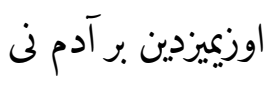

10 علم بابا

[verso]

عليه الرمه غه امانت دفن ايتدوروب قويدوق و متوفا مذكور نى ايشكى نى و اوراقى بيله

69 Oghuz rendering of تنيشليك.

70 Textual variation of بيشين. 
سكيز منات تنكه سى نى اوج كهنه جفان وبركهنه هِكان وبر جوكمه لارينى يوغويى خداى بيركان

ديكان غه تإشوردوق ديب اوشبو صورت واقعه ني خذمت لاريغه معلوم قليب

$$
\begin{aligned}
& \text { داغى }
\end{aligned}
$$

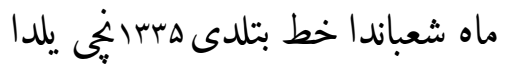

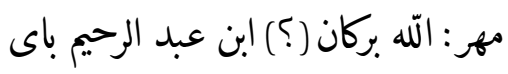

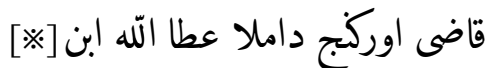

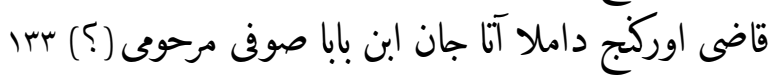




\section{Document 44}

وزارت يناه نجابت دستكاه امانكلدى باى يساولباشى اقاميزنينك معلوملارى بولغايكم ا ايجى ماه شعبان ده ايرديكم قهه ماضولى جبار بيركان آقسقال و تنكرى بيركان ى! و اوستا يعقوب لار مونده بير ناهار بيله بي يكيت نى توتوب يكتوروب معلوم ايتديلار اوشبولار ايلاتميزغه كيليب مهمان بولوب ايردى لار يوروشلارينى ناقولاى

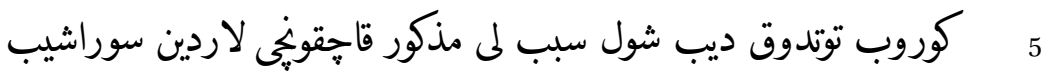

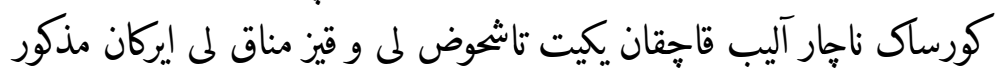
ناجار تاشحوض ده باباسى خداى بيركان جويىى ديكان نيكيفه يكاكانيده مذكور

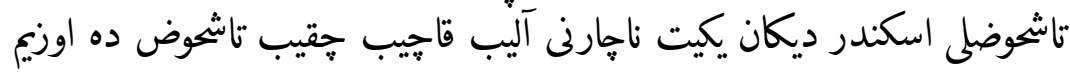

جاييم ده ايكى آى ساقلاب آندين سونك هاتكوفوكلى آته مراد ديكان نينك

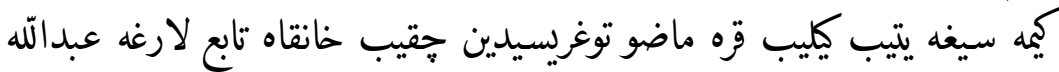
ديאن و ينه اشتمينيكيغه بارياتور إيردوك دير نمرسه قره لاريمزنى هم عبدالّه نيكى غه داله يباردوك قيزدين سورادوق سن كيشى غه نكالى 71 ياكه فاتحه لى إيردينك موديب جواب

[verso]

بيردى من هيحِيم غه فاتحه لى ياكَ نكالى 72 هم إرماسمن ديب شول سببلى مذكور

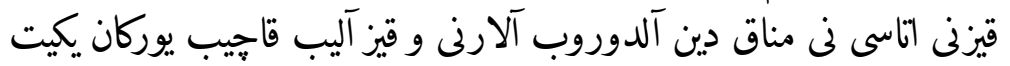

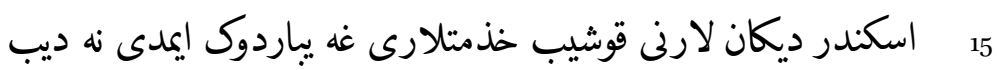

71 Textual variation of

72 sic. 
TEXTS IN CHAGHATAY

291

مهربان بولسه اوزلارى بيلورلار ديب ^ابنى ماه شعباندا بوخط بتلدى

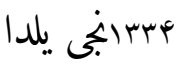

مهر: عبد الرحيم باى ابن محمد يوسف بقال

Paolo Sartori and Ulfat Abdurasulov - 9789004427907

Downloaded from Brill. come4/26/2023 09:59:36AM

via free access 


\section{Document 45}

عزت نشان يساولباشى آقاغه معلوم بولسونكيم اوشبو يردا

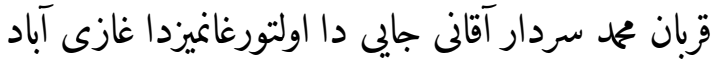
فقرالارى سردار آقاغه عرض ايتديلار اوستا محمد نياز ديكان نى

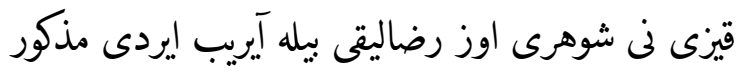

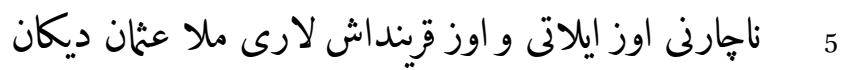

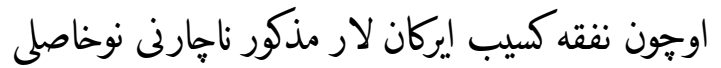

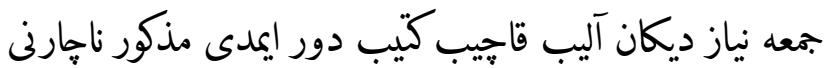

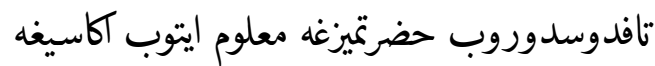

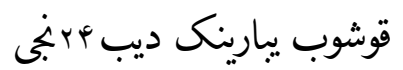
10

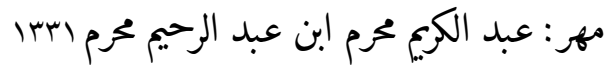




\section{Document 46}

معتمد الدولت مقرب الحضرت يساول باشى آقاميز خذمت لارى غه معروض

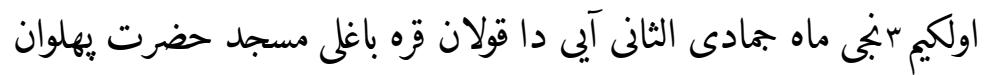

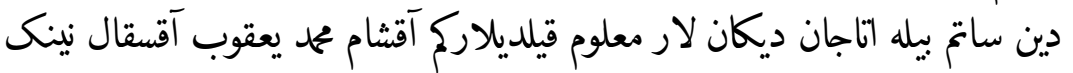

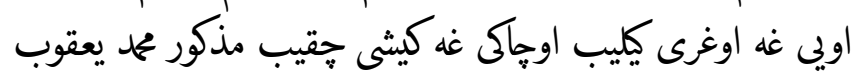

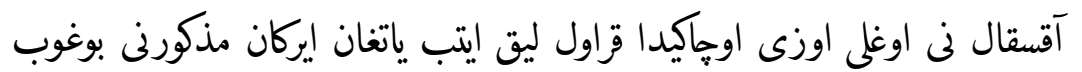

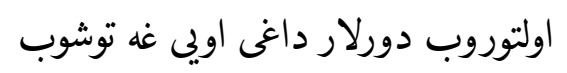

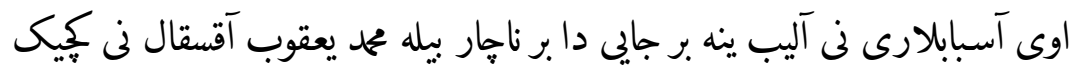
اوغلى ياتغان إيركان آلارنى اوستيغه كركانلاريدا مذكور

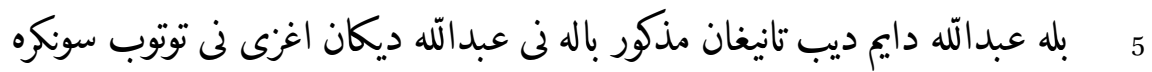

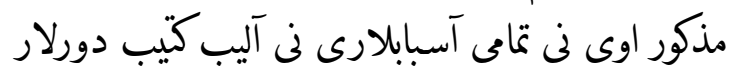

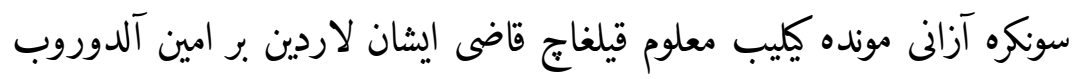

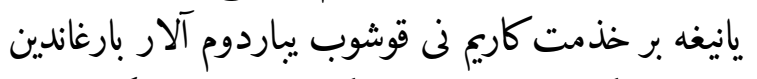

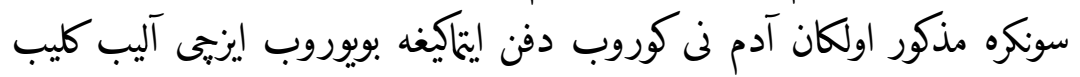

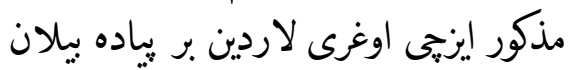

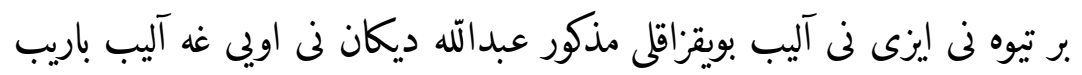

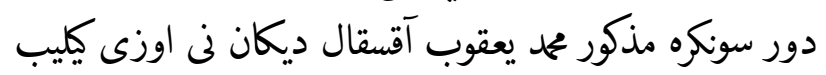

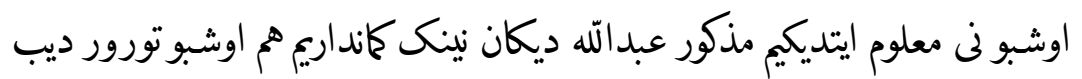

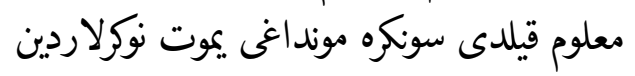
10

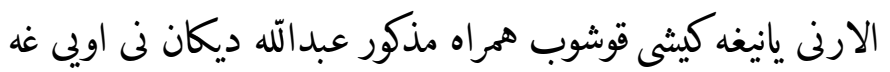

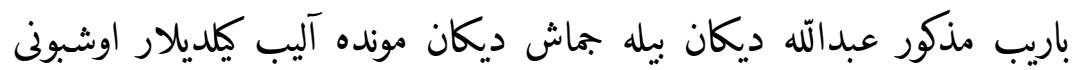

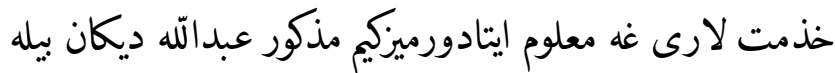

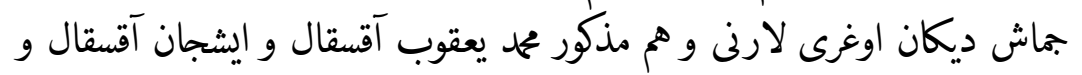

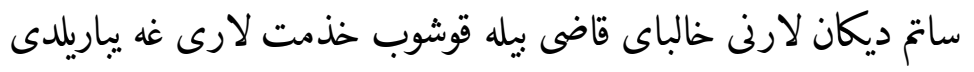


داغى معلوملارى بولغايكم دور غاويك لى محمج رحيم باى ديكان نى ياز اياميدا

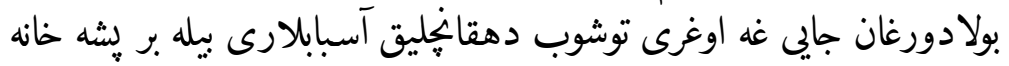

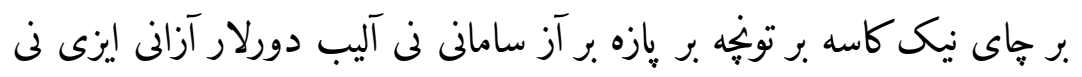

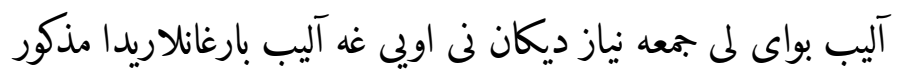
15

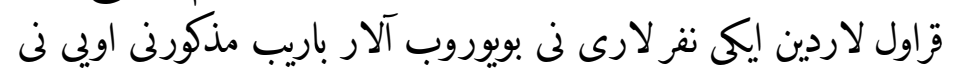

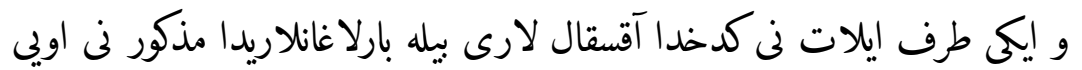

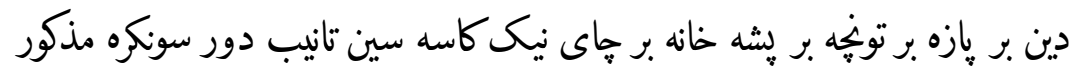

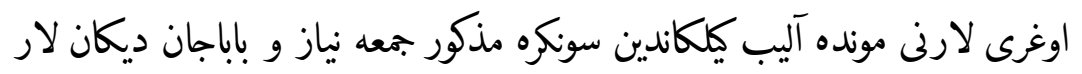

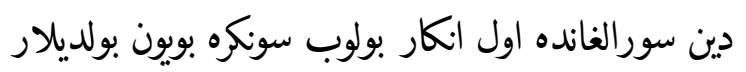

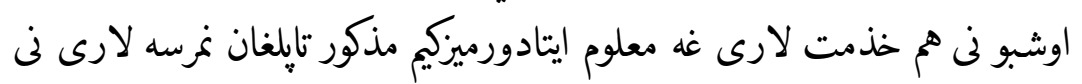

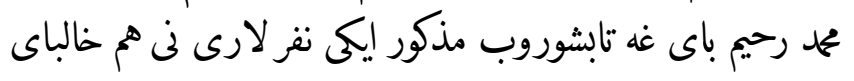

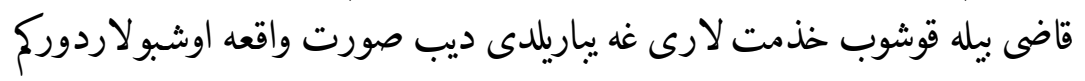
20

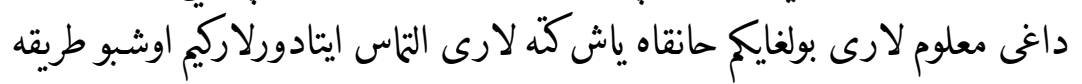

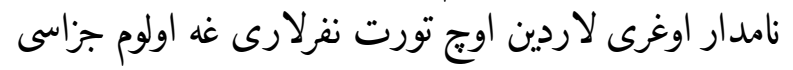

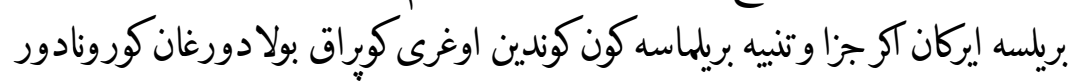
ديب ترير ايتلدى

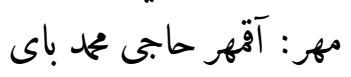




\section{Document 47}

وزارت يناه نجابت دستكاه امانكلدى باى يساولباشى

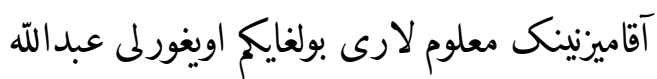

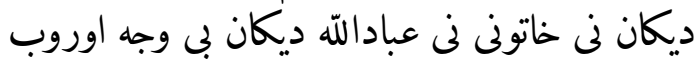

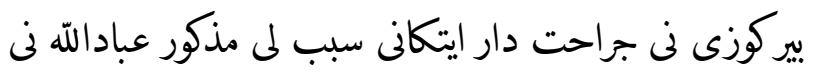
5

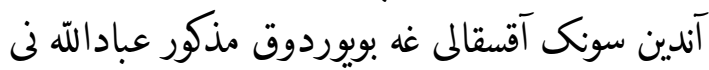
تابغين ديب شولوجه دين إيتتكى كونى قوشاق ديكان نكيدين تايبب كلتوروب همه آقسقال كدخد الارى اوزلارى تاشقاريده يراشتوروب جراحت 10

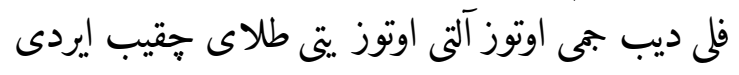

[verso]

$$
\text { شوندين سيزنينك سى } 73 \text { قلونكيز ديب بيزغه }
$$

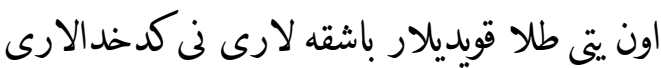

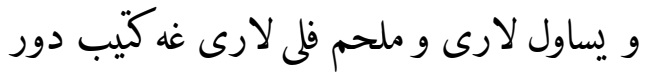
15 كليب دور ملا قربان باى و يولداش آقسقال لار دئ اوروب يتمش بيش طلام نى آلديريب آنينك

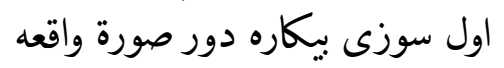
اوشبو دور ديب Vانهى ماه ريع الثانيدا صورة واقعه 20 intra يلدا مهر: عبد الرحيم باى ابن محمد يوسف بقال 


\section{Document 48}

وزارت فناه74 يساولباشى آغاميزنينك خذمت لاريغه معلوملارى بولسونك تاشيوضلى قوتلوق مراد صوفى

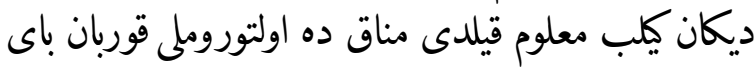

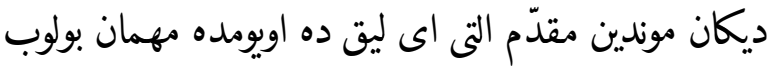
5 آليب كيتب إيردى الحال مناق بازاريده تافديم ديب مذكور قوربان باى ديكاندين سوراساق منكر بولدى مذكور قوربان باى ديكان ني يانيغه نوكر آطلى

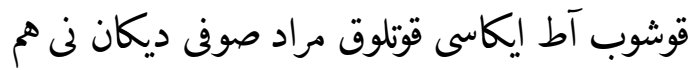
10

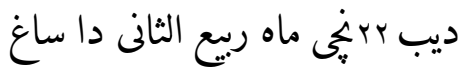

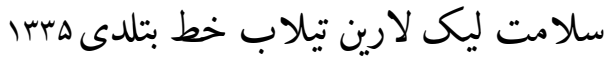

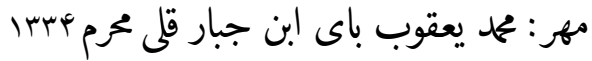




\section{Document 49}

$$
\begin{aligned}
& \text { وزارت يناه حكومت دس كامت ياسول باشى76 }
\end{aligned}
$$

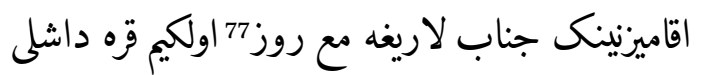

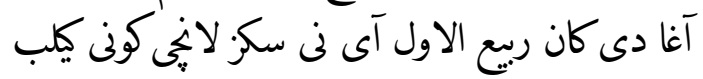

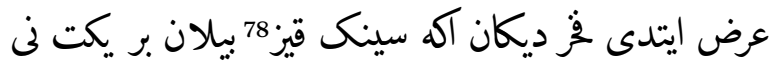

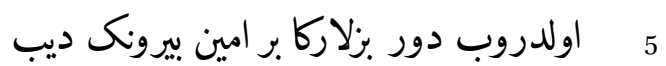

$$
\begin{aligned}
& \text { قازى79 ايشان نيك يانلا ريغه بر امين نى قوشوب }
\end{aligned}
$$

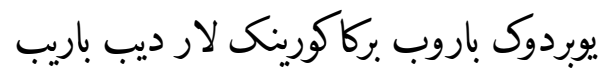

$$
\begin{aligned}
& \text { ميت لارين كورب ميتنى ميت ين إيكالاريغه } \\
& \text { بيروب يوبردوك ديرلار جاراجتى } 80 \text { بارمو ديب ديب دئ } \\
& 10
\end{aligned}
$$

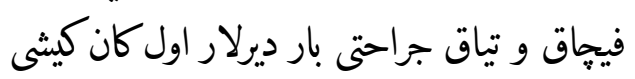

$$
\begin{aligned}
& \text { لارنى خوس تار لاريدين سورادق دوانكز8} 82 \text { بارمو ديب لايبي } \\
& \text { آلار آى ديلار إيكى سينى بركا اول دركان دين سونك لارين }
\end{aligned}
$$

[verso]

$$
\begin{aligned}
& \text { دواميز83 يوق دى ديلار ديب ريع الاول } \\
& 15
\end{aligned}
$$

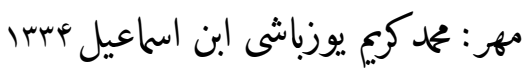

\footnotetext{
75 Textual variation of دستكاه.

76 Textual variation of

77 sic.

78 sic.

79 Textual variation of قاضى.

80 جراحت 8 . Textual variation of.

81 sic.

82 Textual variation of دعوا.

83 sic.
} 


\section{Document $5^{\circ}$}

\section{هو}

عزت نشان يساولباشى اقانينك معلوم لارى بولغايلاركيم و يارميش

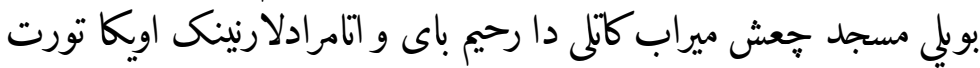

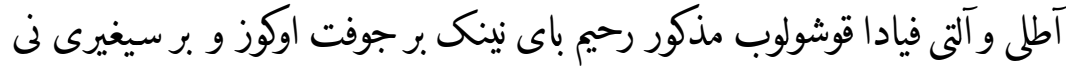

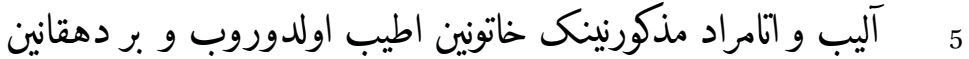

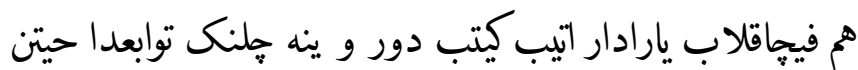

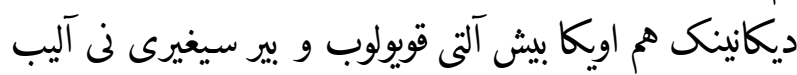

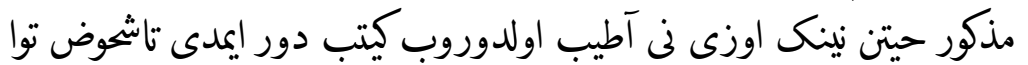

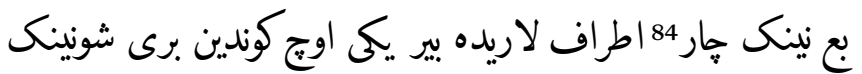
10

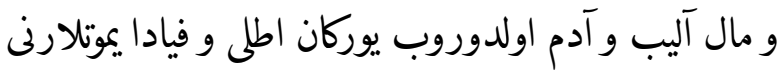

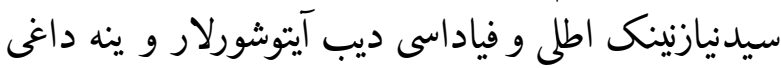
تاشحوض فقرالاريغه بي تيكيش بى اورون و بير قاره ايش لادئ لارنى

[verso]

ايتيب سن دا فلان نمرسه و فلان وجلاريم85 بار ديب بي تيكش

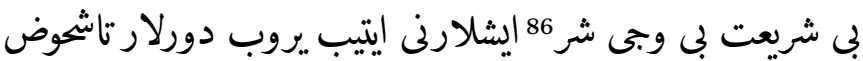
15

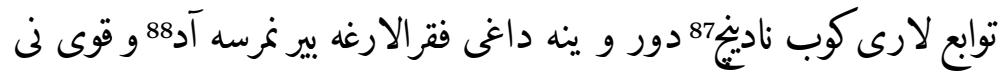

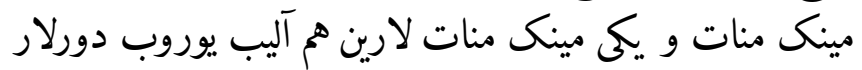

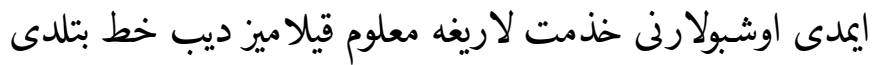

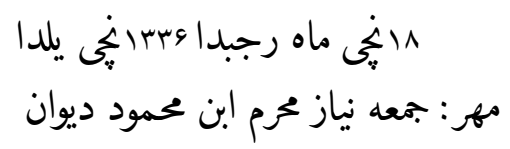

84 Textual variation of

85 Textual variation of وجهار 86.

86 Textual variation of بى وجه شورئ.

87 Oghuz rendering of ناتيني

88 Oghuz rendering of آتئت. 


\section{Document 51}

$$
\begin{aligned}
& \text { عزت و سعادات نشانه يساوباشى } 89 \text { اقانينك معلوم لارى بولغاى } \\
& \text { لاركيم ايش جان باى ديكان نى اويكا اوغرى توشكان }
\end{aligned}
$$

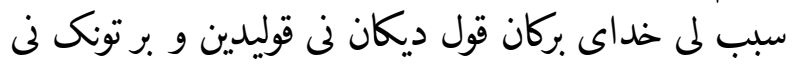

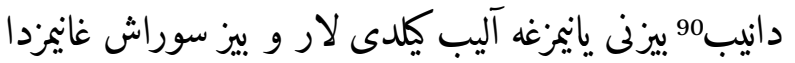

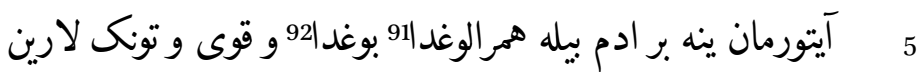

$$
\begin{aligned}
& \text { الديم ديب ايقرار } 93 \text { بولدى و شوندين سونكا اقسقال وكدخدا }
\end{aligned}
$$

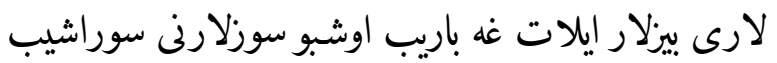

$$
\begin{aligned}
& \text { سونكرا يانيكيزا يكلتورورميز ديب كيل بولوب اليب اليب كيب إيرديلار }
\end{aligned}
$$

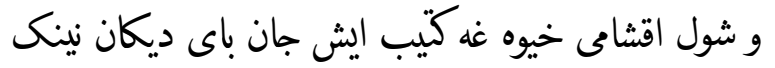

$$
\begin{aligned}
& 10
\end{aligned}
$$

$$
\text { ديكان كوب بيهوده يمان آدم دور ايمدى }
$$

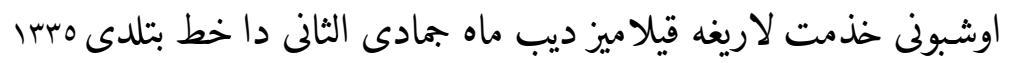

$$
\text { مهر : جمعه نياز محرم ابن محمود ديوان }
$$

89 Clearly يساولباش.

90 Oghuz rendering of تنيب.

91 Fonetic rendering of همراهليقد

92 بوغداى

93 اقوار Textual variation of 


\section{Document $5^{2}$}

وزارت هناه و حكومت دستكاه يساوبلاشى آقامينينك

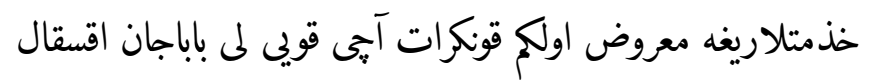

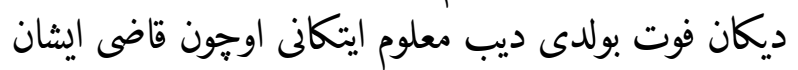

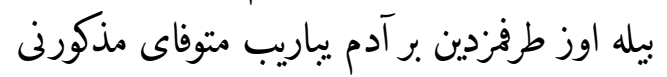
5

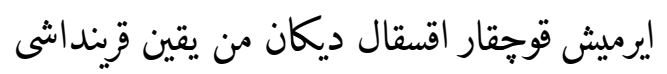

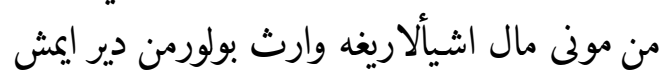

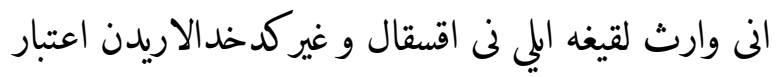

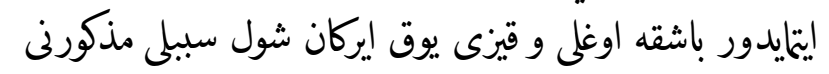
10

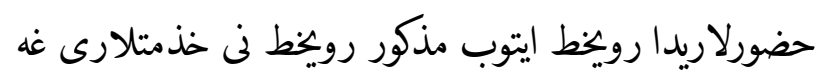

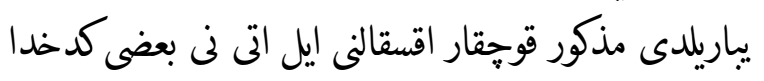

[verso]

$$
\begin{aligned}
& \text { لارى وارث ليق و قينداش إيركانيك لارى راست }
\end{aligned}
$$

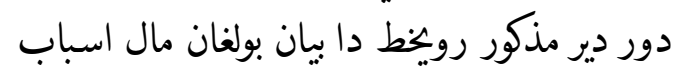
15

$$
\begin{aligned}
& \text { معلوم قيلسه لار ديب }
\end{aligned}
$$

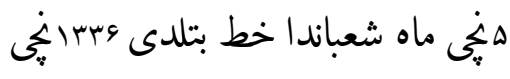

$$
\begin{aligned}
& \text { مهر: محم يوسف باى ابن بهلوان مرم }
\end{aligned}
$$




\section{Document 53}

وزارت بناه يساولباشى اقاميزنينك خذمت لاريغه معلوم بولغايكم

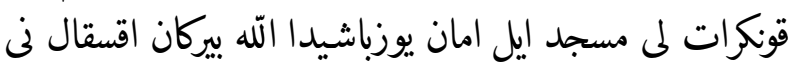

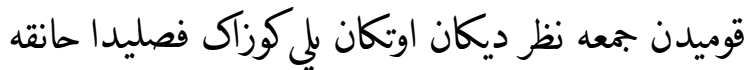
بازاريدا بر آطين اوغورلايتيب اوغرى سى نى نى هنوزيخه 5

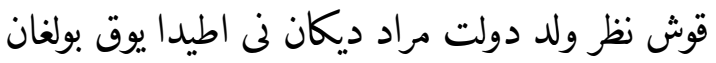

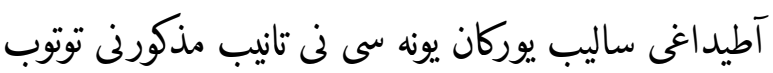
حضوريزغه كيلتوردى بز سورادوق سن بو يوني نانه نى قايدين الدينك مونى اوغورلانغان اطلى نى اوستيده كيتكان يونه 10 بازاريدن ساتغون اليب ايردوم ديب بيز ينه احتياط ني

[verso]

بله تنتيش ايتب سورادوق يوق بولوب اوغورلانغان

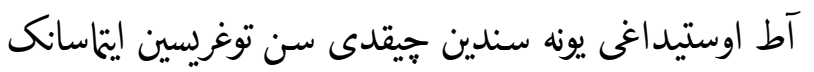
سينكا جزا بيريلور ديب شولتوغيدا قوش نظر ايتدى سئي 15

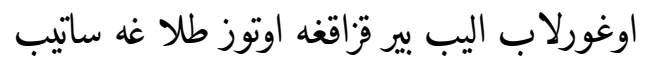

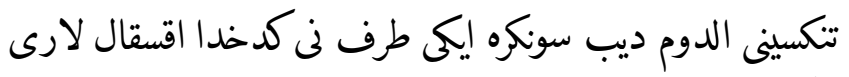

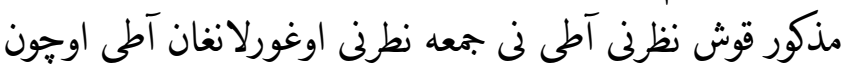

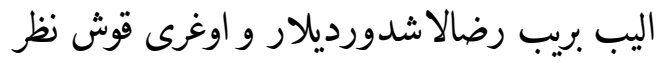
20

95 Textual variation of التماس. 
تيلايدور لار شول سبيلى مذكورنى ساقلاندى ايمدى مذكورنى الارينى ايلتاسف لارى بويونهه مهربانيخ لارى بولسه

[recto]

بوشايتب يارورميز و آكر موندا يبارسونلار ديكان

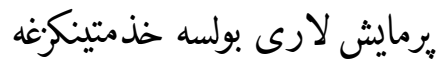

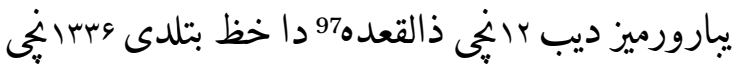

مخفى قالماسونكيم مذكور قوش نظرنى اقسقال كدخد الارى نى ايلتاس 98

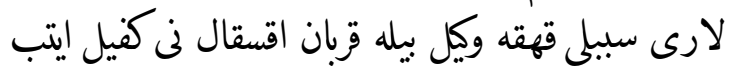
تإشوردولار مهر: محمد يوسف باى ابن يهلوان مرم 


\section{Document 54}

عزت نشان يساولباشى آقانى معلوم لارى بولسون بانيى جمادى الاول دا دوشنبه كيحى يعنى كيحه جهواندور موضع دا بولغانحادثه خدايبركان اشنياز ديكان نى ايشكى نى آلديدا بر درخت دين آسيب اولتوروبدورلار وآقعه ني خبر بردى لار شريعت شعار قاضى ايشان لاردين و

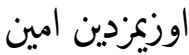
يباريب موضع مذكورنى آقسقال كدخدا مردم لارى ايلان مذكور امين لاركوركاندين سونكره دفن 5 كيجه دا مقتول ني اويوندا

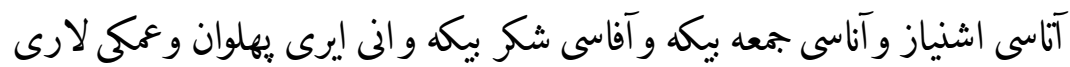

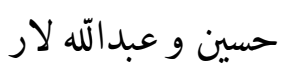
ياتغان لار مذكور مقتول خاتونى رحميه بيكه بيله بر اويدا ياتغان ليك دا اوشبو واقعه دين هيج برلارى خبر تإمغان لار تانك دا عبدآله ديكان طحارت اوحون ديشان غه جقيب انى كوروب

ني كاره ايركانين بيلماى مذكور حسين ديكان غه خبر بريب دور جقيب كوروبدورلار واقعه شولطريقه إيركان اندين سونكره مقتول نى خاتونى رحميه بيكه دين سوز سورالدى ايتوريميم كيجه وينياز و عبد الرمن و آدم باى تقلاق ديكان لار بيله ينه بر ادمكريب مذكور نام لارى بيان بولغان اوحلارى إيرينى آليب كيتدى لار برى منى باسيب اولتوروب قالدى 
[verso]

منداغى بيخور بولوبكن باشقه ايش نى بيهاى دورمن قفو اوستدين ايليك إيركان

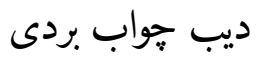

سنى باسيب اولتوروب قالغانكيمدور ديكانداكورسام تانيدورمن ديب نشانه لارين

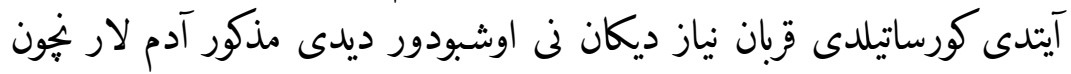

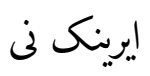

بو طريقه ايتدى لار ديكاندا إيري نى مذكور ويسنياز خاتونى بيله ايشى بار ايردى

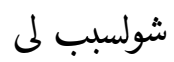

ديب جواب بردى سونكره مقتول ني حوستارلارى اشنياز جمعه بيكه شكربيك. لاردين سوز سورالدى آلار ايتوركيم بزلارنى قانداريمز ويسنياز بيلان عبدالرحن

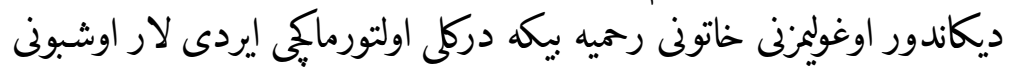

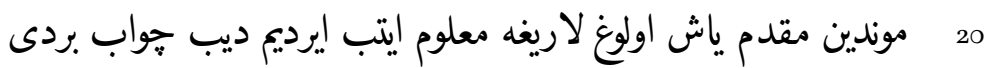
مذكورنى سوزى نى قلندر آقسقال غايب نظر ارباب لاردين سورالدى معلى معلوم ايتب إيردى ديب جواب بردى لار سونكره ولسنياز و عبد الرحن ادم بإى تقلاق قربان نيازلا ردين سوز سورالدى آلار منكير 100 اندين سونكره مذكور تورت لارى نى ميرشب غه تاشوروب مذكوره رحميه بيكه نى كفيل كا بريب صورت واقعه نى خذمت تحرير قيلنب

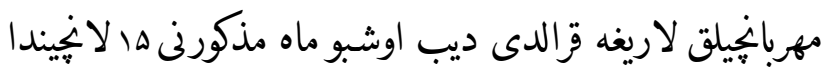

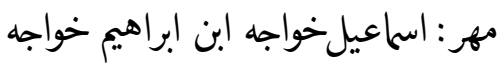

99 Textual variation of بيخبر

100 Textual variation of 


\section{Document 55}

ه

وزارت يناه نجابت دستكاه يساول باشى اقاميزنينك خذمتلاريغه معلوملارى بولغايك اوركجدا غايو موضعى دآَطليخ .يرده اولتوروملى سيّد حاجى باى اوغلى نينك دركاه عالى لا ريغه عرض ايتب اوشبو ليوضي

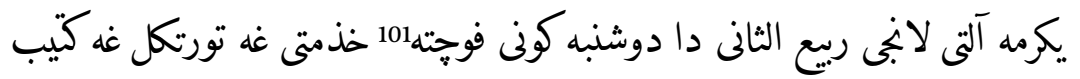

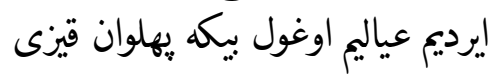
ويوم دا تنها قاليب ايردى يكرمه يتى لابى بيع الثانى دا فوجته ذن تاشلابـ اويوم غه قايتب كيليب قراسام دربازم ايليك دور شولوجه دين قيجقورديم هيج بير خبر اشيتاديم آندين سونكره اوزوم نينكا

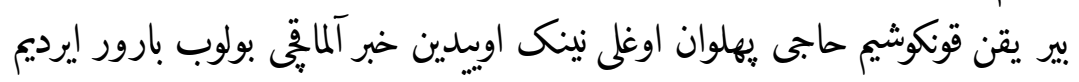
اويوم نينك ياريع طناب اوزاقيده مذكور عياليم نينك اولوكين كورديم آنى فيحهاق ايلان اوروب اولتورلوبدور اوشبونى اولتوركان حاجى يهلوان اوغلى تورور و هم مذكور عياليم ذن قوليده بير يوز إيليك منات تنكه

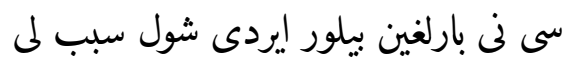
10 آندين كورورمنديب امين آليب باريب مذكور اولوك ذنى جايلابب قايتب كيكان إيركان

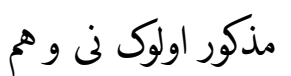
حاجى يهلوان اوغلى نى توغرى سيده آلارنينك عنايت نامه لى اقسقالى ايث محر اقسقال بابانياز اوغلى و جمعه نياز اقسقال ابراهم اوغلى و باباجان اقسقال عبدالله اوغلى و قربان باى اقسقال رحمانبيركان اوغلى و حاجى نياز بالطه نياز

101 Phonetic rendering of the Russian word pochta. 
اوغلى و سلطان باى شيريم اوغلى ويس نياز عبدالله اوغلى و إينياز توره اوغلى و

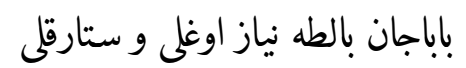

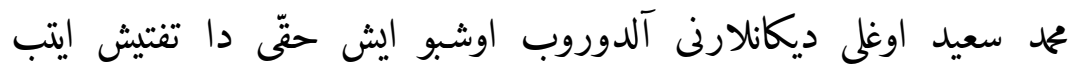

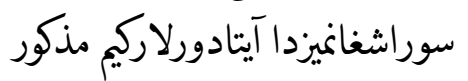
15

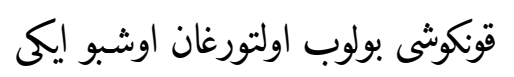

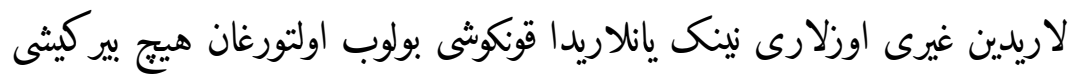
يوقدور بيزلارنينك اولتورغان

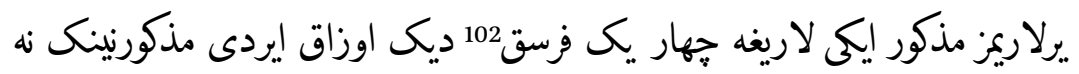
طريقه دا بولوب اولتورولكانى ني بيزلار

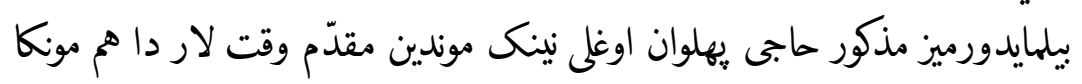
اوخشاش ايشلارغه مباشر بولوب يوركانى نى

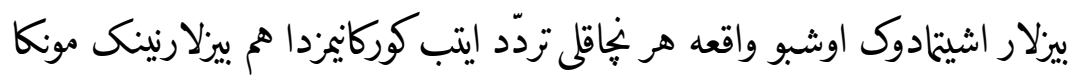
فهميمز يتوشايدور ديب

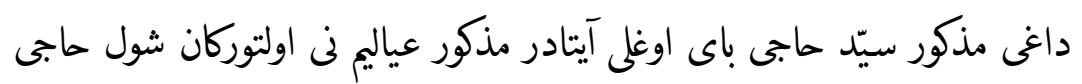

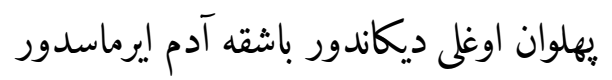

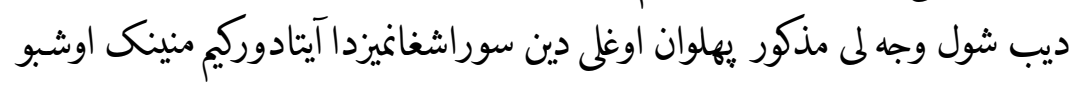

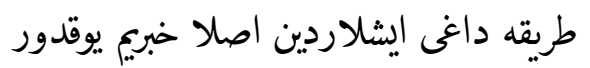
ديب ايمدى مذكور توغريده اقسقال كذا و مدّعى و مدّعى عليه لارنينك تونه سوراشغانميزداغى بيركان اوشبو جوابلارين خذمتلاريغه معلوم قلاميزيكي صورة واقعه اوشبودور ديب اوشبو مكتوب هنبى جمادى الاولدا

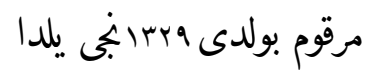

102 Textual variation of فوسخ 
[verso]

سيد بوحته هيى اقرار قلدى حاتونوم اوغول بيكه بنت

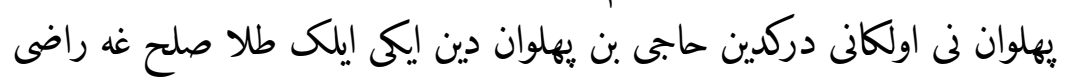
بولدوم ديب ماه جمادى الثانى وبنى سيداكدخد الارى بإباجان اقسقال و ومعه بناز |قسقال و ايش محم اقسقال و قربان باى اقسقال وبrا [no seal] 


\section{Document ${ }_{5}^{6}$}

وزرات يناه حكومت دستكاه يساولباشى آقاميزنينك خذمتلاريغه معروض اولكيم

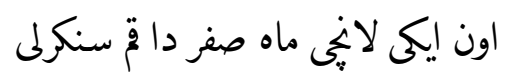

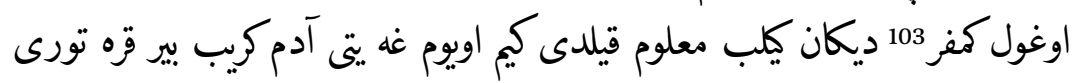

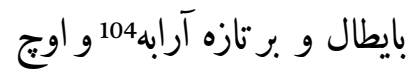
باقتى قوى بر آرجه شونى ايهنده اون آلتى باتمان فُتهن نى تنكه سى اون بيش قداق يفاك تورت يفاك ميسك تورت يادشاهى ايكى يخّى تورت يفاك تون تورت آى رويمال ايكى تورمه ايكى

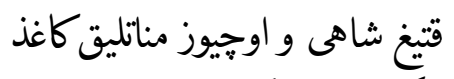
5

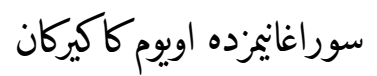

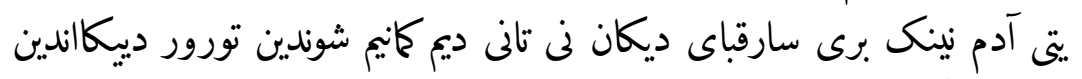

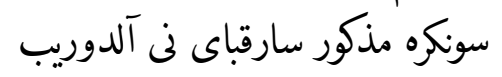

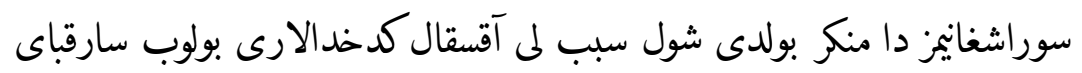
اوغرى ايماس بيشآلتى كون آختاريلسون

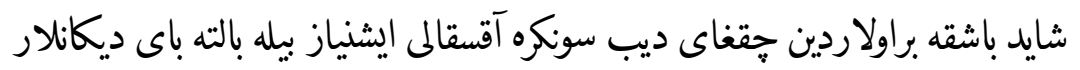
آرياقنى بارلاماق غه بارغال بارغانلاريده صفر قواق ديكان آيغاق بولوب يوز منات آيب آيتوبدور سزلارنى

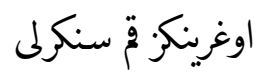

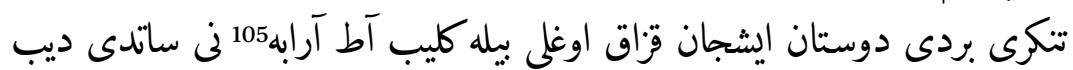
10 بال يحم ديكان ني اويونده اولتورغاينمزده

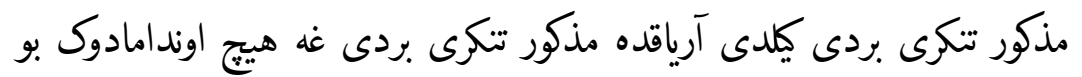

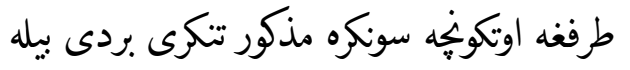

103 Fonetic rendering of كمي

104 sic.

105 sic. 
يولداشى قزاق دستان نى خطاى بازاريده ابراهيم يوزباشى بيله مذكور ايشنياز آقسقال

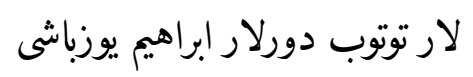

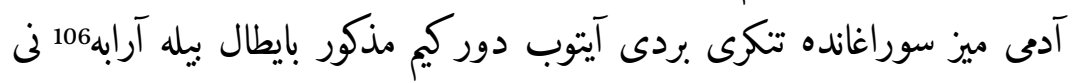
آرياقده عنايت بولوش نى قول آستيده

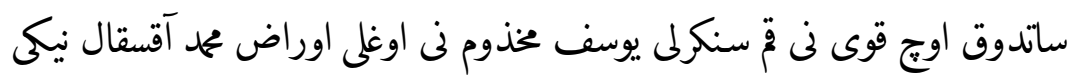
ده سويولدى يولداشلارينك تون

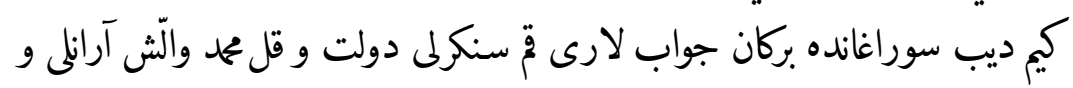
15

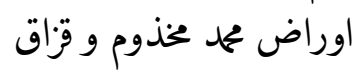
خفر باى ديكان لار تورور ديب مذكور اوغرى لارنى ابراهيم يوزباشى بيله آقسقال

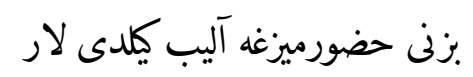

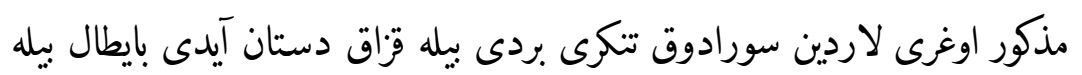

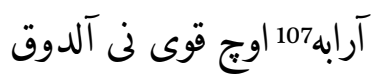
باشقه نمرسه لارين آلغانيمز يوق دور ديب آليدى سونكره مذكور تنكرى بردى بيله دستان ديكان لارنى يولداشيمز

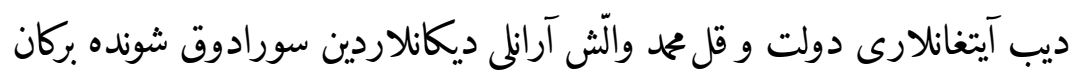
جواب لارى 20 مزلارغه تهمت تورور ليكن مال نى تولا ديسانكيز تولارميز ديب آيديلار و ينه

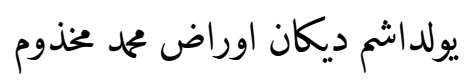

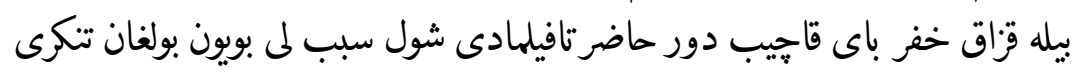

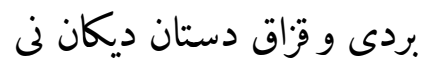

[verso]

ووزم مذكورلارنى يولداشيم ديكان دولت و قل محمد و الش آرانلى ديكانلارنى ابراهيم

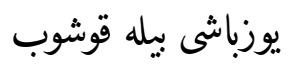

106 sic.

107 sic. 
خذمت لاريغه يباردوك بعده معلوم لارى بولسون كيم مذكور اوغرى لاردين تنكرى بردى ديكان اوجتورت يلدين. بويان يمان اوغرى بولوب هيج تإدورماى آرياقده قاجيب يوركان إيردى اتاسى هم مذكور تنكرى بردى دين

25 بيزار تورور صاحب اختيار دورلار صورة واقعه شول تورور ديب اوشبو عريضه بن دردي نامه

هr لانجى ماه صفر دا مرقوم بولدى arr ابنى يلدا

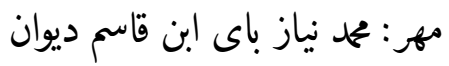


فضيلت نشان يساولباشى آقامز نى خذمتلاريغه معروض بوكم

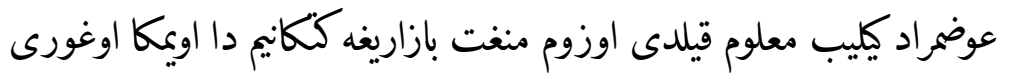

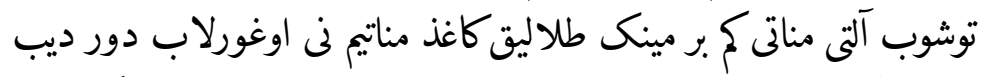

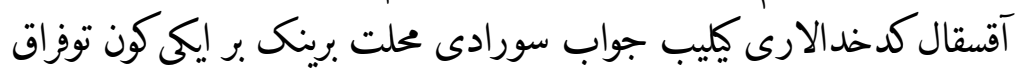

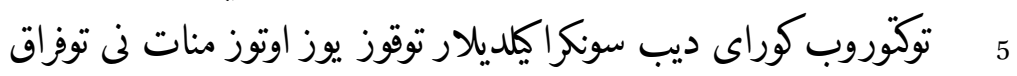

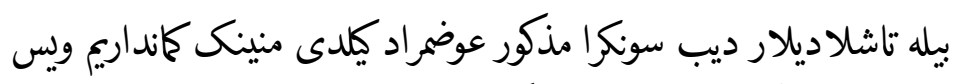

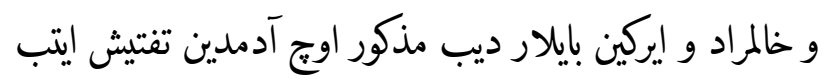

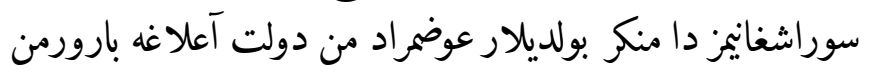

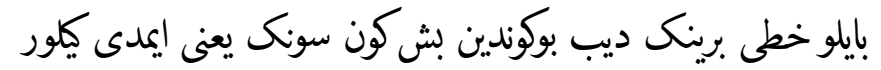
10

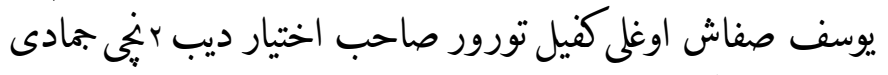

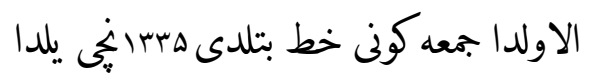
مهر: [※] يوزباشى ابن رمت الله يساولباشى 


\section{Document $5^{8}$}

وزارت يناه و حكومت دستكاه يساول باشى اقاميزنينك خذمتلاريغه معلوم

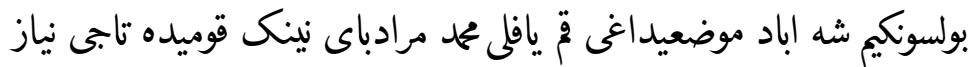

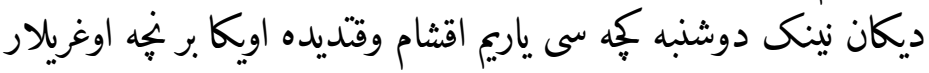

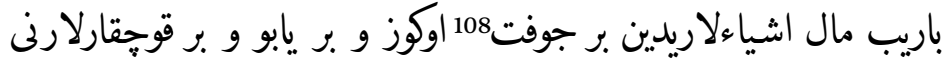
5

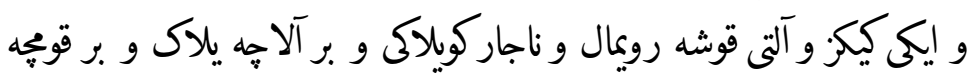

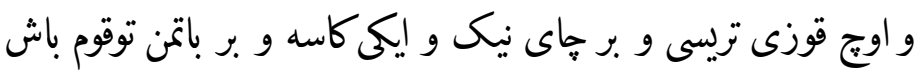

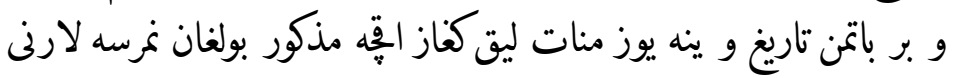

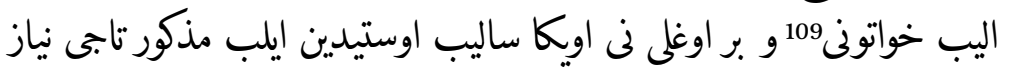
10

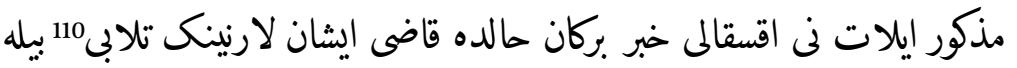

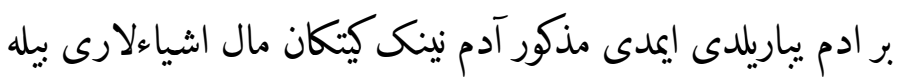
اوزى نينك بولغان واقعه لارينى خذمتلاريغه خط آيب يباريلدى ادئي

[verso]

نى طريقه مهربان بولسه لار اوزلارى بلور ديب ماه رجب نينك 15

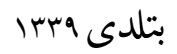
مهر:محمد صفا آتاليق ابن عبدالته آتاليق هبrا

108 Textual variation of جفت

109 Textual variation of جاتون.

110 Textual variation of طلب 


\section{Document 59}

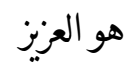

وزارت يناه حكومت دستكاه يساول باشى آقاميزنى جنابلاريغه عرضميز بوكيم

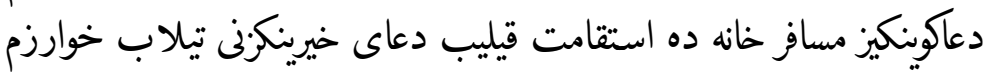

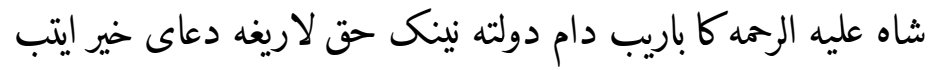
5

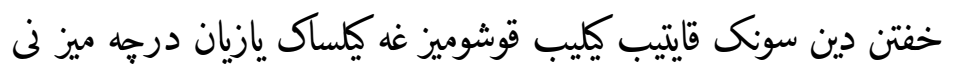

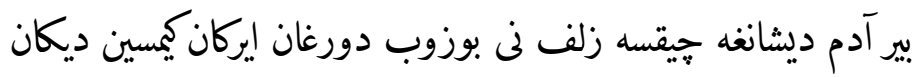

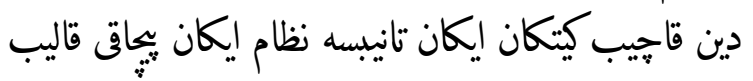

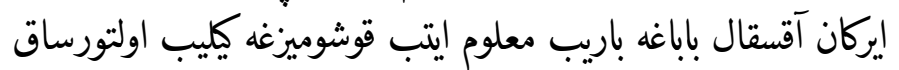
10

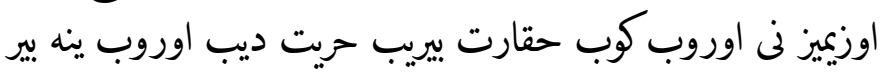

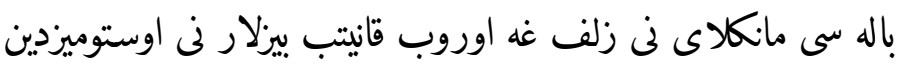

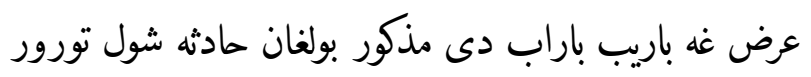
مهر: عبدالله سالم عوضل 


\section{Document 6o}

عزنماب مالا آكتاب يساول باشى اقاميزنينك معلوم لارى بولغايكم طمه لى آدينه

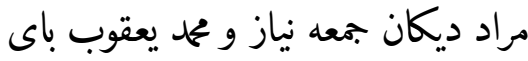

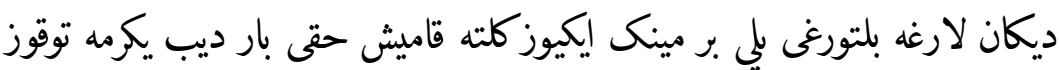
طلا اليب دعواسنى اوتيب خط بريب ايركان و ينه برادرلارى خدائ بردى و محمد شريف ديكانلارغه التى كولته

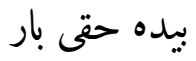
ديب اون بيث طلا اليب خط بريب ايركان ايمدى بو يل ينه شول لارنينك ينه بر بادرى (بادى

5

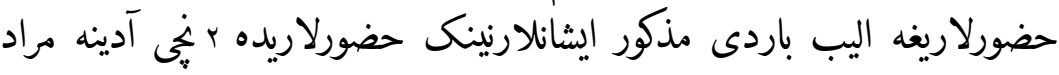

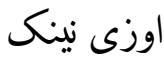
إيلاتى نينك نايب اقسقال كدخدالارى جمع بولوب آدينه مراد مذكور اوزى ناحق توتغويى إنى دعواى قاق تورور ديب اقار بولوب اخبار قلديلار قلندر نايب و باباجان باى و دربيك بابانياز سيد و باباجان باى و مدعًا عليه جمعه نياز و باباجان لارنينك إيلاتى

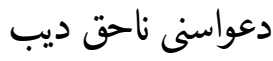
10 باى ديكانلار تورورلار آندين سونكره مذكور خط لارنى كوروب و هم مذكور ادم لار بر نجه دفعه

$$
\text { قسم ايتدى تورولان }
$$
ديب خبر بركانلارى وجهدين ايشان لار مرافعه سنى سوراماديلار ايمدى اوزلارى

$$
\text { بلورلار }
$$

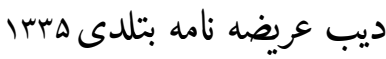

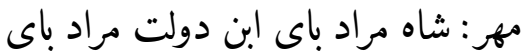




\section{Document 61}

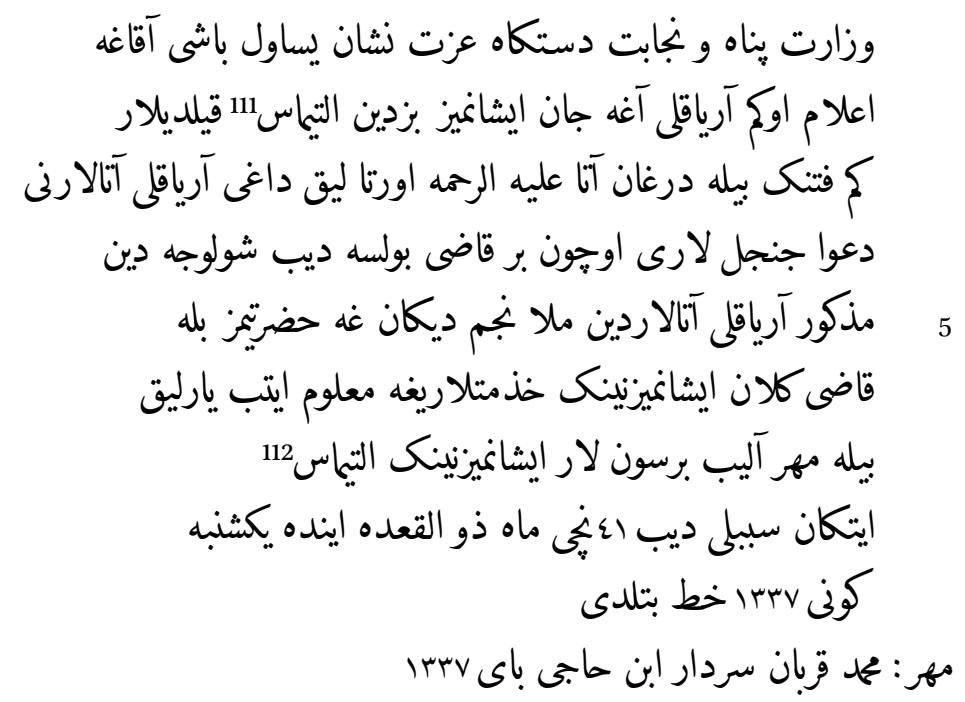

111 Textual variation of التماس.

112 sic. 


\section{Document 62}

قيليج باليل خالياز يوزباشى و صفر محمد نوكارلارنينك حمزه قزاقاق بيله دعوا

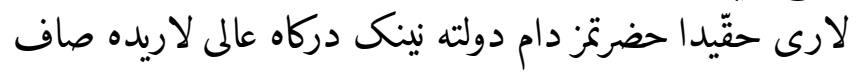

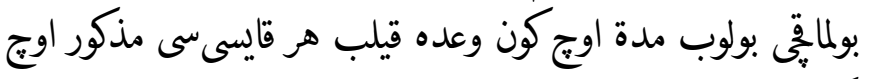

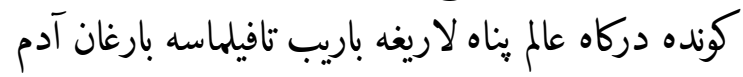

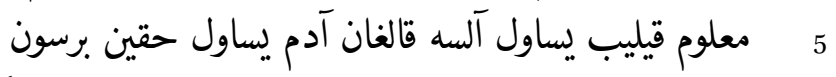

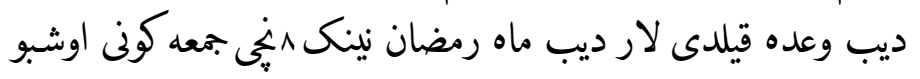

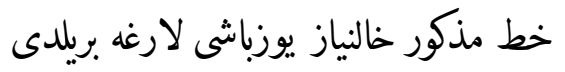
ديب بسبا بتلدى

مهر: محمد لطيف خواجه ابن عبد الكريع جواجه ابسا 


\section{Document 63}

جيان باى قُاق بله قيلج ويكل ديكان قراداشلى نينك بر تيوه اولكان

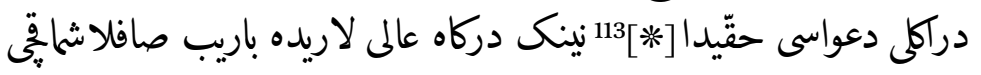
بولوب مدّة بيش كون وعده قيليب مذكور بيش كونده دركاه عالم

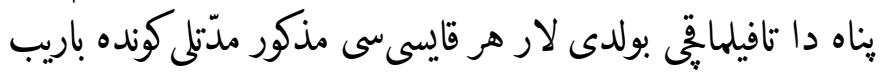
5

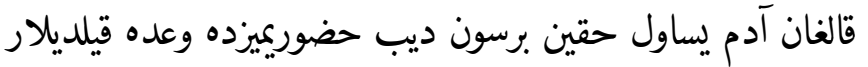

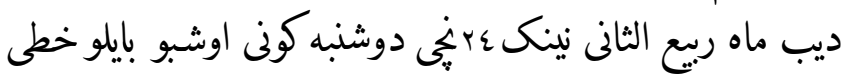

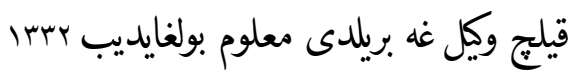

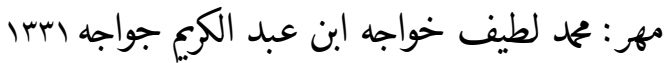

113 Invocation has been missed. 


\section{Document 64}

$$
\text { هو العفو }
$$

حضرت امين السّلطنه و ركن الدّوله محب علها

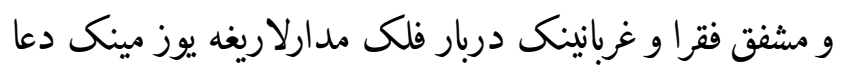

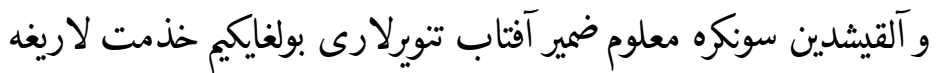
5

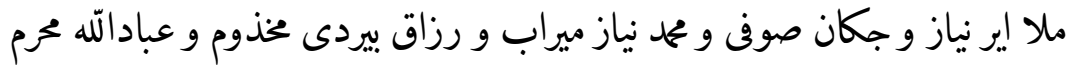

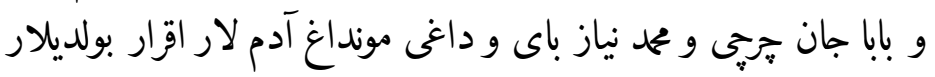
و بولارنينك آيتغانلارينى باور قيلماين نكاح قيلمادوق سيد رضان وضا خواجه ايشان شول خاتون نينك عدّه سى اوتكانغه بيز هم شاهدميز تيديلار آندين 10

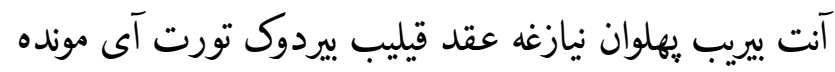
اولتوروب اوركانج غه بارغان إيركان أنينك رئيسلارى هم اويلانيب سين

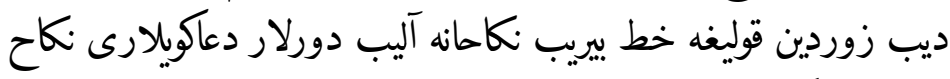

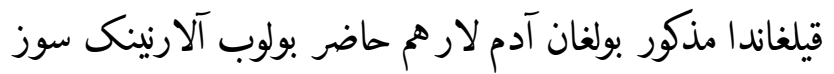

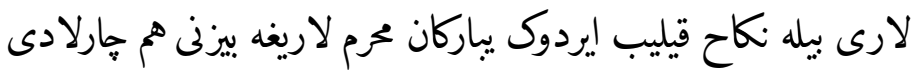

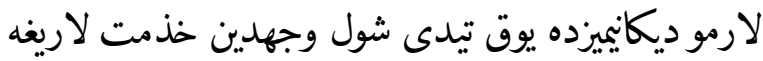

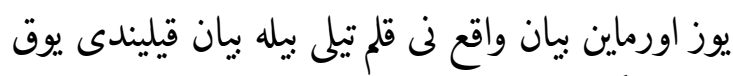

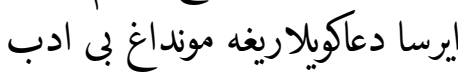
ليكغه قلم اورماقغه نى حد و نو ني يارا 20 و داغى محم رضانينك بيركان الغمانج داغذى صاف بولنى كابلاريغه مناسب كاغذ تايمادى 


$$
\begin{aligned}
& \text { يكرمه دسته مقدارى } \\
& \text { كاغذكرم قيلسالار } \\
& \text { اوزلارى بيلورلار } \\
& \text { و يا هر نهوك كاغذ بلذ } \\
& 30
\end{aligned}
$$

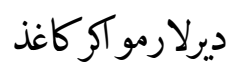

$$
\begin{aligned}
& \text { بيريسا عبازدو\{ الله مخرم } \\
& \text { دعاكويلا ريغه } \\
& \text { قويب راق اولتوروب دوبه } \\
& 35 \\
& \text { تقصير تقصير }
\end{aligned}
$$

مهر: قاضى و رئيس محمود ابن داملا محمكيريم 


\section{Document 65}

قُضّاة اسلام و حكام زوى الاحترام نينك معلوم لارى بولسونكيم

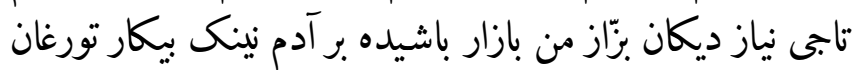

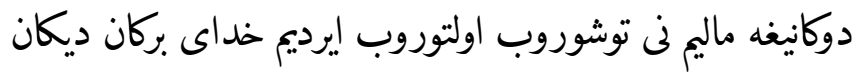

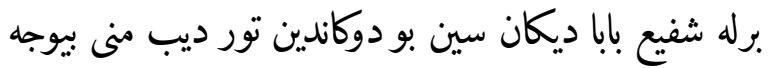

5

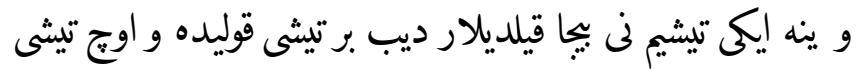

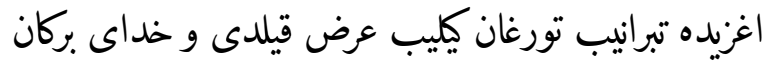

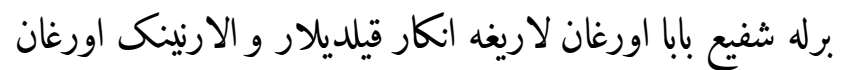

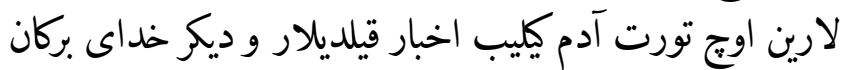

10

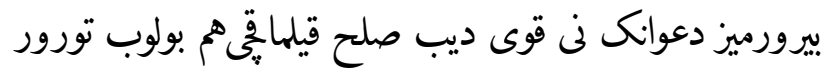

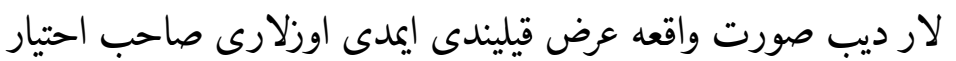

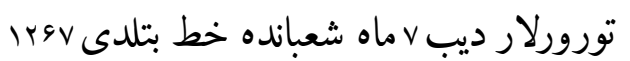
مهر: قاضى و رئيس عبد الغفور [جـ 


\section{Document 66}

نيابت يناه حكومت دستكاه دقيقه شناس رمزرس فلاطون اساس

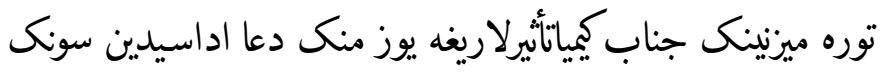

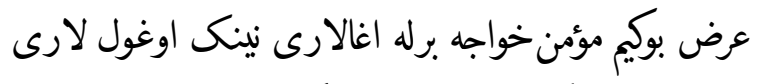

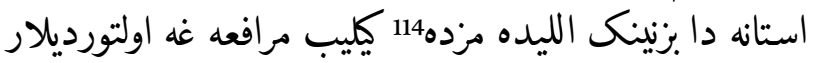
5

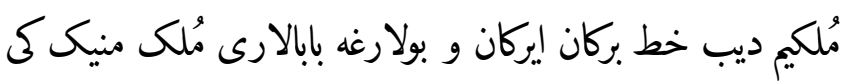

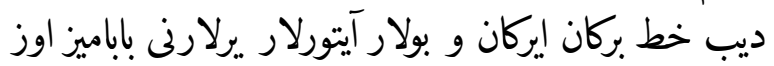

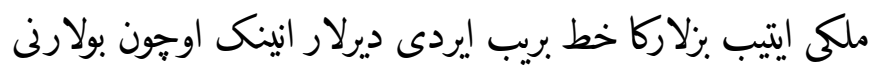

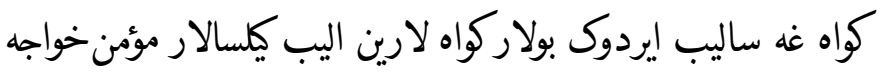
10

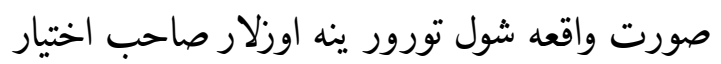

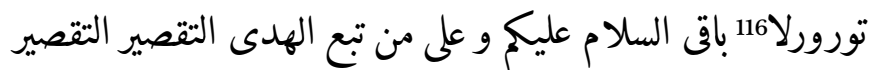

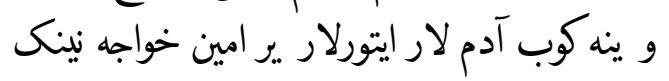
ملكى تورور مهر : قاضى شرع شريف استادكيم عصر و حشيم از حد زياد

114 Clearly: آلديميزكא.

115 sic.

تورورلار 116 


\section{Document 67}

بجناب عالى حضرت اركان دولت رفيع منزلت ستوده خصلت فريشته طينت عده الامدى زبدة الكبرى معين الفقرا ظهر الضعفا مروج دين احدى حامى شريعت مصطفوى الامى باعث الامن و الامان توره بيك ميزينك خذمت لاريغه بو دعاكوى قديم الخذمت لارنينك بصد هزار .

انكسار يوزيدين عرض اخلاص لارى بوكيم بورينجق دوردى ديكانكه نشانه

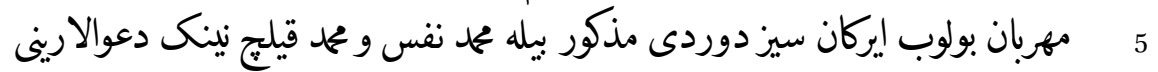

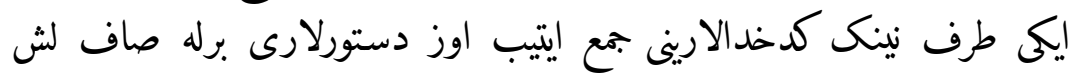
تورسونلار

ديب بجان دل قبول قيلب دوردى مذكوردين محم نقس و مححد قيلج مذكورلارغه

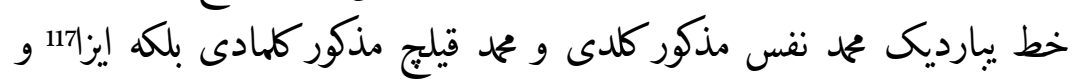
حقارت حط بروب تور ديب ايشتدوك ايمدى سيز صاحب اختيار تورورسيز تقصير. 10 مهر: قاضى جان محم ابن ملا محم دوردى تقير 


\section{Document 68}

خليفه السلطان الاعظم و نايب الخانان المحترم مُحبّ العلهأ مشفق الفقراءغه

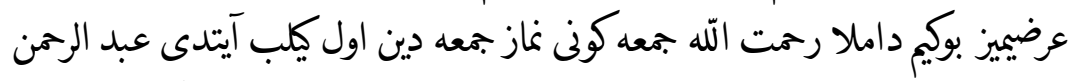
ديكان وقف نينك غلّه سى اوهون بارغانده بيزنى اوردى و اينسى سوكدى اندين

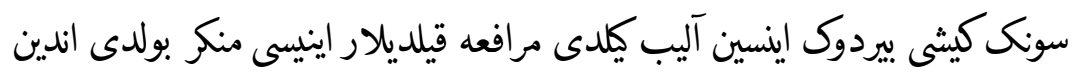

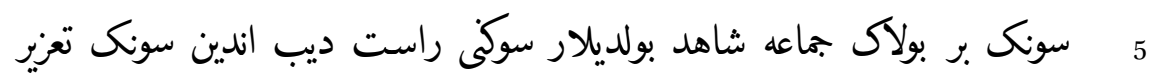
قيلدوق آلتى تعزير اورغانده ملا مذكورنينك اوزى تيلاب آلدى اندين سونك خفتن وقتيده عبد الرمن مذكور حاضر بولدى ملا مذكور بيلان مرافعه قيلجق بولوب بز آيتدوق ماند !يرتنك كيكونك ديب شنبه كونى إيتتك نماز وقتيده عبد الرحمن مذكور كيلدى اقشام قايتب

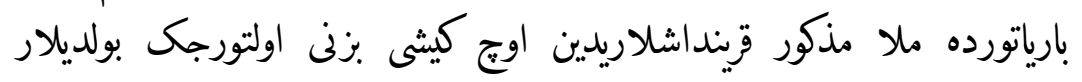
بازارجيلار 10 ايتدوق حقارت دعواسى صافلاشسون اندين سوزك كيتارسز ديدوك ملا مذكور يمكانهه توقف حتف قيلسون ملا مذكزر كيلمس دين بورون سرزكا عرض توض

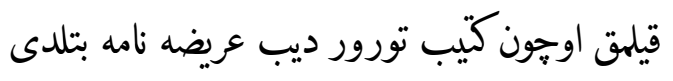

مهر: قاضى [ج] 


\section{Document 69}

حضرتميز دام دولته [*ت] حضرت خليفه الرحان ظل السبحان اسكندرنشان قيصرياسبان

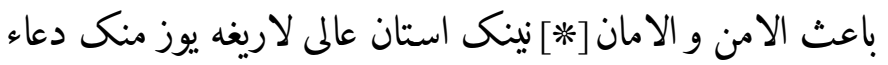

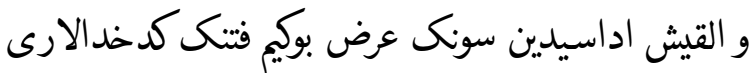

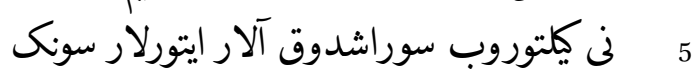

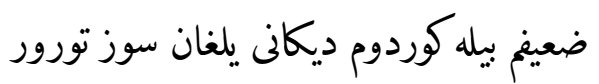

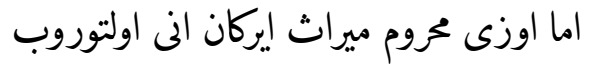

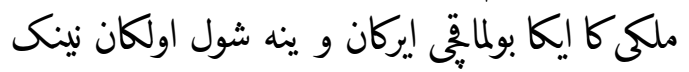

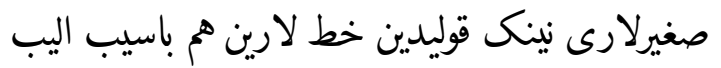
10

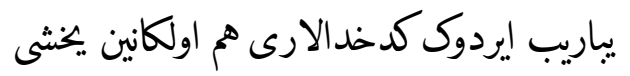
راق كورارلار ينه اوزلارى صاحب اختيار تورور

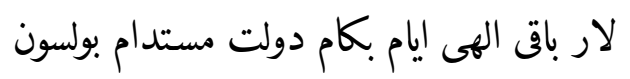

$[\%]:$ مر 


\section{Document 70}

$$
\begin{aligned}
& \text { تورهبيكيمزيك جناب عاليلا ريغه عرضلا ريمز بوكمقرهوفهلى } \\
& \text { فقرألارخذ متيكزنه عرض ايتكان ايركانلار بزنيك } \\
& \text { اوستى ميزكاعرب طايفه سقى قتلى مرادديكان آدمنى } \\
& \text { يساول ديبكيلتوروب عبد الرحيمصوفيدي ديكان } \\
& 5
\end{aligned}
$$

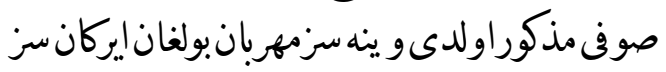

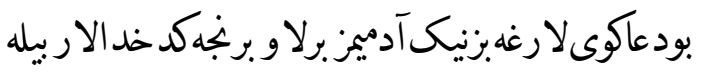

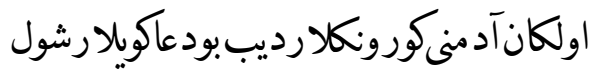

$$
\begin{aligned}
& \text { موضعكدخد الارى برلا اولوكىكوردى ارقه سيده } \\
& 10 \\
& \text { شونجالىتورورايمدى اوزلارى صاحبارياختيار } \\
& \text { تورورواضحباد السلام السلام السلا معليكي }
\end{aligned}
$$




\section{Document 71}

دعاى سلا مبلا نهايه و بلا غايه زاده عمره ومسنده توره بيكيمزك بعده مخفى قالماسون بويورغان. امرلا رين مهما امكن (؟) قولميزدينيكاكانيحه قيلدوق شول ميت نينك برى آت سقال ليق

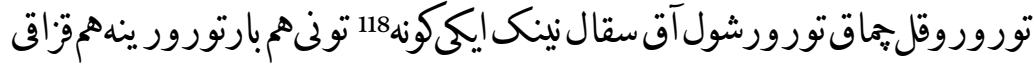

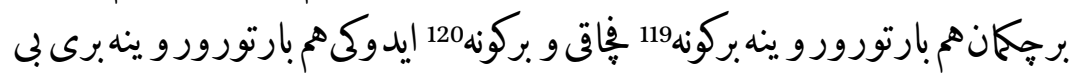

سقال

5 يكيت توروراوجتونىبار برىقيزيلو ينه برى آقبالقى ينه بركهنهتونىبارتورور

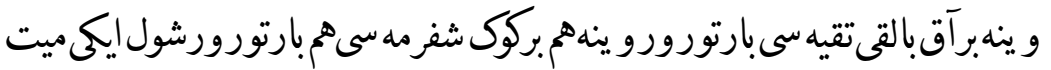
نينك ياتغانيرلارى خان حضرت ميزنينك يرلارى تورورو ينه شول ميت لارنينيك ياتغان

يرلارى راه عامه توروراطرافلا رينده قانهم يوق تورورو ينه ميانه ميت مذكور.

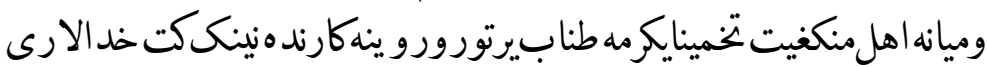

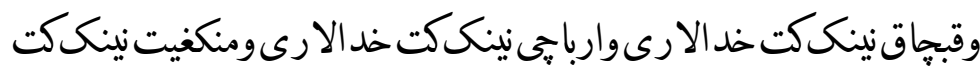
10

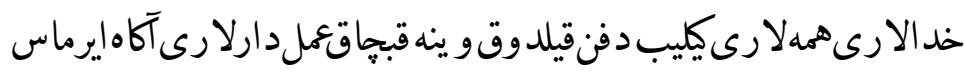

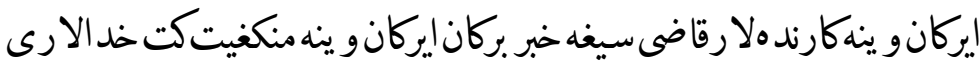
هم ايشيت كان ايرماس ايركان

118 Textual variation of كوهن.

119 sic.

120 sic. 


\section{Document 72}

حضرتميز دام دولته [ حمثنة

خليغه الرحمن ظل السبحان [**] نينك استان فلك مدارهـ مدارلاريغه تومان منك دعاء ارساليدين سونك عرض بوكيم خاصه بوينده بر آدم اوز ضعيفه سينى اورب اولتوروب حضرت شاه بابانينك 5 مزاراتى نينك بر طرفيغه كيلتوروب تاشلابدوروكدخدا

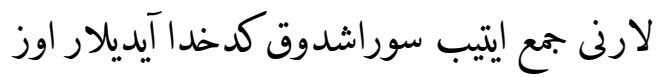
كياوى اولتوروب تاشلابدور انديب سوراشدوف دين سونك شول

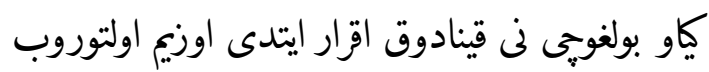
ايلتيب تاشلاديم ديدى حتى كدخدالارى هم ايتورلار 10 قوتولوب جيقسه بزلار همه ميزنى كوجورور ديرلار ينه اوزلارى صاحب اختيار تورور ديب عرضه داشت ايتلدى مئى باقى ايام بكام دولت مستدام بولغاى آمين و رب دولي العالمين و ينه عرض بائ 15 ضعيفه نينك هيج

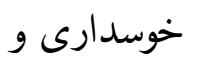
كيشى ايرى هم يوق اصلأ

مهر: [\% 


\section{Document 73}

عريضه داشت اداسيدين سونكره حضرت توره بيكميزنينك الإنيك

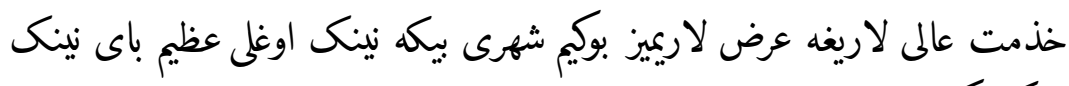

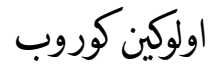
هر نه اعضاسيده جراحت و داغ و ونشانه سى بولسه كوروب جنازه سين

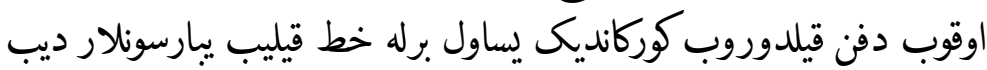

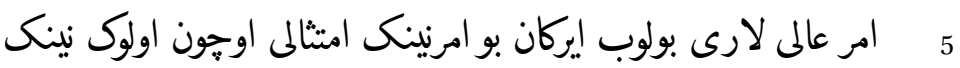

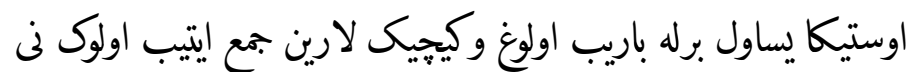

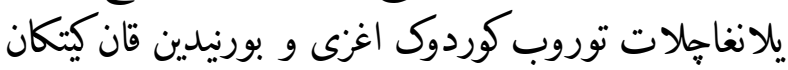

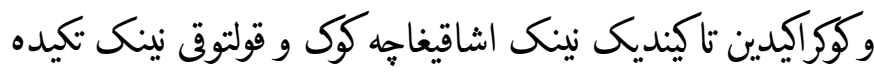

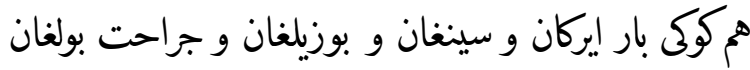
10

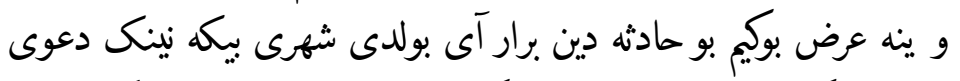

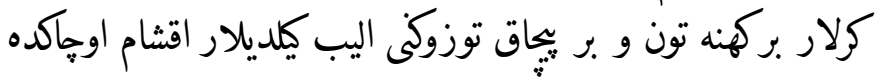

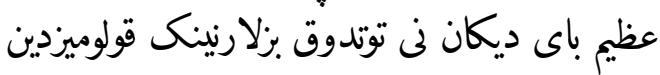

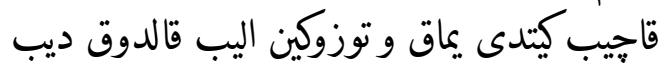
15 عرض قيلندى ايمدى اوزلارى صاحب اختيار تورورلار اليدار التقصير التقصير التقصير

[*] مهر 